Integração de dados na inferência de redes de genes: avaliação de informações biológicas e características topológicas

Fábio Fernandes da Rocha Vicente

TESE APRESENTADA

$\mathrm{AO}$

Programa Interunidades EM Bioinformática

DA

Universidade De SÃo PaUlo

PARA

OBTENÇÃO DO TÍTULO

$\mathrm{DE}$

Doutor EM CIÊNCIAS

\author{
Programa: Doutorado em Bioinformática \\ Orientador: Prof. Dr. Fabrício Martins Lopes
}

Durante o desenvolvimento deste trabalho o autor recebeu auxílio financeiro da UTFPR/CAPES/CNPq/FAPESP/Fundação Araucária

São Paulo, maio de 2016 



\title{
Integração de dados na inferência de redes de genes: avaliação de informações biológicas e características topológicas
}

\author{
Esta versão da tese contém as correções e alterações sugeridas \\ pela Comissão Julgadora durante a defesa da versão original do trabalho, \\ realizada em 02 de maio de 2016. Uma cópia da versão original está disponível no \\ Instituto de Matemática e Estatística da Universidade de São Paulo.
}

Comissão Julgadora:

- Prof. Dr. Fabrício Martins Lopes - UTFPR

- Prof. Dr. Alexandre dos Santos Cristino - UQ

- Prof. Dr. David Corrêa Martins Junior - UFABC

- Prof. Dr. Hugo Aguirre Armelin - IQ-USP

- Prof. Dr. Junior Barrera - IME-USP 

"O semicientista não é quem só sabe metade das coisas, é aquele que só as sabe pela metade. Saibam o que decidiram saber e deem uma olhada no restante. O que não pertencer a sua vocação própria, entreguem-no a Deus que disso cuidará. Não sejam desertores de si mesmos, por ter querido substituir-se a todos."

A-D. Sertillanges 

Aos meus amados pais Antonio (in memoriam) e Ana e a minha irmã Lilian. 



\section{Agradecimentos}

Em primeiro lugar, agradeço a Deus por ter me dado vida, saúde, ânimo, persistência e inspiração para a realização deste trabalho.

Agradeço a meus pais, Antonio e Ana, pela educação que me deram, pelo carinho e por todo incentivo.

À minha irmã, Lilian, pelo incentivo, carinho e companheirismo em todos os momentos.

Ao Fabrício Martins Lopes, pela confiança, por aceitar me orientar no doutorado e por todo incentivo. Seu conhecimento e suas boas idéias contribuíram muito com o trabalho. Também não posso deixar de dizer que sua maneira positiva e focada de lidar com as situações contribuíram muito com minha formação.

Aos professores que participaram diretamente na escrita dos artigos, por meio de ideias, críticas, sugestões e revisões: Roberto Marcondes Cesar Jr e Ronaldo Fumio Hashimoto.

Às demais pessoas que colaboraram com esta pesquisa: Euler Menezes, Gabriel Rubino e Juliana Oliveira e, em particular, ao professor Junior Barrera pelas importantes críticas e direcionamentos e ao professor David Corrêa Martins Junior por ceder alguns dados e também pelas críticas ao trabalho.

Aos amigos André Yoshiaki Kashiwabara e Alexandre Paschoal especialmente pela amizade e companheirismo. Agradeço também pelas substituições de aulas na UTFPR nos momentos que necessitei.

Aos amigos Jihan Zoghbi e Silvio de Faria pela ajuda e acolhida quando necessitei de acesso ao laboratório.

Aos meus ex-professores Ronei Ximenes Martins e Luiz Eduardo da Silva que me instruíram e incentivaram na iniciação da carreira de pesquisa durante a Faculdade.

À minha ex-professora e amiga Hélia Cardoso Gomes da Rocha pelos incontáveis bons conselhos e orientações sobre a carreira acadêmica.

Aos amigos e companheiros de estudo e de laboratório: Alessandra Vanessa, Alessandro Jaquiel Waclawovsky, Carlos Hotta, Carolina Gimiliani Lembke, Erica Michelle, Luciana Mantzouranis, Maximiller Dal-Bianco Lamas Costa, Milton Yutaka Nishiyama Junior e Savio Siqueira, pelos momentos alegres, pelas conversas informais e discussões sobre assuntos importantes.

Ao amigo Artur Trancoso Lopo Lopo de Queiroz pelo incentivo e pela pimenta baiana.

Aos membros da CPG-Bioinfo pelos encaminhamentos e pela oportunidade de aprendizado quando participei como representante discente. Também agradeço pela oportunidade dada de participar da organização de um dos cursos de verão.

Ao professor Alan Mitchell Durham pelo incentivo, orientações e conselhos em decisões importantes.

À Patrícia Martorelli e à Cristiane por toda ajuda com as questões técnicas e burocráticas. 
Aos amigos da UTFPR pelo apoio em possibilitar um afastamento por um ano que foi muito importante para o desenvolvimento do trabalho.

À CAPES, CNPq, FAPESP grant 2011/50761-2, NAP eScience - PRP - USP, Fundação Araucária e UTFPR pelo apoio financeiro e acesso a estrutura computacional. 


\section{Resumo}

Os componentes celulares não atuam sozinhos, mas sim em uma rede de interações. Neste sentido, é fundamental descobrir como os genes se relacionam e compreender a dinâmica do sistema biológico. Este conhecimento pode contribuir para o tratamento de doenças, para o melhoramento genético de plantas e aumento de produção agrícola, por exemplo. Muitas redes gênicas são desconhecidas ou apenas conhecidas parcialmente. Neste contexto, a inferência de Redes Gênicas surgiu como possível solução e tem por objetivo recuperar a rede a partir de dados de expressão gênica utilizando modelos probabilísticos. No entanto, um problema intrínseco da inferência de redes é formalmente descrito como "maldição da dimensionalidade" (a quantidade de variáveis é muito maior que a quantidade de amostras). No contexto biológico, este problema é ainda agravado pois é necessário lidar com milhares de genes e apenas um ou duas dezenas de amostras de dados de expressão. Assim, os modelos de inferência buscam contornar este problema propondo soluções que minimizem o erro de estimação. Nos modelos de predição ainda há muitos empates, isto é, apenas os dados de expressão não são suficientes para decidir pela interação correta entre os genes. Neste contexto, a proposta de integração de outros dados biológicos além do dado de expressão gênica surge como possível solução. No entanto, estes dados são heterogêneos: referem-se a interações físicas, relacionamentos funcionais, localização, dentre outros. Além disto são representados de diferentes formas: como dado quantitativo, qualitativo, como atributos nominais ou atributos ordinais. Algumas vezes organizados em estrutura hierárquica, em outras como um grafo e ainda como anotação descritiva. Além disto, não está claro como cada tipo de dado pode contribuir com a inferência e redução do erro dos modelos. Portanto, é fundamental buscar compreender a relação entre os dados biológicos disponíveis, bem como investigar como integrá-los na inferência. Assim, neste trabalho desenvolveu-se três metodologias de integração de dados e a contribuição de cada tipo foi analisada. Os resultados mostraram que o uso conjunto de dados de expressão e outros dados biológicos melhora a predição das redes. Também apontaram para diferença no potencial de redução do erro de acordo com o tipo de dado. Além disto, os resultados mostraram que o conhecimento da topologia da rede também reduz o erro além de inferir redes topologicamente coerentes com a topologia esperada. Palavras-chave: redes de genes, integração de dados, bioinformática, reconhecimento de padrões, redes complexas. 



\section{Abstract}

It is widely known that the cellular components do not act in isolation but through a network of interactions. In this sense, it is essential to discover how genes interact with each other and to understand the dynamics of the biological system. This knowledge can contribute for the treatment of diseases, contribute for plant breeding and increased agricultural production. In this context, the inference of Gene Networks (GNs) has emerged as a possible solution, studying how to recover the network from gene expression data through probabilistic models. However, a known problem of network inference is formally described as "curse of dimensionality " (the number of variables is much larger than the number of samples). In biological problems, it is even worse since there is only few samples and thousands of genes. However, there are still many "ties" found in the prediction models, that is, only the expression data are frequently not enough to decide the correct interaction between genes. In this context, data integration is proposed as a possible solution. However, the data are heterogeneous, refer to physical interactions and functional location. They are represented in different ways as quantitative or qualitative information, being nominal or ordinal attributes. Sometimes organized in hierarchical structure or as a graph. In addition, it is unclear how each type of data can contribute to the inference and reduction of the error. Therefore, it is very important to understand the relationship between the biological information available. Also, it is important to investigate how to integrate them in the inference algorithm. Thus, this work has developed three data integration methodologies and also, the contribution of biological information was analyzed. The results showed that the combined use of expression data and biological information improves the inference. Moreover, the results shows distinct behaviour of distinct data in error reduction. Also, experiments that include topological features into the models, shows that the knowledge of the network topology can increase the corrctness of the inferred newtorks.

Keywords: gene networks, data integration, bioinformatics, pattern recognition, complex networks. 



\section{Sumário}

Lista de Abreviaturas $\quad$ xiv

Lista de Símbolos $\quad$ xvi

Lista de Figuras $\quad$ xvii

Lista de Tabelas $\quad$ xx

1 Introdução $\quad 1$

1.1 Motivação . . . . . . . . . . . . . . . . . . . . . . . . . . . . . 1

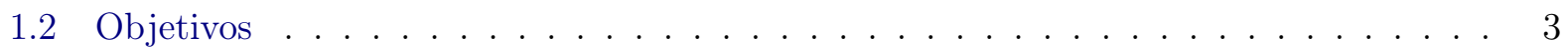

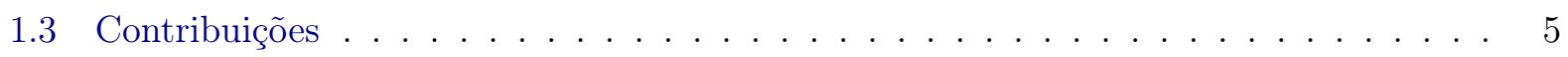

1.4 Organização do trabalho . . . . . . . . . . . . . . . . . . . 6

$\begin{array}{lll}2 & \text { Revisão Bibliográfica } & 7\end{array}$

2.1 Biologia Sistêmica . . . . . . . . . . . . . . . . . 7

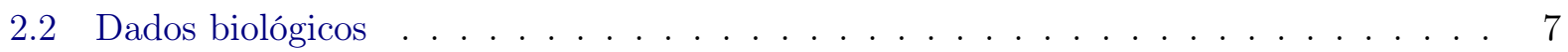

2.2 .1 Dados de expressão gênica . . . . . . . . . . . . . . . . . . . 7

2.2.2 PPI - Interação proteína-proteína . . . . . . . . . . . . . . . . 8

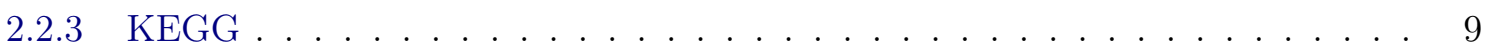

2.2 .4 Gene Ontology . . . . . . . . . . . . . . . . . . . . . . . . . 10

2.2 .5 Rosetta Stone Fusion Proteins . . . . . . . . . . . . . . . . . . . . . 10

2.3 Representação das Redes Gênicas . . . . . . . . . . . . . . . . . . . . . . 10

2.4 Modelagem de Redes Gênicas . . . . . . . . . . . . . . . . . . . . . . . . 12

2.4.1 Redes Booleanas . . . . . . . . . . . . . . . . . . . . . . 12

2.4 .2 Redes Booleanas Probabilísticas - PBNs . . . . . . . . . . . . . . . 14

2.4 .3 Redes Gênicas Probabilísticas - PGNs . . . . . . . . . . . . . . . . 16

2.5 Seleção de Características, Busca e Função Critério . . . . . . . . . . . . . . . . . . 17

2.5.1 SFS - Sequential Forward Selection . . . . . . . . . . . . . . . 19

2.5.2 SBS - Sequential Backward Selection . . . . . . . . . . . . . . . . . 19

2.5.3 SFFS - Sequential Forward Floating Selection . . . . . . . . . . . . . . . . . 19

2.6 Inferência de Redes . . . . . . . . . . . . . . . . . . . . . . . . . 19

2.6 .1 Correlação . . . . . . . . . . . . . . . . . . . . . . 20

2.6 .2 Coeficiente de Determinação . . . . . . . . . . . . . . . . . . . 21

2.6.3 Teoria da Informação: Entropia e Informação Mútua . . . . . . . . . . . . . . . 21

2.7 Redes complexas e características topológicas . . . . . . . . . . . . . 23 
2.7 .1 Caracterização e representação . . . . . . . . . . . . . . . . . . . . 24

2.7 .2 Redes Small-World . . . . . . . . . . . . . . . . . . . . . . 25

2.8 Integração de dados . . . . . . . . . . . . . . . . . . . . 26

2.8 .1 Escore Biológico . . . . . . . . . . . . . . . . . . . 27

2.8.2 Independência entre informações biológicas . . . . . . . . . . . . . . . 28

2.8.3 Dados de expressão e medidas de correlação . . . . . . . . . . . . . . 28

2.8.4 Heterogeneidade dos dados . . . . . . . . . . . . . . . . . 28

3 Materiais e Métodos $\quad 30$

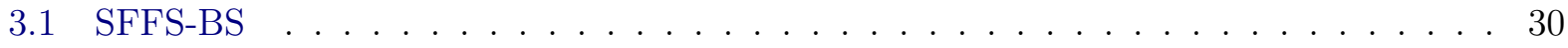

3.1.1 Algoritmo de inferência . . . . . . . . . . . . . . . . . . . 30

3.1 .2 Dados de expressão . . . . . . . . . . . . . . . . . . . . . . 32

3.1.3 Dado de rede de interação proteína-proteína - PPI . . . . . . . . . . . . . . . 32

3.1.4 Dado Rosetta Stone Fusion Proteins . . . . . . . . . . . . . . . . . . . . . 33

3.1 .5 Dado de KEGG . . . . . . . . . . . . . . . . . . . . . . . . . . . 34

3.1 .6 Dado de KEGG mais GO . . . . . . . . . . . . . . . . . . . . . 34

3.1 .7 Interseção entre os conjuntos de dados . . . . . . . . . . . . . . . . . . . . 35

3.1 .8 Metodologia de avaliação . . . . . . . . . . . . . . . . . . . 35

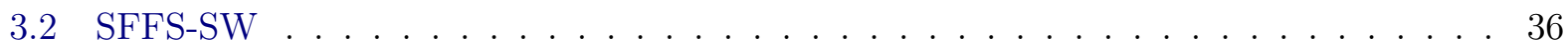

3.2 .1 Redes Small World de Watts e Strogatz . . . . . . . . . . . . . . . 36

3.2.2 Extração de características da GN . . . . . . . . . . . . . . . . . . . 37

3.2 .3 Algoritmo de seleção de características: SFFS-SW . . . . . . . . . . . . . . 38

3.2.4 Metodologia de avaliação . . . . . . . . . . . . . . . . . . . . . . 39

3.3 Integração de dados e inferência de redes em Arabidopsis thaliana . . . . . . . . . . . 40

3.3.1 Função critério . . . . . . . . . . . . . . . . . . . . . . . . . . . . 40

3.3.2 Rede gold standard . . . . . . . . . . . . . . . . . . . . . . . . . 40

3.3.3 Dados de expressão . . . . . . . . . . . . . . . . . . . . . . . . . . . . . . 40

3.3.4 Informação biológica de Arabidopsis thaliana . . . . . . . . . . . . . . . 41

3.3.5 Avaliação do método . . . . . . . . . . . . . . . . . . . . . . . . . . 41

4 Resultados $\quad 42$

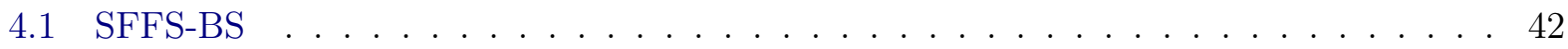

4.1 .1 Dados de PPI . . . . . . . . . . . . . . . . . . . . . . . 42

4.1 .2 Rosetta Stone e KEGG . . . . . . . . . . . . . . . . . . . . . . 44

4.1 .3 Genes HUB . . . . . . . . . . . . . . . . . . . . . . . 45

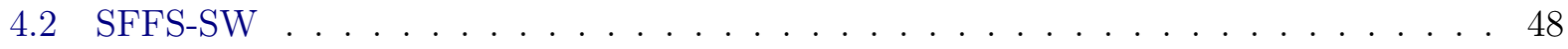

4.2.1 Avaliação da similaridade, precisão e sensibilidade do método . . . . . . . . . 48

4.2 .2 Avaliação da trajetória das medidas de caracterização . . . . . . . . . . . . 50

4.3 Integração de dados em Arabidopsis thaliana . . . . . . . . . . . . . . . . . . . . . 52

4.3.1 Conjunto de dados de validação . . . . . . . . . . . . . . . . . . . . 52

4.3 .2 Avaliação dos resultados . . . . . . . . . . . . . . . . . . . . . . . . 53 
5 Conclusão e trabalhos futuros $\quad 55$

5.1 SFFS-BS e dado biológico . . . . . . . . . . . . . . . . . 55

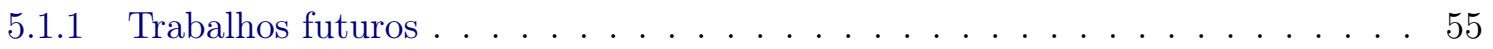

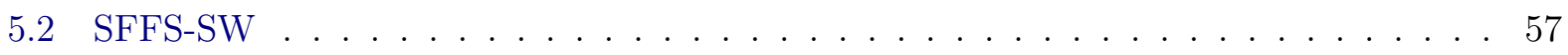

5.2 .1 Trabalhos futuros . . . . . . . . . . . . . . . . . . 57

5.3 Inferência de redes em Arabidopsis thaliana . . . . . . . . . . . . . 58

5.3.1 Trabalhos futuros: atribuição automática de pesos . . . . . . . . . . . . 59

5.4 Múltiplas hipóteses e múltiplas evidências . . . . . . . . . . . . . . . . . 59

5.4 .1 Visão geral do modelo . . . . . . . . . . . . . . . . . . . . 59

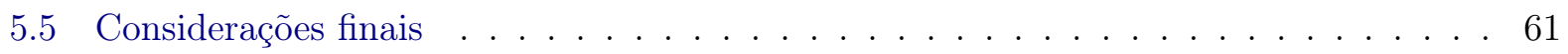

$\begin{array}{llr}6 & \text { Artigos publicados } & 62\end{array}$

$\begin{array}{ll}\text { Referências Bibliográficas } & 63\end{array}$

$\begin{array}{ll}\text { Índice Remissivo } & 75\end{array}$ 


\title{
Lista de Abreviaturas
}

\author{
BS Escore biológico (Biological Score) \\ BN Redes Booleanas (Boolean Networks) \\ CoD Coeficiente de Determinação (Coefficient of Determination) \\ cDNA DNA complementar \\ DAG Grafo Acíclico Dirigido (Directed Acyclic Graph) \\ DNA Ácido Desoxirribonucleico (deoxyribonucleic acid) \\ FP Falso Positivo (False Positive) \\ FN Falso Negativo (False Negative) \\ GO Banco de dados de Ontologia de Genes (Gene Ontology) \\ GN Rede Gênica (Gene Network) \\ GSP Processamento de Sinal Genômico (Genomic Signal Processing) \\ IGSi i-ésimo conjunto de interseção entre conjunto dados de validação (Intersection Gold Standard i) \\ KEGG Kyoto Encyclopedia of Genes and Genomes \\ KNN Algoritmo dos $\mathrm{k}$ vizinhos (k-nearest neighbors algorithm) \\ mRNA RNA mensageiro (messenger RNA) \\ MCE Entropia Condicional Média (Mean Conditional Entropy) \\ MCE-SW Entropia Condicional Média e topologia Small World (função critério) \\ MIPS Munich Information Center for Protein Sequences \\ PBN Redes Booleanas Probabilísticas (Probabilistic Boolean Networks) \\ PGN Redes Gênicas Probabilística (Probabilistic Genetic Networks) \\ PPI Rede de Interação Proteína-proteína (Protein-protein Interaction Network) \\ PPV Valor de Predição Positivo (Positive Predictive Value) \\ PSSM Position Specific Scoring Matrix \\ RNA Ácido Ribonucleico (ribonucleic acid)) \\ SAGE Serial Analysis of Gene Expression \\ SBS Busca sequencial para trás (Sequential Backward Selection) \\ SFS Busca sequencial para frente (Sequential Forward Selection) \\ SFFS Busca sequencial flutuante (Sequential Forward Floating Selection) \\ SFFS-BS Algoritmo SFFS com Escore Biológico (SFFS and Biological Score) \\ SFFS-SW Algoritmo SFFS com topologia de redes Small World \\ SW Rede Small World \\ TF (Transcription Factor) \\ TFBS Sítio de Ligação de Fator de Transcrição (Transcription Factor Binding Site) \\ TN Verdadeiro Negativo (True Negative) \\ TP Verdadeiro Positivo (True Positive) \\ Y2H Sistema de duplo-híbrido em levedura (Yeast two hybrid)
}




\section{Lista de Símbolos}

$\begin{array}{ll}B S_{x, y} & \text { Escore biológico entre as variáveis } x \text { e } y \\ C o D(X, Y) & \text { Coeficiente de Determinação de } X \text { e } Y \\ D_{x, y}^{i} & \text { i-ésima fonte de dados biológicos sobre os genes } x \text { e } y \\ w_{1} & \text { Peso do dado de expressão } \\ w_{2} & \text { Peso do dado biológico } \\ g(t) & \text { Valor da expressão do gene no tempo } t \\ E[g(t)] & \text { Valor Esperado de } g(t) \\ H_{B G} & \text { Entropia de Boltzmann-Gibbs } \\ H(X) & \text { Entropia de } X \\ H(Y \mid x) & \text { Entropia condicional de } Y \text { dado a instância } x \\ H(Y \mid X) & \text { Entropia Condicional Média de } Y \text { dado cada instância de } X \\ H(X, Y) & \text { Entropia conjunta de duas variáveis } X \text { e } Y \\ M C E-S W & \text { Função Critério baseada em MCE e características topológicas de redes Small World } \\ M(X, Y) & \text { Informação Mútua das variáveis aleatórias } X \text { e } Y \\ \epsilon(Y, \mathbf{X}) & \text { Erro quadrático médio mínimo de um preditor } f(\mathbf{X}) \text { de } Y \\ \epsilon_{0}(Y) & \text { Erro do melhor estimador de } Y \text { na ausência de variáveis condicionais } \\ \eta[g(t)] & \text { Normalização do sinal do gene no instante } t \\ \gamma & \text { Peso do dado de expressão na função critério } \\ \sigma & \text { Desvio padrão } \\ \Upsilon & \text { Função de transição da PBN }\end{array}$




\section{Lista de Figuras}

1.1 Inferência de Rede Gênica por meio de engenharia reversa. O sistema biológico é complexo, composto por diferentes elementos que formam uma rede de interações, que por sua vez regula a expressão gênica. De todo este complexo sistema, apenas os dados de expressão adquiridos são utilizados. Estes dados são quantificados, préprocessados e então utilizados pelo algoritmo de inferência de redes, que tem por objetivo recuperar a rede que teria gerado os dados de expressão observados. A rede inferida é comumente comparada a uma parte da rede gênica conhecida (gold standard) para avaliação do algoritmo. . . . . . . . . . . . . . . . . 2

1.2 Visão geral do trabalho. Diferentes tipos de dados multiniveis são pré-processados e preparados para o uso. Estes dados, a teoria de redes complexas e métodos de inferência de redes gênicas são utilizados no desenvolvimento de modelos de inferência de redes gênicas que fazem integração de dados. . . . . . . . . . . . . . . . . . . . 4

2.1 Adaptado de: [Vicente, 2006]. Microarray. (I) Amostras em diferentes condições (controle e experimental). (II) e (III) Isola-se os genes expressos. (IV) Identificação de cada amostra com marcadores bioquímicos. (V) Junção das amostras em um único volume. (VI) Hibridização do volume no microarray (as moléculas de ambas amostras se ligarão aos spots de seus respectivos genes, na quantidade proporcional a sua expressão). (VII) O chip de microarray é varrido por um laser e a quantidade de luz em cada spot é quantificada. Assume-se que a intensidade da luz será proporcional à quantidade de gene expresso em cada uma das amostras. . . . . . . . . . . . . . . .

2.2 Cenário hipotético de uma rede biológica e sua respectiva representação como uma rede de genes. (1) as proteínas Fatores de Transcrição são nomeadas como TF-A, TF-B e TF-C respectivamente. Os genes (DNA e o transcrito) são nomeados como Gene A, Gene B e Gene C. (2) A representação do sistema como uma rede e (3) o grafo codificado numa matriz de adjacências. Na matriz, quando existe uma aresta entre um par de vértices a célula correspondente recebe o valor 1, caso contrário recebe o valor 0. Por exemplo, a primeira linha codifica as arestas de A para B e de

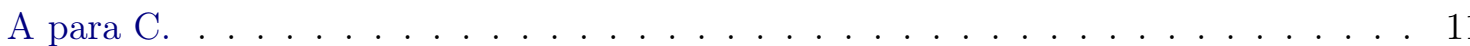

2.3 Bacias de atração. Todas as transições possíveis da Rede Booleana. Duas bacias de atração sendo a maior com 7 estados e a menor com um único estado. . . . . . . . . . 13 
2.4 Transições de Estados entre o estado $\{1,1,1\}$ e os demais em uma Rede Booleana Probabilística. As linhas contínuas ilustram as transições de maior probabilidade, e as linhas pontilhadas as transições de menor probabilidade tendo o estado $\{1,1,1\}$ como origem. Há transição entre todos os estados do sistema, mas a figura destaca apenas as transições adicionadas ao estado $\{1,1,1\} \ldots \ldots \ldots \ldots \ldots$

2.5 Adaptado de [Duda et al., 2000]. Etapas do design de um sistema de reconhecimento de padrões. . . . . . . . . . . . . . . . . . . . . . . 1

2.6 Caracterização e Representação. Adaptado de [Costa et al., 2007a]. As redes A e B são representadas como grafos. Várias características (medidas) são extraídas de ambas as redes, por exemplo grau médio dos vértices, diâmetro, etc. O conjunto das $n$ características compõe um vetor de características para cada rede. A partir da caracterização é possível comparar as redes complexas no espaço de características.

4.1 Similaridade, Precisão e Sensibilidade obtida com a variação do peso entre a informação biológica e o dado de expressão. Quando o peso é igual a 0 apenas o dado de expressão é considerado. Quando o peso é igual a 1 apenas o dado de PPI é considerado. O aumento do peso para o dado biológico de PPI produz aumento da similaridade e o resultado também mostra que o ganho não é linear e para Sensibilidade é melhor que um ganho linear.

4.2 Rosetta Stone e KEGG. Variação da Similaridade, PPV e Sensibilidade pela variação do peso do dado biológico. A contribuição do dado não é linear e o ganho em Sensibilidade é maior que o ganho em precisão. . . . . . . . . . . . . . . . .

4.3 Rosetta Stone, KEGG e GO. Variação da Similaridade, PPV e Sensibilidade pela variação do peso do dado biológico. A contribuição do dado biológico não é linear e o ganho em Sensibilidade é maior que o ganho em precisão. . . . . . . . . . . . . . . . 4

4.4 Avaliação com a rede formada pelos genes hub e inferência com dados de interação de proteína (Rosetta Stone). Variação da Similaridade, PPV e Sensibilidade pela variação do peso do dado biológico. A contribuição do dado biológico não é linear e o ganho em Sensibilidade é maior que o ganho em precisão.

4.5 Avaliação com a rede formada pelos genes hub e inferência com dados do KEGG. Variação da Similaridade, PPV e Sensibilidade pela variação do peso do dado biológico. A contribuição do dado biológico não é linear e o ganho em Sensibilidade é maior que o ganho em precisão.

4.6 Precisão (PPV) do algoritmo SFFS-SW de acordo com a variação do peso da informação topológica. $\mathrm{O}$ algoritmo atinge o melhor resultado para peso $w=0.8$ para qualquer valor de $k$. A precisão decresce rapidamente quando o algoritmo reduz o peso do dado de expressão, chegando próximo de zero quando o ignora $(w=1.0)$. Este comportamento mostra que tanto expressão quanto a informação topológica são necessários para aumentar a acurácia do método. 
4.7 Trajetória do coeficiente de clustering para diferentes valores de $k=1,2,3,4$. A linha $w=0$ mostra a inferência na fase 1 do algoritmo SFFS-SW (apenas com dado de expressão). O ponto em destaque indica o início da fase 2 quando a informação topológica é usada. Nota-se que há um aumento gradual do coeficiente de clustering, independente do peso, indicando que a cada nó revisitado, o conjunto de preditores escolhido é mais coerente com a topologia global do que na fase 1 . . . . . . . . . . . 51

4.8 Trajetória do caminho mínimo médio para diferentes valores de $k=1,2,3,4$. A linha $w=0$ mostra a inferência na fase 1 do algoritmo SFFS-SW (apenas com dado de expressão). O ponto em destaque indica o início da fase 2 quando a informação topológica é usada. . . . . . . . . . . . . . . . . . . 52

4.9 Similaridade entre a rede inferida e a rede regulatória de Arabidopsis com respeito à variação do peso do dado biológico. O dado de localização (que informa localização física) apresentou melhor resultado que os demais dados (informação funcional e da vida metabólica). . . . . . . . . . . . . . . . . . . . . . . 53

4.10 Avaliação da similaridade com a variação do peso do dado biológico de localização, para diferentes thresholds da função critério. . . . . . . . . . . . . . . . . 54

5.1 Exemplo de uma estrutura de Ontologia de Genes (Gene Ontology - GO) . . . . . . 57 


\section{Lista de Tabelas}

3.1 Resumo das fontes de dados utilizadas para avaliação da inferência . . . . . . . . . . 35

3.2 Interseção dos conjuntos de dados . . . . . . . . . . . . . . . . . 35

3.3 Matriz de Confusão. TP $=$ verdadeiro positivo (True Positive), FN = falso negativo (False Negative), $\mathrm{FP}=$ falso positivo (False Positive), $\mathrm{TN}=$ verdadeiro negativo(True Negative). . . . . . . . . . . . . . . . . . . 35

4.1 Precisão (PPV), Sensibilidade (Recall) e Similaridade para $k=1,2,3,4$ e pesos $=$

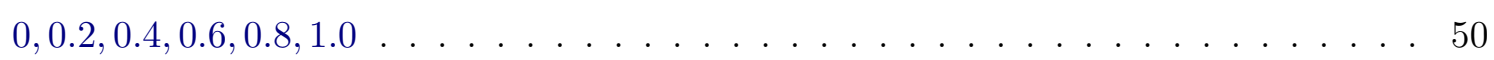

4.2 O conjunto de dados de valiação possui 5.974 genes. . . . . . . . . . . . . . 52 


\section{Capítulo 1}

\section{Introdução}

\subsection{Motivação}

A Inferência de Redes Gênicas (GNs, do inglês Gene Networks) através do Processamento de Sinais Genômicos (GSP, do inglês Genomic Signal Processing) é uma área de pesquisa em Bioinformática que tem se destacado no estudo da Biologia de Sistemas [Bansal et al., 2007, Marshall et al., 2007, Shmulevich e Dougherty, 2007].

A complexa regulação dos processos biológicos é possível por meio das redes de interações entre diversos componentes celulares como DNA, mRNA, enzimas, proteínas kinases, ativadores, inibidores, receptores, etc. Além disto, proteínas podem atuar como parte de grandes agregados como por exemplo em complexos de Fatores de Transcrição (TFs, do inglês Transcription Factors), que atuam no controle da transcrição de genes alvos [De Bodt et al., 2009]. Também, proteínas e peptídeos podem interagir em vias de sinalização. Desvendar a forma como milhares de componentes celulares interagem e de que modo estas interações afetam a dinâmica da célula, é um dos grandes desafios atuais de pesquisa em bioinformática. A caracterização de GNs pode ser útil, por exemplo, para o projeto de drogas que considere não apenas o gene alvo, mas também sua rede de interações. Como outro exemplo, pode ser aplicada na identificação de um conjunto de genes que atue em uma via metabólica de interesse.

Neste sentido, uma vez que os componentes celulares não atuam isoladamente, mas como um conjunto de interações [Barabási et al., 2011], passa a ser essencial compreender e caracterizar essa rede de interações para uma melhor compreensão das funções de cada componente, da dinâmica celular e, consequentemente, de seu efeito no organismo [Lu et al., 2005].

Com relação à expressão gênica, a interação entre TF (Fator de Transcrição, do inglês Transcription Factor) e DNA é responsável pela alteração dos níveis de expressão gênica. A rede de interações entre TFs, DNA e outros componentes não pode ser observada diretamente, no entanto, é possível observar e quantificar a expressão de milhares de genes simultaneamente. Neste sentido, a inferência de GNs consiste em, a partir dos dados de expressão, recuperar a rede de interações que teria produzido os respectivos dados de entrada. Este processo também é conhecido na literatura como engenharia reversa [Baralla et al., 2009].

A inferência de GNs é realizada a partir de duas categorias de dados de expressão: (a) séries temporais, nas quais se pode observar a relação entre a expressão dos genes ao longo do tempo e (b) dados estacionários, nos quais observa-se a expressão gênica em diferentes condições experimentais sem levar em conta o tempo. 
A Figura 1.1 apresenta este processo. Nele, de todo o complexo sistema celular, somente a expressão observada é utilizada. Este dado - que pode ser adquirido de diferentes formas, como será descrito adiante - é pré-processado, em seguida um algoritmo de inferência de redes gênicas é aplicado e uma rede de interações é inferida a partir do dado de expressão. Comumente existe uma pequena parte da rede gênica do organismo já conhecida (rede gold standard), validada experimentalmente em laboratório por meio de diferentes técnicas. Para avaliação do método de inferência, a rede predita é comparada com a rede gold standard utilizando algum critério quantitativo.

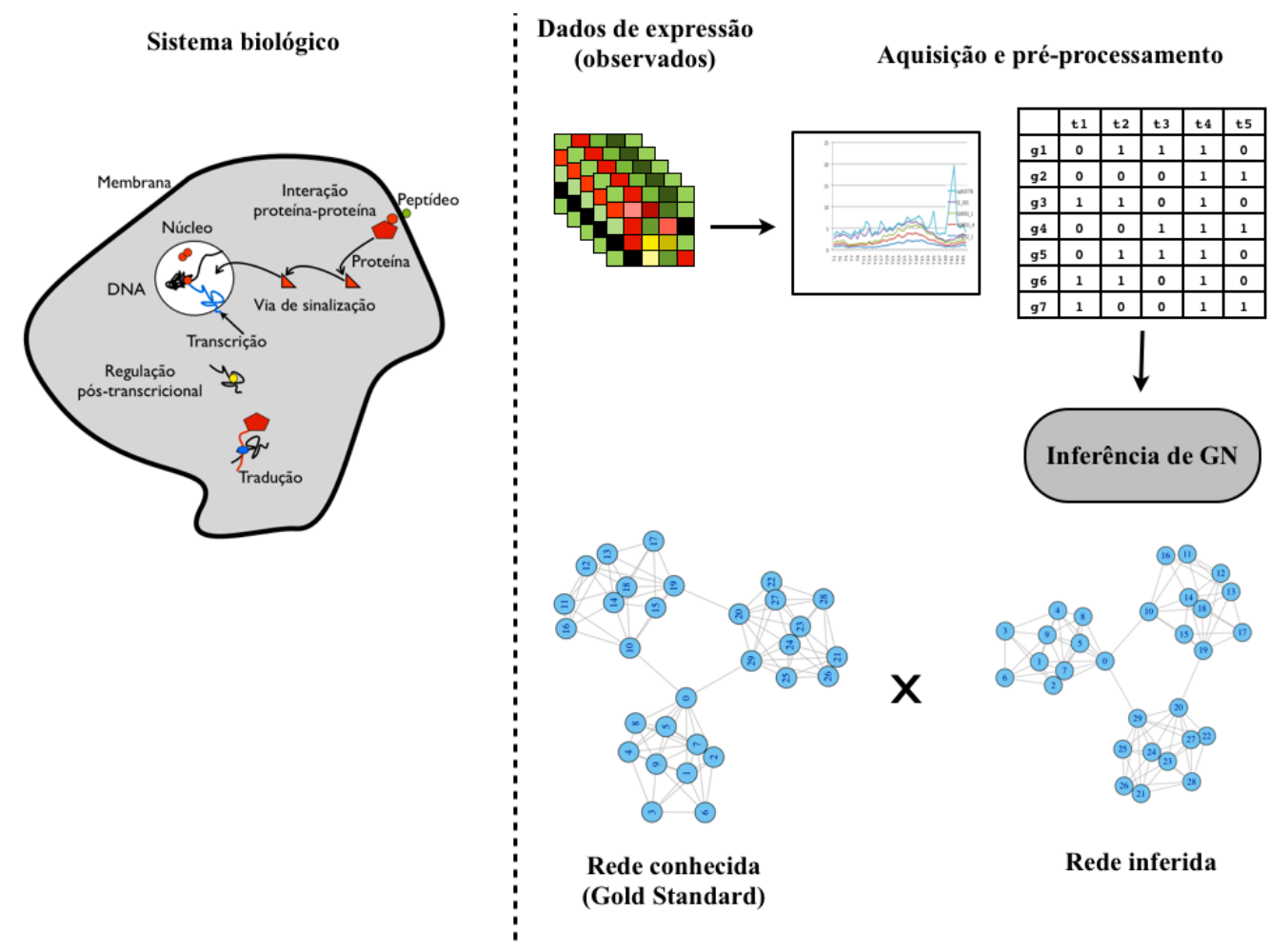

Figura 1.1: Inferência de Rede Gênica por meio de engenharia reversa. O sistema biológico é complexo, composto por diferentes elementos que formam uma rede de interações, que por sua vez regula a expressão gênica. De todo este complexo sistema, apenas os dados de expressão adquiridos são utilizados. Estes dados são quantificados, pré-processados e então utilizados pelo algoritmo de inferência de redes, que tem por objetivo recuperar a rede que teria gerado os dados de expressão observados. A rede inferida é comumente comparada a uma parte da rede gênica conhecida (gold standard) para avaliação do algoritmo.

Apesar do grande volume de dados de expressão disponível (quantidade de genes observados simultaneamente), ainda há uma forte limitação e desafio na inferência de GNs devido ao problema conhecido como maldição da dimensionalidade [Jain et al., 2000]: o número de variáveis (centenas ou milhares de genes) é muito maior que o número de amostras de expressão (geralmente dezenas). A princípio poderia se imaginar que sem limitação financeira, seria possível obter um número muito maior de amostras e, com isso, a maldição da dimensionalidade deixaria de ser relevante a esse problema. No entanto, na maioria dos casos a limitação deve-se a fatores operacionais e técnicos. Por exemplo, para se obter amostras de DNA de uma planta, é necessário obter uma parte de um tecido (caule, folha, etc.). Ao retirar uma folha, por exemplo, altera-se a condição experimental, uma vez que a folha é parte essencial na fotossíntese. Em outras palavras, ao obter uma amostra, pode-se provocar um stress, alterando aquela amostra (planta) em questão, tornando-a inviável para uma próxima amostragem. Assim, para várias amostras, seriam necessários várias unidades da planta (preferencialmente clones) sob as mesmas condições experimentais de iluminação, temperatura, 
etc. Como outro exemplo, pode-se citar uma amostra de tecidos cancerígenos de tumor cerebral humano. A obtenção de várias amostras temporais ou em diferentes condições experimentais neste caso é ainda mais difícil. Há portanto, alguns fatores significativos que levam a uma limitação no número de amostras que podem ser obtidas.

Como uma forma de contornar este problema, algumas soluções que fazem integração de outros dados além do dado de expressão têm sido propostas no estudo de redes biológicas [Hecker et al., 2009, Lopes et al., 2014a,b, Ray et al., 2009, Vicente et al., 2011], especialmente na combinação de dados para determinação da função de genes. No entanto, o efeito da integração na inferência é pouco explorado. De forma geral, os modelos fazem uma integração ad hoc, isto é, um modelo de integração é geralmente proposto para um organismo em particular ou ainda para uma determinada fonte de dados biológicos. Ainda são incipientes os estudos na literatura que explorem a integração de dados de forma sistemática e que seja amplamente generalizado para aplicação em diferentes organismos e condições. Neste sentido é necessário compreender a relação entre os diferentes tipos de dado e a respectiva contribuição na identificação dos relacionamentos entre os genes, isto é, entre os demais dados biológicos e a rede inferida apenas a partir do dado de expressão gênica. Também, é importante compreender a contribuição de cada tipo de dado, em termos de de precisão e redução do erro de estimação. Além dos dados referentes aos componentes celulares, outro aspecto importante a ser considerado é a topologia das redes gênicas.

Além disto, um sistema biológico pode ser abordado em múltiplos níveis: há uma rede de regulação transcricional (na qual TFs interagem com o DNA), os genes transcritos e traduzidos em proteínas podem interagir em um nível superior em uma rede de interação de proteínas, vias metabólicas e vias de sinalização celular. Há também organelas, como os ribossomos, parede celular, fatores epigenéticos como metilação, para citar apenas alguns. Logo, descobrir como a interação entre componentes celulares acontece em vários níveis e como as relações entre eles relaciona-se ao fenótipo produzido é um grande desafio. Neste sentido, buscar compreender a relação entre as diferentes tipos de dados biológicos disponíveis e como integrá-los na inferência de redes pode contribuir para o avanço da pesquisa nesta área.

\subsection{Objetivos}

O objetivo deste trabalho é investigar métodos para integração de diferentes dados biológicos na inferência de GNs além dos dados de expressão gênica. Um aspecto importante a ser considerado é a heterogeneidade destes outros tipos de dados. Existem dados que estão disponíveis de forma quantitativa, em escalas intervalares e proporcionais, há dados de tipo qualitativo, nominal ou ordinal. Por exemplo, enquanto a expressão dos genes fornece um dado de tipo quantitativo (que dependendo do modelo adotado ainda podem ser classificadas em valores contínuos ou discretos), o dado da interação entre as proteínas correspondentes a um par de genes pode ser binário (significando que as proteínas correspondentes interagem ou não interagem). Ainda, a anotação da localização celular é de tipo qualitativa e nominal, já que não há ordem entre uma localização ou outra. Além disto, por exemplo, o dado do processo biológico ou da função de um gene pode ser de tipo hierárquico como acontece no Grafo Acíclico Dirigido (DAG, do inglês Directed Acyclic Graph) da anotação do GO (Gene Ontology) [Harris et al., 2004]. Assim, um dos direcionamentos naturais da investigação é procurar compreender a contribuição de diferentes tipos de dados na inferência. 
Outro aspecto importante abordado neste trabalho, ainda relacionado à questão da heterogeneidade dos dados, é se os diferentes tipos de dados podem ser agrupados ou categorizados segundo o seu efeito na inferência.

Um terceiro aspecto abordado neste trabalho trata de como considerar a topologia das redes inferidas. Sabe-se a partir da literatura, que várias redes de diferentes fenômenos naturais apresentam certos padrões topológicos [Albert, 2005, Barabási, 2009, Carroll et al., 2004, Stuart et al., 2003]. Além disto, a teoria de redes complexas estuda, dentre outras coisas, como caracterizar redes [Costa et al., 2008, Watts e Strogatz, 1998]. Assim, um dos objetivos consiste em investigar como integrar a informação topológica de modo a inferir uma rede o mais próxima possível de uma topologia esperada.

Ainda, um outro aspecto investigado neste trabalho trata da combinação de diferentes tipos de dados na inferência de GNs. É importante avaliar se a inclusão de múltiplos dados é melhor do que uma integração individual, isto é, inferir GNs a partir dos dados de expressão e múltiplos dados em conjunto ou integrar um único tipo de dado por vez?

A Figura 1.2 apresenta uma visão geral deste trabalho. Em resumo, os diferentes tipos de dados disponíveis referem-se a múltiplos níveis do sistema biológico que vão desde o genótipo até o fenótipo. Em outras palavras, desde a matéria mais elementar que constitui a célula, como a molécula de DNA, até a forma macroscópica tal como o formato de uma folha, por exemplo, adquirida por meio de bio-imagens. Neste trabalho são usados dados de sequência de DNA, expressão gênica, interação proteína-proteína, anotação de via metabólica e ontologia de genes. Estes dados, em conjunto com métodos de inferência de redes já conhecidos e com a teoria de redes complexas, são utilizados para desenvolver as metodologias de integração de dados na inferência de GNs.

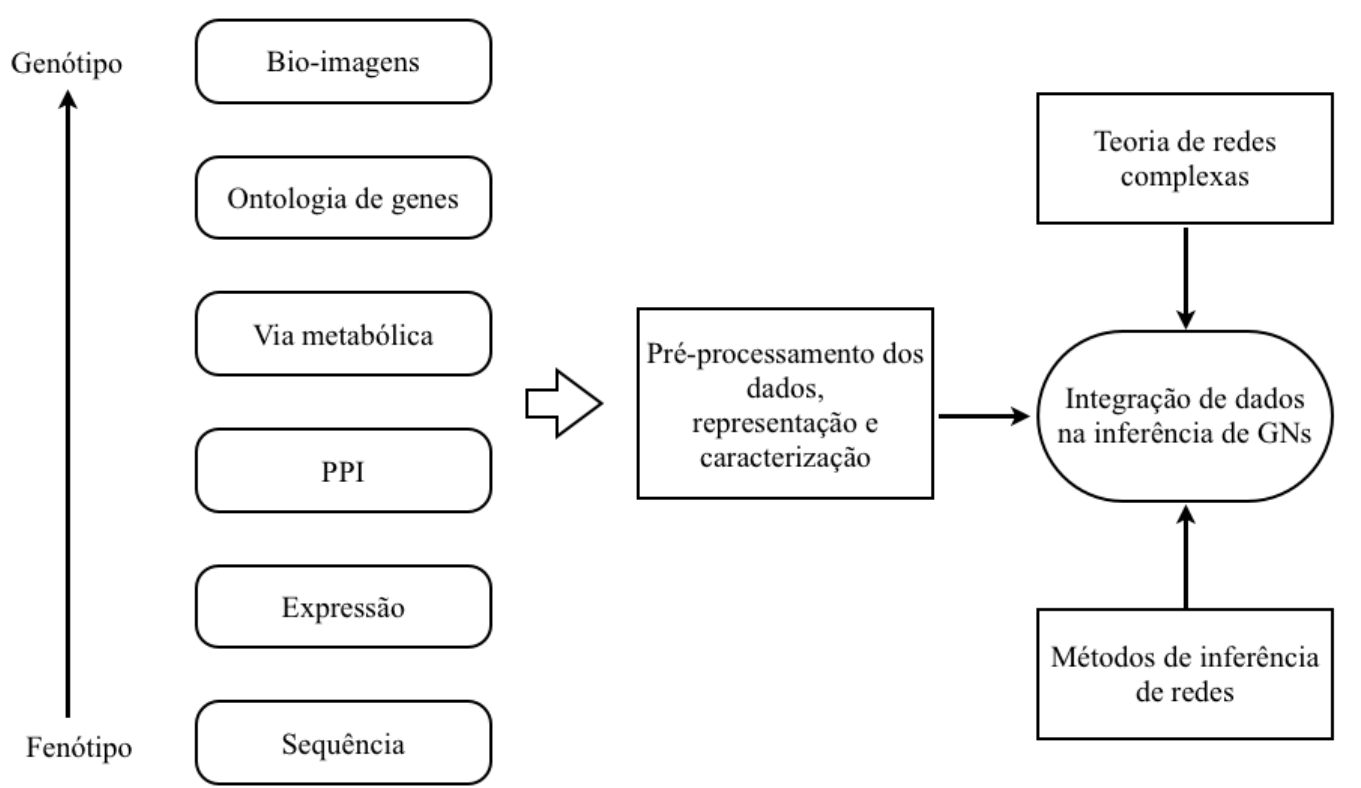

Figura 1.2: Visão geral do trabalho. Diferentes tipos de dados multiníveis são pré-processados e preparados para o uso. Estes dados, a teoria de redes complexas e métodos de inferência de redes gênicas são utilizados no desenvolvimento de modelos de inferência de redes gênicas que fazem integração de dados.

Finalmente, este trabalho tem por objetivo desenvolver um conjunto de dados de expressão e de rede de relacionamentos conhecidos para a inferência e a validação de modelos de integração de dados, baseado em dados reais. Um dos problemas de estudar a integração de dados é a ausência de 
conjuntos de dados pré-processados e preparados para este fim. Neste trabalho foi construído um conjunto de dados para inferência e validação baseado no organismo Arabidopsis thaliana.

\subsection{Contribuições}

As principais contribuições deste trabalho estão relacionadas à integração de dados para inferência de GNs, bem como uma revisão dos diferentes tipos de informações biológicas que podem ser aplicadas. Mais especificamente, as contribuições desse trabalho são:

- Formalização e implementação de um algoritmo de inferência de redes gênicas para a integração de informações formatadas como grafos (matrizes de adjacências ou listas de arestas), como por exemplo, rede de interação proteína-proteína. O desenvolvimento deste trabalho [Vicente et al., 2011] contou com a colaboração do Prof. Dr. Ronaldo Fumio Hashimoto. A proposta é que o algoritmo proposto, em conjunto com os demais algoritmos implementados neste trabalho, seja integrado ao software DimReduction [Lopes et al., 2008a,c].

- Avaliação da contribuição de quatro diferentes tipos de informações biológicas na inferência de GNs: (a) interação proteína-proteína, (b) Rosetta Stone Fusion Proteins (uma predição da interação entre proteínas baseadas na sequência de DNA), (c) anotação de vias metabólicas do KEGG, (d) anotação do Gene Ontology. Neste trabalho [Vicente et al., 2012], que é uma extensão do item anterior, as informações são fornecidas no formato de grafos. Por exemplo, quando dois genes estão anotados na mesma via no KEGG, segundo algum critério, uma aresta é adicionada a eles. Além disso, o conjunto de dados de inferência e validação foi construído a partir da combinação de conjuntos de dados pré-existentes e publicados, disponíveis no formato de grafos e de dados de expressão pré-processados, também previamente publicados. Avaliou-se também o uso combinado de dados distintos. Para isto foram construídos quatro conjuntos de dados para inferência e validação. Nesta contribuição foram utilizados dados do organismo Plasmodium falciparum.

- Formalização e implementação de um algoritmo de inferência de redes que integra informação topológica. Neste trabalho [Vicente e Lopes, 2014] assumiu-se que a topologia da rede gênica é Small World e de acordo com o modelo gerador de Watts e Strogatz [Barrat e Weigt, 1999, Strogatz, 2001, Watts e Strogatz, 1998]. Foi desenvolvido uma nova função critério (MCESW) para a inferência de GNs, a qual foi baseada na Entropia Condicional Média (MCE, do inglês Mean Conditional Entropy) [Lopes et al., 2008c, 2010, 2011] e em duas características topológicas das redes Small World: alto coeficiente de clustering e baixo caminho mínimo médio.

- Criação de conjuntos de dados para inferência e validação de modelos de integração de dados. Foi construído um conjunto de dados composto de 1.206 amostras de dados de expressão de 5.974 genes de Arabidopsis thaliana [Vicente et al., 2015]. Além dos dados de expressão, o conjunto é composto por uma rede gold standard com 8.509 arestas e 3 tipos de informações biológicas pré-processadas, de tipo qualitativa (função, localização celular, via metabólica). Ainda neste contexto, avaliou-se a integração de diferentes informações biológicas e como elas contribuem na identificação dos relacionamentos entre os genes, i.e., na inferência de GNs. 


\subsection{Organização do trabalho}

Este trabalho está organizado da forma descrita a seguir. No Capítulo 2 (Revisão) é apresentada uma revisão bibliográfica, abordando o conceito de biologia sistêmica, a obtenção de dado de expressão gênica, a representação das redes de genes como grafos, o modelo de Redes Booleanas, o modelo de Redes Booleanas Probabilísticas e o de Redes Gênicas Probabilísticas, os fundamentos relacionados a inferência baseada em Entropia Condicional Média, o conceito de Escore Biológico e os tipos de informações biológicas. No Capítulo 3 (Materiais e Métodos) são apresentados os dados utilizados no trabalho, métodos e algoritmos implementados bem como a metodologia para avaliação dos resultados. No Capítulo 4 (Resultados) são apresentados os resultados obtidos com a aplicação dos métodos desenvolvidos nos respectivos conjuntos de dados para inferência e validação, bem como uma discussão dos resultados. Finalmente, no Capítulo 5 (Conclusão e trabalhos futuros) é apresentada uma discussão geral sobre o trabalho bem como as perspectivas de trabalhos futuros. 


\section{Capítulo 2}

\section{Revisão Bibliográfica}

Neste capítulo são apresentados alguns conceitos e publicações relacionadas, importantes para a compreensão deste trabalho. Inicialmente serão apresentados os conceitos e definições no que diz respeito à biologia sistêmica.

A seção seguinte trata dos tipos de dados utilizados neste trabalho: dados de expressão, redes de interação proteína-proteína, vias metabólicas, ontologia de genes e dados de sequência.

As Seções 2.3 e 2.4 apresentam a questão da representação de redes como grafos e a modelagem de redes gênicas, respectivamente. Na Seção 2.5 são apresentados os conceitos de seleção de características, busca e definição de função critério, utilizados nos métodos de inferência de GNs, apresentados na Seção 2.6. Na Seção 2.7 é apresentada a teoria de redes complexas, os conceitos de representação e caracterização de redes.

Finalmente, na Seção 2.8 é apresentada a questão da integração de dados.

\subsection{Biologia Sistêmica}

Segundo [De Bodt et al., 2009], a regulação de diversos processos biológicos só é possível devido à interação entre os componentes celulares, uma vez que os elementos (proteínas, DNA, RNA, etc.) não atuam isoladamente mas no contexto de uma rede de interações [Barabási et al., 2011]. Logo, estudar a relação entre as moléculas biológicas é um passo importante para compreender a função das proteínas e de outros elementos, bem como o comportamento celular [Lu et al., 2005] e apontar como os relacionamentos entre os componentes celulares produzem os fenótipos. Portanto, compreender o sistema biológico no qual milhares de componentes celulares de diferentes tipos interagem de modo a manter a homeostase, é um dos maiores desafios atuais de pesquisa em bioinformática. O estudo das interações entre moléculas biológicas, não de forma isolada, mas no contexto holístico por meio de uma rede de interações é conhecido na literatura como Biológica Sistêmica (do inglês, Systems Biology).

\subsection{Dados biológicos}

\subsubsection{Dados de expressão gênica}

Segundo o Dogma Central da Biologia Molecular, o DNA é transcrito em RNA e o RNA é traduzido em proteína[Voet et al., 2005]. Quando uma seção do DNA (um gene) é transcrito diz-se 
que houve expressão daquele gene. Atualmente, sabe-se também da importância dos RNAs não codificantes que atuam de forma ativa nos processos regulatórios e pós-transcricionais.

Embora cada célula em um dado ser vivo contenha a mesma cópia de DNA, as células expressam genes diferentes em condições e momentos distintos. Em outras palavras, os genes não são todos transcritos e traduzidos ao mesmo tempo, mas existem mecanismos de regulação que determinam quando cada gene será transcrito e em que quantidade. Por exemplo, certas proteínas chamadas fatores de transcrição podem ativar ou inibir a transcrição de um gene [Lodish et al., 2000].

Nas últimas décadas, a crescente melhoria nas tecnologias genômicas de alto desempenho permitiram medir a expressão de milhares de genes simultaneamente. Atualmente, conta-se com dados produzidos por diferentes tecnologias como a Serial Analysis of Gene Expression (SAGE) [Velculescu et al., 1995], Microarrays [Schena et al., 1995] e mais recentemente RNA-Seq [Wang et al., 2009]. Graças a redução de custo para a produção deste tipo de observação e consequentemente da grande quantidade de dados disponíveis, a inferência de redes de genes a partir de dados de expressão passou a ser uma abordagem utilizada no estudo das interações gênicas [D'haeseleer et al., 2000].

Para explicar como os dados de expressão podem ser obtidos, será apresentado como é realizada a obtenção de dados com DNA-Microarray. O detalhamento da técnica de microarray de DNA será explicado a seguir com o suporte da Figura 2.1.

A técnica baseia-se na propriedade do DNA de que cada lado da fita de DNA liga-se à sua fita complementar. Este processo é chamado de hibridização. Em um experimento deste tipo [Strachan et al., 1999], primeiro as amostras são obtidas em condições distintas. Por exemplo, a amostra controle no instante de tempo $t=0$ e a experimental no instante $t=1$.

No passo seguinte, isola-se o mRNA das amostras (representado nas etapas II e III da figura). Então utiliza-se fluoróforos (e.g. cy3 e cy5) para marcar cada conjunto (IV).

Após marcados, os dois conjuntos são então unidos $(\mathrm{V})$, para depois serem hibridizados no microarray (VI). Os microarrays são lâminas que possuem vários spots (pequenas cavidades na lâmina), nos quais milhares de genes são afixados (cada gene em um spot). Cada spot é construído com DNA que pode ligar-se somente a fita complementar de cDNA daquele gene. Assim, quando o conteúdo da mistura de cDNAs marcados é hibridizado no microarray, os trechos de cDNA se ligarão, cada um, à sua fita complementar de DNA. Desta forma um gene que se expressou muito terá mais fitas de cDNA hibridizadas que um gene que se expressou pouco. Um laser percorre o microarray fazendo refletir a luz verde numa leitura e a luz vermelha em outra. A intensidade luminosa deve ser proporcional à quantidade de fitas de cDNA marcada com cada um dos fluoróforos, portanto, proporcional à expressão do gene.

A fase final consiste em digitalizar, tratar e processar as imagens dos microarrays e quantificálas, geralmente em intervalos reais entre -1 e +1 . Os dados contínuos podem ser posteriormente discretizados para adequá-los a modelos particulares, como é o caso das Redes Booleanas, por exemplo.

\subsubsection{PPI - Interação proteína-proteína}

O mapeamento de larga escala da interação entre proteínas foi inicialmente realizado em organismos modelo como Saccharomyces cerevisiae [Fromont-Racine et al., 1997], Caenorhabditis elegans [Walhout et al., 2000] e Drosophila melanogaster [Giot et al., 2003]. A interação entre proteínas é 


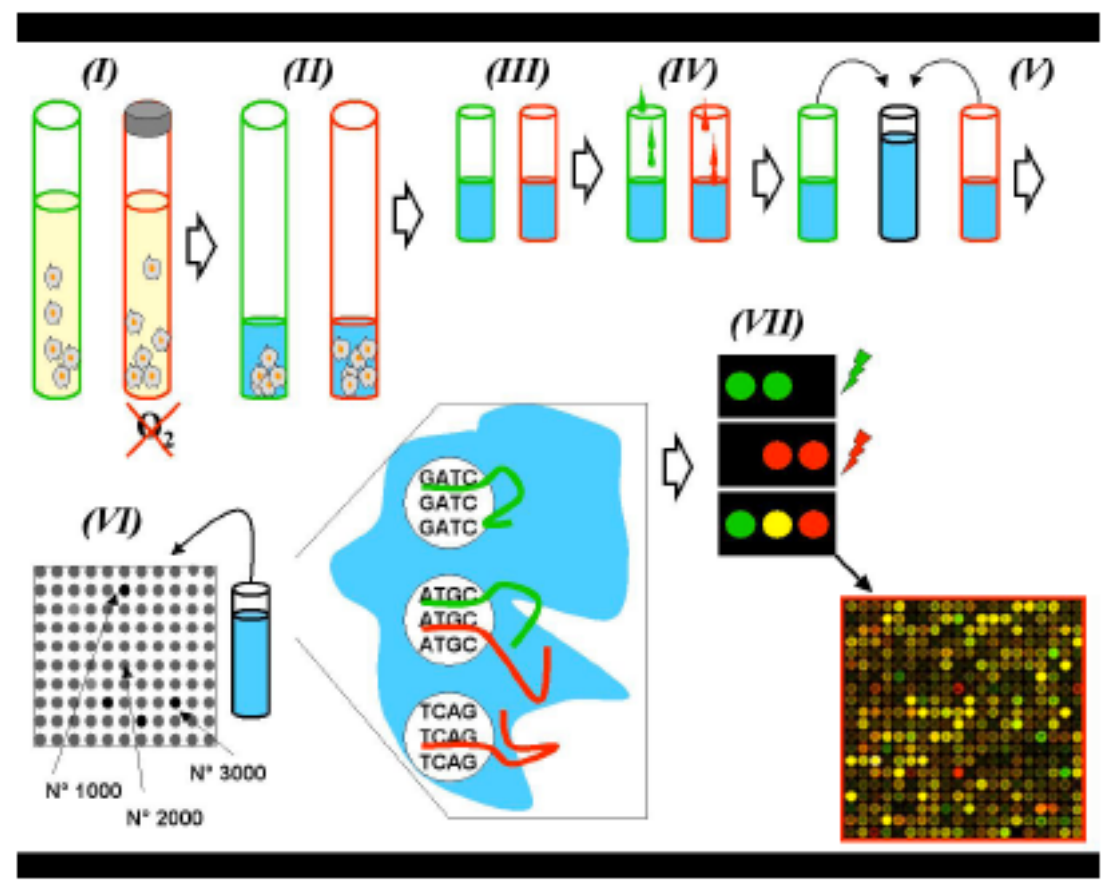

Figura 2.1: Adaptado de: [Vicente, 2006]. Microarray. (I) Amostras em diferentes condições (controle e experimental). (II) e (III) Isola-se os genes expressos. (IV) Identificação de cada amostra com marcadores bioquímicos. (V) Junção das amostras em um único volume. (VI) Hibridização do volume no microarray (as moléculas de ambas amostras se ligarão aos spots de seus respectivos genes, na quantidade proporcional a sua expressão). (VII) O chip de microarray é varrido por um laser e a quantidade de luz em cada spot é quantificada. Assume-se que a intensidade da luz será proporcional à quantidade de gene expresso em cada uma das amostras.

verificada por meio de uma técnica de biologia molecular chamada sistema de duplo-híbrido em levedura (Y2H, do inglês Yeast two-hybrid) na qual a levedura é utilizada como organismo suporte da técnica [Rual et al., 2005]. Assim, a interação física entre milhares de proteínas pode ser verificada de modo a se construir uma rede de interação proteína-proteína(PPI, do inglês Protein-Protein Interaction). Este tipo de dado é importante porque corresponde a um nível pós-transcricional de interação entre os componentes celulares e fornece a informação sobre o aspecto da interação entre proteínas já traduzidas. A relação entre níveis de expressão de mRNA e redes de proteína foi investigada e revelou que há uma relação entre subunidades de complexos de proteínas e a co-expressão dos genes correspondentes ao longo do tempo [Jansen, 2002]. Assim, este tipo de dado multinível (veja Figura 1.2) é importante para a inferência de redes porque pode contribuir na redução do erro de estimação, uma vez que mantém alguma relação com os dados de expressão.

\subsubsection{KEGG}

O KEGG (Kyoto Encyclopedia of Genes and Genomes) [Kanehisa, 2000] é um banco de dados para análise sistemática da função gênica que fornece informação sobre a via metabólica na qual o gene está envolvido. Deste modo, a partir dos dados do banco é possível relacionar genes a partir de sua participação comum em vias metabólicas. 


\subsubsection{Gene Ontology}

O Gene Ontology [Ashburner et al., 2000] é um projeto para desenvolver uma representação computacional do conhecimento biológico sobre os genes e seus produtos. O dado é estruturado de forma hierárquica como um DAG e define um vocabulário controlado, de modo a fornecer uma padronização de termos para anotar informações sobre os genes e seus produtos. O GO fornece dado sobre três aspectos: o processo celular no qual o gene está envolvido, o componente celular e a função molecular. Este tipo de dado é útil por exemplo para verificar se um conjunto de genes possui algum aspecto biológico em comum.

\subsubsection{Rosetta Stone Fusion Proteins}

A detecção de interação entre proteínas a partir de sequências genômicas foi inicialmente proposta por [Marcotte, 1999]. A idéia do método é que algumas proteínas que interagem em um organismo formam uma única proteína em outro organismo. Em um organismo há duas sequências gênicas distintas e no outro há uma única sequência. No trabalho de [Marcotte, 1999], para encontrar possíveis pares de proteínas de Escherichia coli que interagem, foram selecionadas sequências de proteínas com este padrão de homologia. Os pares de sequências não homólogas que compõem o par em um organismo mas que são uma única sequência em outro genoma foram nomeadas de "Rosetta Stone" (em analogia à Pedra de Rosetta que contém textos em três línguas distintas e que foi chave para decifrar os hieróglifos egípcios) porque "decifra" a interação entre proteínas a partir de um conjunto de sequências. Assim, este tipo de abordagem fornece um dado de interação proteína-proteína obtido indiretamente a partir de sequências genômicas. Este tipo de dado é importante pois nem sempre uma rede PPI obtida por Y2H está disponível, além de fornecer um dado adicional sobre a interação de proteínas.

\subsection{Representação das Redes Gênicas}

Uma GN é um modelo que representa as relações entre os genes, uma simplificação da complexidade do mundo biológico real.

Uma rede de genes pode ser modelada como um grafo no qual os vértices representam os genes ou proteínas e as arestas representam as relações entre eles. As representações podem variar em cada modelo. As arestas, por exemplo, podem ser não direcionadas indicando apenas que aqueles genes possuem uma relação sem sugerir algum tipo de causalidade. Podem também ser direcionadas (indicando uma relação causal), possuir valores (representando a intensidade da relação) ou possuir um sinal (positivo ou negativo, indicando por exemplo ativação ou inibição).

A Figura 2.2 apresenta um cenário hipotético que exemplifica a dinâmica de um sistema biológico. Neste cenário o gene-TF-A (uma sequência de DNA) está inicialmente inativo, isto é, não está sendo transcrito em RNA mensageiro (mRNA). Não havendo mRNA não haverá tradução deste e, como consequência, a proteína $T F-A$ não será produzida.

Quando uma proteína $\mathrm{TF}-\mathrm{C}$ liga-se à região a montante (upstream) do gene-TF-A este é transcrito e a proteína TF-A é sintetizada. Diz-se que $C$ ativou $A$. Uma vez que existe a proteína $\mathrm{TF}-\mathrm{A}$, esta liga-se à região a montante do gene-TF-B, este é transcrito e traduzido na proteína $\mathrm{TF}-\mathrm{B}$. 


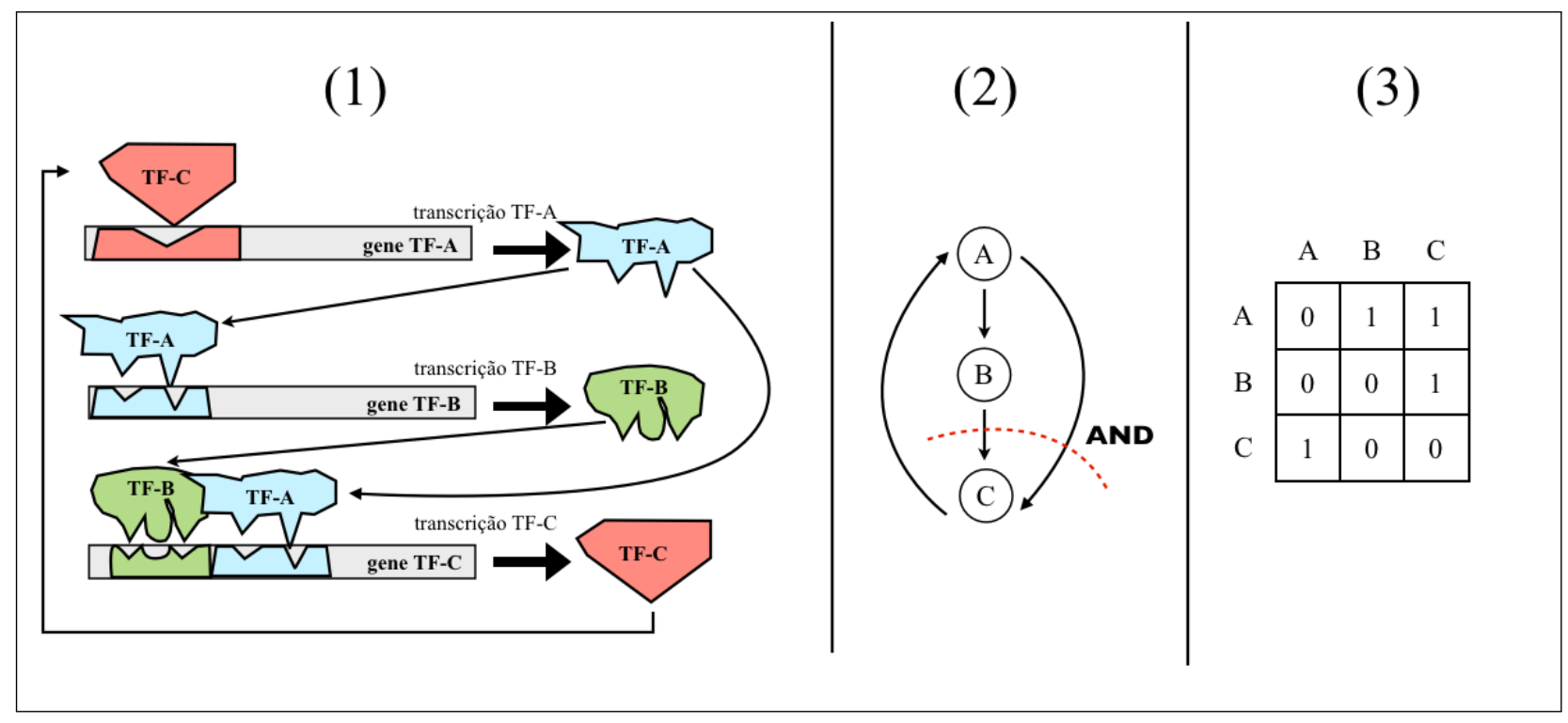

Figura 2.2: Cenário hipotético de uma rede biológica e sua respectiva representação como uma rede de genes. (1) as proteínas Fatores de Transcrição são nomeadas como TF- $A$, TF-B e TF-C respectivamente. Os genes (DNA e o transcrito) são nomeados como Gene A, Gene B e Gene C. (2) A representação do sistema como uma rede e (3) o grafo codificado numa matriz de adjacências. Na matriz, quando existe uma aresta entre um par de vértices a célula correspondente recebe o valor 1 , caso contrário recebe o valor 0 . Por exemplo, a primeira linha codifica as arestas de $A$ para $B$ e de $A$ para $C$.

A proteína $\mathrm{TF}-\mathrm{B}$ forma um complexo com $\mathrm{o} \mathrm{TF}-\mathrm{A}$ que, juntos, ligam-se à região promotora do gene-TF-C. Note que ambos são necessário para que o gene-TF-C seja expresso. O transcrito do gene-TF-C é então traduzido na proteína $\mathrm{TF}-\mathrm{C}$. Esta proteína liga-se à região promotora do gene-TF-A, criando um reforço positivo à transcrição do sistema.

Note que não há uma interação direta entre TF-A e TF-C. Se fosse possível observar interação proteína-proteína, um relacionamento entre $\mathrm{TF}-\mathrm{A}$ e $\mathrm{TF}-\mathrm{C}$ não seriam observados. No entanto, há uma relação entre as concentrações dos transcritos gene-TF-A e gene-TF-C. À medida que aumenta a concentração de transcrito gene-TF-C, há consequente aumento na concentração de proteína $\mathrm{TF}-\mathrm{C}$, o que por sua vez induz a um aumento na concentração de transcrito gene-TF-A. A relação negativa também é verdadeira, isto é, havendo diminuição na concentração do transcrito gene-TF-C, haverá redução na concentração de transcrito gene-TF-A. Na Figura 2.2, esta relação é representada no grafo (quadro 2) pelas arestas entre os vértices A para $\mathrm{C}$ e de $\mathrm{C}$ para $\mathrm{A}$.

Com relação aos genes gene-TF-A e gene-TF-B, note que além de haver uma relação entre a concentração de transcrito, há também uma interação proteína-proteína. Quando aumenta a concentração do transcrito gene- $\mathrm{TF}-\mathrm{A}$, aumenta a da proteína $\mathrm{TF}-\mathrm{A}$ e em seguida a concentração do transcrito gene-TF-B e a consequente tradução da proteína $T F-B$. Sem a interação proteína-proteína de $\mathrm{TF}-\mathrm{A}$ e $\mathrm{TF}-\mathrm{B}$ não há transcrição de gene-TF-C. Esta estrutura na qual $\mathrm{A}$ regula $\mathrm{B}$ e ambos regulam um terceiro gene $\mathrm{C}$ é conhecida como feed forward loop network motif [Mangan e Alon, 2003]. A semântica da estrutura é que a resposta a um estímulo externo para ligar a transcrição de $\mathrm{C}$ é mais lenta que para desligar. Em outras palavras, para transcrever $\mathrm{C}$ é necessário primeiro transcrever A, em seguida transcrever B e só então transcrever C. Para parar a transcrição de C basta que A ou B sejam inibidos. Outra questão importante é que, como há um delay entre a transcrição de A e C, pode não haver correlação alta entre seus respectivos perfis de expressão. Como será visto adiante, a expressão do par de prediores A e B deve ter uma correlação 
maior com $\mathrm{C}$ quando observados juntos do que quando observados isoladamente. É também neste sentido que o dado da interação proteína-proteína pode contribuir para melhorar a inferência de GNs.

O cenário complexo da Figura 2.2 no (quadro 1) pode ser modelado como um grafo (quadro 2). O grafo por sua vez pode ser representado como uma matriz de adjacências (quadro 3).

Para a inferência de redes gênicas é importante assumir um modelo de geração dos dados observados. Há diferentes modelos, alguns deles são apresentados a seguir.

\subsection{Modelagem de Redes Gênicas}

\subsubsection{Redes Booleanas}

As Redes Booleanas (BNs, do inglês Boolean Networks) tiveram origem no trabalho de Kauffman [Kauffman, 1969] para a modelagem de GNs. Um dos objetivos deste trabalho seminal foi explorar a dinâmica de sistemas complexos na forma de redes [Lopes, 2011]. Formalmente, uma Rede Booleana é definida com $n$ vértices (genes): $x_{1}, x_{2}, \ldots, x_{n}$. Cada vértice assume um valor binário: $x_{i}=0$ (OFF) ou $x_{i}=1(\mathrm{ON})$. Cada vértice $x_{i}$ possui um conjunto de $k_{i}$ genes reguladores e cada vértice usa uma função booleana $f_{i}$ para definir seu valor, isto é:

$$
x_{i}(t+1)=f_{i}\left(x_{1}(t), x_{2}(t), \ldots, x_{k_{i}}(t)\right)
$$

Assim, o valor de cada gene regulador de $x_{i}$ no instante de tempo presente é usado para calcular o valor de $x_{i}$ no tempo seguinte. Este processo chama-se atualização. A atualização pode ser síncrona ou assincrona. Em uma atualização síncrona todas as variáveis têm seus valores alterados simultaneamente. Como exemplo, com base no cenário da Figura 2.2, assuma que os genes A, B e C são representados pelas variáveis $x_{1}, x_{2}, x_{3}$, respectivamente. Considere também as seguintes funções booleanas:

$$
\begin{aligned}
& x_{1}(t+1)=f_{1}\left(x_{3}(t)\right)=x_{3} \\
& x_{2}(t+1)=f_{2}\left(x_{1}(t)\right)=x_{1} \\
& x_{3}(t+1)=f_{3}\left(x_{1}(t), x_{2}(t)\right)=x_{1} \text { and } x_{2}
\end{aligned}
$$

Estas funções codificam a relação entre os genes da Figura 2.2 de modo que $x_{1}$ depende diretamente de $x_{3}, x_{2}$ de $x_{1}$ e $x_{3}$ só será transcrito (terá valor 1 ) quando $x_{1}$ e $x_{2}$ forem iguais a 1.

Outro conceito importante é o de estado do sistema. O estado do sistema em um dado instante de tempo $t$ é um vetor composto pelos valores binários de todos os vértices:

$$
s(t)=\left\{x_{1}(t), x_{2}(t), \ldots, x_{n}(t)\right\}
$$

O número de estados possíveis de uma Rede Booleana é dado por $2^{n}$, onde $n$ é o número de vértices (ou genes na modelagem de GNs). Por exemplo, em uma Rede Booleana com três genes, existem $2^{3}=8$ estados possíveis: 000,001,010,011,100,101,110,111. Na função booleana definida 


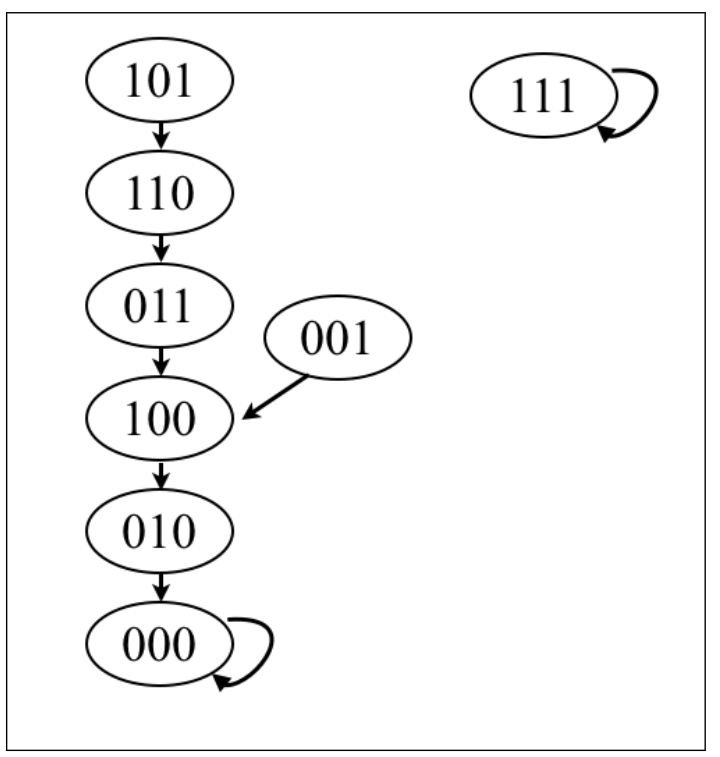

Figura 2.3: Bacias de atração. Todas as transições possíveis da Rede Booleana. Duas bacias de atração sendo a maior com 7 estados e a menor com um único estado.

na Equação 2.1 o valor do gene $x_{i}$ no instante de tempo $t+1$ é uma função de todos os seus genes reguladores no tempo $t$.

Por exemplo, supondo um estado inicial $s(1)=\{1,0,0\}$ e considerando uma atualização síncrona, no instante seguinte $x_{1}(2)=x_{3}(1)=0, x_{2}(2)=x_{1}(1)=1$ e $x_{3}(2)=x_{1}(1)$ and $x_{2}(1)=$ 1 and $0=0$, isto é, $s(2)=\{0,1,0\}$. Aplicando novamente a função $s(3)=\{0,0,0\}$. A partir deste último estado, qualquer outra transição levará ao estado $s(l)=\{0,0,0\}$ para qualquer $l>3$.

Uma vantagem de utilizar-se modelos booleanos é que os valores de expressão são discretizados e, como consequência, o número de estados que o sistema pode assumir é finito, i.e., $2^{n}$. Uma rede modelada como uma Rede Booleana determinística possui algumas propriedades de interesse que podem caracterizar o comportamento de seus componentes e a interação entre eles:

i As transições entre estados formarão ciclos em algum instante;

ii atratores são um conjunto de estados que formam um ciclo em alguma sequência de estados como o estado $\{0,0,0\}$ do exemplo anterior (um atrator com um único estado);

iii todos os estados conduzem a um atrator ou são parte de um atrator;

iv o conjunto de todos os estados que levam a um dado atrator mais os estados do atrator formam uma bacia de atração;

v uma dada topologia pode gerar de uma a várias bacias de atração. No mínimo uma bacia e no máximo $2^{n}$ (bacias com atratores de tamanho 1);

vi atratores correspondem a estados em que um sistema tende a permanecer;

vii grandes bacias de atração correspondem a sistemas com alta estabilidade;

viii as bacias de atração fornecem uma idéia da dinâmica do sistema. 
A Figura 2.3 mostra todas as transições de estado possíveis para a rede da Figura 2.2, modelada com as funções booleanas apresentadas acima. Há duas bacias de atração, uma com sete estados e uma com um único estado. Na bacia maior, se o sistema começar em qualquer um dos estados, aplicando-se a função booleana sucessivas vezes, terminará sempre no estado $\{0,0,0\}$, que é o atrator de tamanho 1. Na bacia menor, permanecerá no estado $\{1,1,1\}$.

\subsubsection{Redes Booleanas Probabilísticas - PBNs}

Em uma Rede Booleana Probabilística (PBN, do inglês Probabilistic Boolean Networks) [Shmulevich et al., 2002a,b], existe uma probabilidade de transição entre quaisquer estados do sistema. Um critério pode ser usado para diferenciar as transições que ocorreriam em uma Rede Booleana (transições mais prováveis) de outras transições (menos prováveis). Como exemplo de um modelo deste tipo, veja-se a rede apresentada nas publicações de [Li et al., 2004, Zhang et al., 2006]. Neste modelo, a função de transição de cada gene $i$ é dada por uma função $\Upsilon$ de suas entradas da seguinte forma:

$$
\Upsilon_{i}(t)=\sum_{j} a_{j, i} \cdot x_{j}(t)
$$

Onde $a_{i, j}$ é 1 se o gene $j$ ativa o gene $i,-1$ se inibe e 0 se não há relação entre eles. Em outras palavras, $\Upsilon_{i}(t)$ é a soma dos valores dos genes de entrada de $x_{i}$, ponderada pelos pesos das arestas (-1,0 ou 1). O valor de $x_{i}$ no instante $t+1$ é definido da seguinte forma:

$$
x_{i}(t+1)=\left\{\begin{array}{cc}
1, & \text { se } \Upsilon_{i}(t)>0 \\
0, & \text { se } \Upsilon_{i}(t)<0 \\
x_{i}(t), & \text { se } \Upsilon_{i}(t)=0
\end{array}\right.
$$

No artigo referido, a probabilidade do estado de $x_{i}$ no tempo $t+1$ é dada de modo que:

$$
\begin{aligned}
& \text { Se } \Upsilon_{i}(t)>0 \text { então, } \\
& P\left(x_{i}(t+1)=1 \mid x_{1}(t), x_{2}(t), \ldots, x_{n}(t)\right) \approx 1 \\
& P\left(x_{i}(t+1)=0 \mid x_{1}(t), x_{2}(t), \ldots, x_{n}(t)\right) \approx 0
\end{aligned}
$$

Se $\Upsilon_{i}(t)<0$ então,

$$
\begin{aligned}
& P\left(x_{i}(t+1)=1 \mid x_{1}(t), x_{2}(t), \ldots, x_{n}(t)\right) \approx 0 \\
& P\left(x_{i}(t+1)=0 \mid x_{1}(t), x_{2}(t), \ldots, x_{n}(t)\right) \approx 1
\end{aligned}
$$

Se $\Upsilon_{i}(t)=0$ então,

$$
\begin{aligned}
& P\left(x_{i}(t+1)=x_{i}(t) \mid x_{1}(t), x_{2}(t), \ldots, x_{n}(t)\right) \approx 1 \\
& P\left(x_{i}(t+1) \neq x_{i}(t) \mid x_{1}(t), x_{2}(t), \ldots, x_{n}(t)\right) \approx 0
\end{aligned}
$$

Assim, o estado do sistema no tempo $t+1$ é dado em função do estado do sistema no tempo anterior. A probabilidade de transição de estados na Rede Booleana é calculada conforme a Equação 
2.9 .

$$
P\left(x_{1}(t+1), \ldots, x_{n}(t+1) \mid x_{1}(t), \ldots, x_{n}(t)\right)=\prod_{i=1}^{n} P\left(x_{i}(t+1) \mid x_{1}(t), \ldots, x_{n}(t)\right)
$$

Não se espera que em um sistema como o sistema biológico as transições entre estados sejam determinísticas. Portanto, é importante supor que há uma chance (ainda que mínima) de transições para qualquer estado.

A Figura 2.4 mostra o que seria um exemplo de transições permitidas em uma PBN, do estado $\{1,1,1\}$ para todos os demais. Na BN o estado $\{1,1,1\}$ só possui a transição para ele próprio (indicada pela aresta contínua) na Figura 2.3. Na PBN do artigo de exemplo citado, haveria uma probabilidade de transição próxima de 1 para o estado $\{1,1,1\}$, mas também haveria probabilidade de transição próxima de 0 do estado $\{1,1,1\}$ para todos os demais.

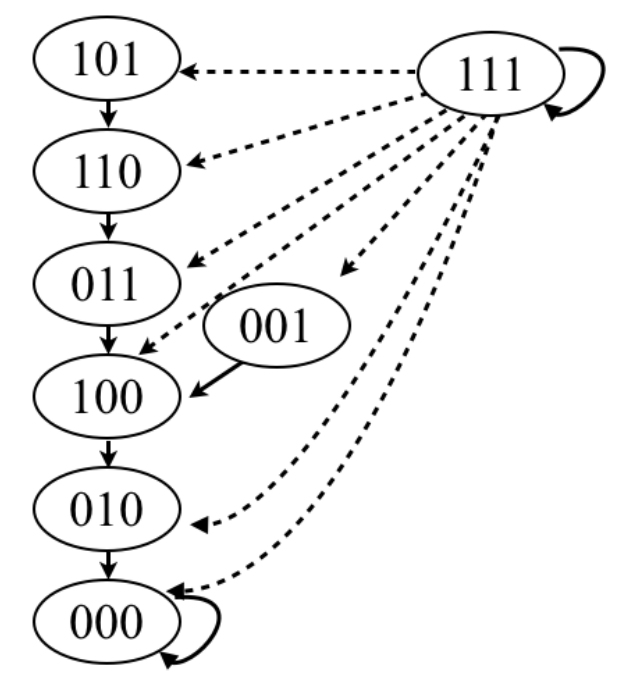

Figura 2.4: Transições de Estados entre o estado $\{1,1,1\}$ e os demais em uma Rede Booleana Probabilística. As linhas contínuas ilustram as transições de maior probabilidade, e as linhas pontilhadas as transições de menor probabilidade tendo o estado $\{1,1,1\}$ como origem. Há transição entre todos os estados do sistema, mas a figura destaca apenas as transiçôes adicionadas ao estado $\{1,1,1\}$. 


\subsubsection{Redes Gênicas Probabilísticas - PGNs}

Como apresentado na Seção 1.1, a regulação transcricional envolve um sistema complexo de sinalização no qual a transcrição exerce um papel fundamental. Os genes são primeiro transcritos pela atuação de proteínas reguladoras e após isto, são traduzidos em proteínas (reguladoras ou não) e então podem atuar regulando a expressão gênica. Em outras palavras, a expressão de cada gene em um dado instante de tempo depende da sua própria transcrição e da transcrição de outros genes em tempo anterior.

Neste sentido, a PGN (do inglês, Probabilistic Genetic Network) de [Barrera et al., 2004, 2007] modela a rede complexa celular como um sistema dinâmico, discreto no tempo, no qual o estado do sistema num dado instante de tempo é dado em função do estado do sistema em instante de tempo anterior.

Com o fim de formalizar o modelo, serão introduzidas algumas definições. Seja $R$ o conjunto de valores para todo componente do sistema. Por exemplo $R=\{0,1\}$ poderia representar um gene como desligado (0) ou ligado (1). Ou ainda, poderia representar o nível transcricional do gene como sub-expresso, transcrição basal e super-expresso, fazendo $R=\{-1,0,1\}$.

Cada gene $i$ é uma variável que assume um valor $x_{i} \in R$. O conjunto de todas estas variáveis formam um vetor de estado do sistema. Deste modo, o vetor $x(t) \in R^{n}$ representa o estado do sistema composto por $n$ genes no instante e tempo $t$. Cada gene no vetor de estado está associado a uma função que computa seu valor com base no estado anterior. O conjunto de todas estas funções formam um vetor chamado função de transição.

$$
x(t+1)=\phi(x(t))
$$

onde $x(t) \in R^{n}, \forall t \geq 0$.

Em outras palavras, a função de transição mapeia o estado presente no próximo. O sistema é invariante quanto a translação no tempo, isto é, a função de transição não muda com o tempo.

Assim, a função de transição $\phi$, para uma rede gênica com $n$ genes é uma função $R^{n} \rightarrow R^{n}$ que define a transição de estados do sistema.

Na PGN, a função $\phi$ é estocástica e definida como um caso particular de Cadeia de Markov.

Considerando uma sequência de vetores aleatórios $X_{0}, X_{1}, \ldots$, assumindo valores em $R^{n}$ e a sequência de estados aleatórios $\left(X_{t}\right)_{t=0}^{\infty}$, denotado respectivamente $x(0), x(1), \ldots$ é uma Cadeia de Markov se, para todo $t \geq 1, P\left(X_{t}=x(t) \mid X_{0}=x(0), \ldots, X_{t-1}=x(t-1)\right)=P\left(X_{t}=x(t) \mid X_{t-1}=\right.$ $x(t-1))$. O significado da Cadeia de Markov neste contexto é que a probabilidade condicional do estado no tempo $t$, dados todos os eventos anteriores (i.e. de 0 até $t-1$ ), depende apenas do estado imediatamente anterior (tempo $t-1$ ).

A Cadeia de Markov é caracterizada por uma matriz de transição de estados $\pi_{Y \mid X}$ de probabilidades condicionais entre os estados do sistema. Cada elemento da matriz de transição é denotado por $p_{Y \mid X}$. O estado inicial é denotado por $\pi_{0}$.

Assim, a PGN é uma Cadeia de Markov $\left(\pi_{Y \mid X}, \pi_{0}\right)$ que assume os seguintes axiomas:

(a) $p_{Y \mid X}$ é não é uma função de $t$. Isto é, a matriz de transição $\pi_{Y \mid X}$ é homogênea, não muda com o tempo.

(b) $p_{Y \mid X}>0$ para todo estado $x, y \in R^{n}$. Isto significa que todos os estados podem ser atingidos. 
(c) $\pi_{Y \mid X}$ é condicionalmente independente, isto é para cada estado $x, y \in R^{n}, p_{Y \mid X}=\prod_{i=1}^{n} p\left(y_{i} \mid x\right)$

(d) $\pi_{Y \mid X}$ é quase determinístico. Para cada estado $x \in R^{n}$ há um estado com probabilidade de transição próxima de 1.

\subsection{Seleção de Características, Busca e Função Critério}

Segundo Duda [Duda et al., 2000] o reconhecimento de padrões é "o ato de obter dados brutos e tomar uma ação baseado na categoria do padrão". De acordo com Bishop [Bishop, 2006] o campo de reconhecimento de padrões relaciona-se com a descoberta automática de regularidades em dados e do uso destas regularidades para tomar ações tais como a classificação dos dados em diferentes categorias. O reconhecimento de padrões permite classificar um objeto, associando-o a uma classe com base em um subconjunto de suas características.

O design de um sistema de reconhecimento de padrões envolve algumas etapas [Duda et al., 2000] conforme ilustrado na Figura 2.5.

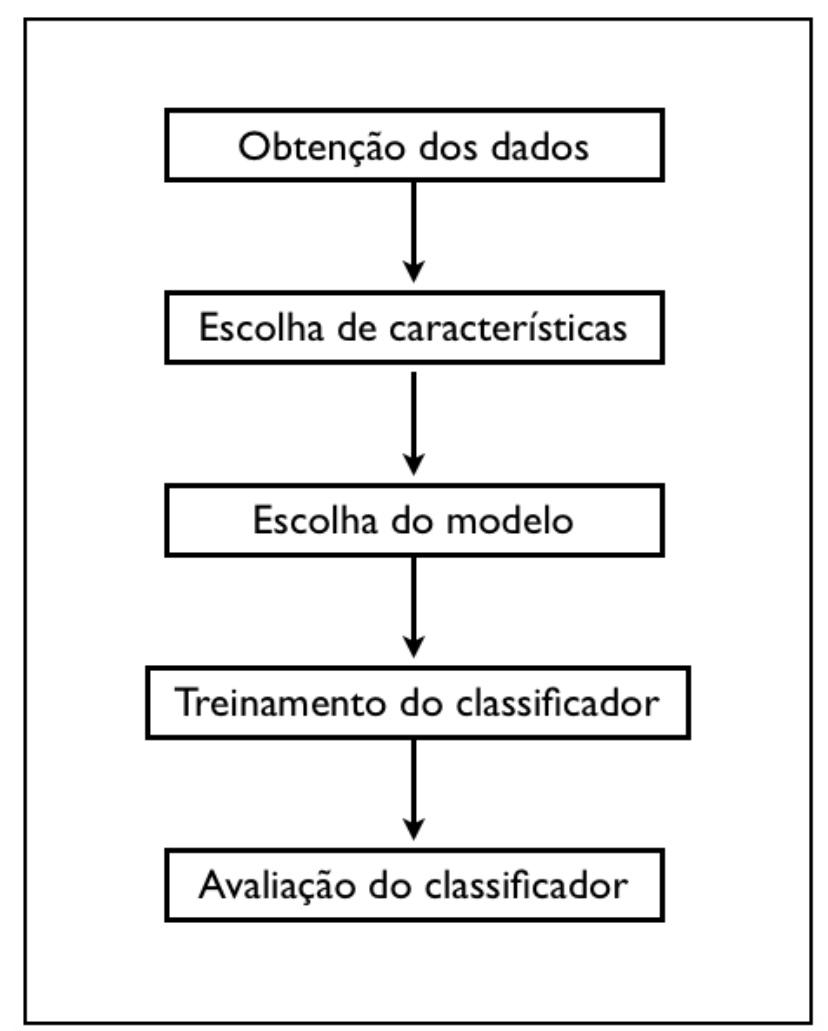

Figura 2.5: Adaptado de [Duda et al., 2000]. Etapas do design de um sistema de reconhecimento de padrões.

A obtenção de dados consiste no levantamento sobre a diversidade de dados possíveis de se obter sobre o objeto a ser classificado. Também leva em conta a quantidade destes dados e o questionamento sobre a representatividade do conjunto de exemplos para treinamento e teste. A escolha de características consiste em identificar um subconjunto de características que seja adequado para classificar os objeto. Há diferentes maneiras de realizar a classificação. Esta etapa consiste em escolher um modelo. O treinamento consiste em utilizar uma parte dos dados para determinar o classificador. Finalmente, a etapa de avaliação é importante para mediar a acurácia do sistema. 
A escolha de características é uma etapa crucial. Dado um conjunto de classes $\Omega=\omega_{1}, \omega_{2}, \ldots, \omega_{n}$, os objetos serão atribuídos a uma classe conforme os valores de suas $m$ características $X=$ $\left(x_{1}, x_{2}, \ldots, x_{m}\right)$. Assim, é importante identificar quais características são adequadas para classificar os padrões. Segundo Duda [Duda et al., 2000], a escolha das características pode estar baseada no conhecimento prévio do problema. A escolha de características naturalmente tenderá a optar por aquelas que sejam simples de extrair, invariantes a transformações irrelevantes, insensíveis a ruídos e úteis para discriminar padrões.

Outro aspecto importante relacionado às características trata-se da redução de dimensionalidade. É comum que a dimensão do espaço de características seja muito grande (como na inferência de GNs, por exemplo), o que dificulta a classificação. Assim, dado um conjunto de medidas, a redução de dimensionalidade pode ser obtida basicamente de duas formas: a primeira é a identificação das variáveis que não contribuem para a classificação, isto é, optar por descartar aquelas variáveis que não separam bem as classes [Webb e Copsey, 2011]. Isto é chamado de seleção de características. Uma outra abordagem consiste em transformar o conjunto de medidas do objeto em um espaço de característica de tamanho menor. Esta abordagem é chamada de extração de características.

A "maldição da dimensionalidade" [Bishop, 2006, Jain et al., 2000] é um problema relacionado ao crescimento exponencial do número de amostras necessárias para classificação em relação ao número de características selecionadas. Na inferência de redes de genes a partir de dados de expressão, por exemplo, o número de genes é da ordem de dezenas de milhares e o número de amostras de expressão é da ordem de dezenas. Neste sentido, a redução de dimensionalidade se torna importante. Segundo Webb [Webb e Copsey, 2011], as razões para realizar seleção de características incluem: (a) aumentar a acurácia preditiva de um classificador, (b) remover variáveis irrelevantes, (c) melhorar a eficiência, (d) reduzir o custo de aquisição de dados, (e) reduzir a complexidade da descrição do classificador resultante.

No caso da inferência de redes gênicas abordada neste trabalho, cada gene é modelado como uma variável que assume um valor discreto de expressão. De forma geral, o problema consiste em identificar, para cada gene alvo, o subconjunto de genes (características) que melhor classifique o valor de expressão do gene alvo.

A seleção de características consiste em duas partes: (a) a definição de uma função critério, utilizada para medir a qualidade de um subconjunto de características e (b) um método de busca, utilizado para selecionar o subconjunto de características. O algoritmo de busca pode ser ótimo ou sub-ótimo. O algoritmo ótimo retorna o melhor subconjunto, isto é, o subconjunto de valor ótimo segundo a função critério adotada. Uma busca exaustiva espaço de características exige que se avalie todos os subconjuntos. Por exemplo, na inferência de redes gênicas, para uma rede com $n$ genes, seria necessário testar todas as possíveis combinações de $n$ genes tomados $k$ a $k$, com $k$ variando de 1 a $n-1$, por exemplo. Assim, o método exaustivo é comumente inviável na inferência de redes onde $n$ é geralmente da ordem de milhares. Deste modo, os métodos sub-ótimos geralmente são adotados neste tipo de problema. Este trabalho adota um algoritmo sub-ótimo da categoria dos algoritmos de busca sequencial. Num algoritmo de busca sequencial as características são adicionadas ou removidas sequencialmente. Embora estes métodos não sejam ótimos, são mais rápidos e simples de implementar, além de possibilitarem resultados satisfatórios. Para explicar o algoritmo adotado neste trabalho serão apresentados a seguir dois outros algoritmos que o compõem. 


\subsubsection{SFS - Sequential Forward Selection}

O algoritmo de busca sequencial para frente, ou método de adição de conjunto, é um procedimento de busca bottom-up que sempre adiciona novas características ao conjunto [Webb e Copsey, 2011]. O algoritmo parte de um subconjunto de características nulo e a cada etapa adiciona uma nova característica de modo que o valor da função critério seja maximizado. Quando a adição da melhor característica piora o valor da função critério ou quando atinge-se o número máximo de características, o algoritmo pára. A principal desvantagem deste método é que não é possível remover uma característica já que trata-se de um método de adição.

\subsubsection{SBS - Sequential Backward Selection}

O algoritmo de busca sequencial para trás, ou deleção sequencial para trás (do inglês, sequential backward elimination), faz o oposto do SFS. É um procedimento top-down no qual inicia com o conjunto completo de características e deleta uma por vez até que um subconjunto de uma dada cardinalidade seja atingido. A desvantagem em relação ao SFS é que a função critério deve avaliar conjuntos maiores de variáveis, o que aumenta a demanda computacional.

\subsubsection{SFFS - Sequential Forward Floating Selection}

O algoritmo SFFS faz uma busca flutuante, isto é, permite a inclusão e exclusão de características utilizando dos dois métodos apresentados acima como etapas do algoritmo. O algoritmo inicia com um subconjunto nulo e aplica o algoritmo SFS até atingir subconjunto de tamanho $k=$ 2. Posteriormente alterna entre o algoritmo SBS e SFS para remover e adicionar características, respectivamente, de acordo com a melhora no valor da função critério em cada etapa.

Suponha que numa dada etapa $k$ existam $k$ subconjuntos $X_{1}, X_{2}, \ldots, X_{k}$ de tamanhos 1 a $k$, respectivamente, com valores de Função Critério $F\left(X_{i}\right)=F_{i}, i=1, \ldots, k$. Na k-ésima etapa, o algoritmo faz como segue:

i Selecione a característica $x_{j}$ (ainda não adicionada) que maximize o valor de $F$.

ii Adicione a característica $x_{j}$ ao conjunto $X_{k+1}=\left\{X_{k}, x_{j}\right\}$

iii Remove condicionalmente a característica. Encontre a característica $x_{q}$ no conjunto $X_{k+1}$ que reduza ao máximo o valor da função critério. Se $x_{q}$ é $x_{j}$, faça $k \leftarrow k+1$ e volte ao passo (i), senão, remova $x_{q}$ do conjunto, obtendo um novo conjunto $X_{k}^{0}$.

iv Remova características de $X_{k}^{0}$ enquanto $F\left(X_{k-1}^{0}\right)>F_{k-1}$; Faça $k \leftarrow k-1$; volte ao passo (i).

\subsection{Inferência de Redes}

A inferência de Redes Gênicas consiste em reconstruir a rede de interações que teria gerado os dados de expressão observados [Baralla et al., 2009, Dougherty e Bittner, 2010, Karlebach e Shamir, 2008, Lopes et al., 2014b, Shmulevich e Dougherty, 2002]. Assim, é necessário uma forma de avaliar as interações possíveis e selecionar aquelas que melhor correspondam aos dados de expressão. Este processo também é conhecido como engenharia reversa. 
É importante que a rede inferida tenha correspondência com o aspecto biológico, isto é, que a escolha das interações pelo algoritmo de inferência esteja fundamentada no modelo biológico conhecido. Há dois problemas principais a serem tratados na inferência de redes: percorrer o espaço de busca para encontrar uma solução ótima ou sub-ótima e definir uma função critério para medir a qualidade da solução (veja Seção 2.5). Tratando-se em particular da inferência de redes de genes, o espaço de busca é geralmente enorme. No caso do modelo adotado neste trabalho, onde para cada gene alvo busca-se um subconjunto de genes reguladores, seria necessário testar para cada um dos genes alvo, todas as combinações dos $N$ genes restantes da rede tomados $k$ a $k$ (com $k$ variando de 1 até $N$ ). O crescimento é exponencial. Portanto, a adoção de um algoritmo de busca sub-ótimo se faz necessária. Para lidar com o problema do espaço de busca, utiliza-se de estratégias de busca como o SFS, SBS e SFFS, por exemplo, dado que a abordagem exaustiva é inviável para redes grandes. Métodos baseados no algoritmo SFFS foram propostos em [Lopes et al., 2008c, 2010, 2011, Vicente e Lopes, 2014]. Na inferência de genes, uma solução corresponde a um subconjunto de genes preditores para um dado gene alvo. Em outras palavras, um conjunto de variáveis a partir das quais, observando seu estado em um instante de tempo $t$ pode-se prever o estado do gene alvo no instante $t+1$.

Com respeito à função critério, há diferentes abordagens adotadas na inferência de redes gênicas. Em qualquer abordagem, a medida da qualidade da solução sempre levará em conta algum tipo de relação entre os dados de expressão. Dentre as abordagens pode-se citar como principais: (a) inferência de relações par a par em redes de co-expressão baseadas em medidas de correlação e (b) correlação parcial, (c) coeficiente de determinação e (d) medidas de teoria da informação [Wang e Huang, 2014].

No caso de redes booleanas, os dados são discretizados em intervalos binários (0 e 1). Porém, é possível discretiza-los em mais intervalos como por exemplo (-1, 0 e 1) como na PGN (veja Seção 2.4.3).

\subsubsection{Correlação}

As funções baseadas em correlação permitem avaliar interações entre pares de genes, isto é, relacionamentos do tipo 1-para-1. O aspecto biológico que fundamenta analisar a correlação entre os valores do perfil de expressão é que genes que interagem na regulação da transcrição um do outro, devem ter padrões de expressões similares ou correlacionados. Portanto, encontrar estas relações é um meio de identificar quais, dentre milhares de genes, possivelmente possuem alguma interação biológica. Usando a correlação como função critério é possível portanto inferir uma rede gênica na qual as arestas correspondem a uma relação entre a expressão dos genes e indicam a possibilidade de uma interação biológica entre eles [D'haeseleer et al., 2000].

Medidas de correlação como de Pearson e Spearman são úteis para identificar co-regulação e coexpressão. A correlação pode ser de ordem zero, na qual apenas um par de variáveis é considerado. Adota-se um limiar para o valor da correlação a partir do qual uma aresta é adicionada entre o par de genes. Este tipo de função tende a gerar muitos falsos positivos, especialmente quando se deseja encontrar relacionamentos entre fatores de transcrição e seus alvos. Por exemplo quando dois genes são regulados pelo mesmo TF, se seus perfis de expressão forem similares por causa da ação do TF, a correlação deve indicar um relacionamento entre os dois genes alvo. Neste caso adota-se como funções critério correlação de primeira ordem e correlação de segunda ordem, nas quais se analisa 
a correlação entre duas variáveis $x, y$ condicionadas a uma terceira variável $z$ ou terceira e quarta $z q$, respectivamente [de la Fuente et al., 2004]. Neste tipo de inferência, quando uma correlação de primeira ou segunda ordem explicam a relação entre um par de variáveis $x, y$, a aresta entre elas é removida. Esta abordagem diminui o número de falsos positivos quando o interesse é inferir uma rede de regulação transcricional. Na inferência usando correlação os grafos são não dirigidos, isto é, não é possível sugerir uma causalidade entre as variáveis, apenas é possível indicar que há uma relação entre o par de genes.

\subsubsection{Coeficiente de Determinação}

O coeficiente de determinação (CoD, do inglês Coefficient of Determination) [Hashimoto et al., 2004] é baseado na estimação do erro Bayesiano de classificar o valor de um gene alvo, dado um conjunto de genes preditores. $\mathrm{O} \mathrm{CoD}$ mede o grau com que um conjunto de variáveis melhora a predição de uma variável alvo com relação à melhor predição a priori [Ghaffari et al., 2010].

Seja $\mathbf{X}$ o conjunto de variáveis, $Y$ a variável alvo e a função $f(\mathbf{X})$ preditor de $Y$, definida no caso booleano, tal que

$$
f(\mathbf{x})= \begin{cases}1, & \text { se } P(Y=1 \mid \mathbf{X}) \geq 0,5 \\ 0, & \text { se } P(Y=1 \mid \mathbf{X})<0,5\end{cases}
$$

Seja $\epsilon(Y, \mathbf{X})$ o erro quadrático médio mínimo sobre todo $f(\mathbf{X})$, e $\epsilon_{0}(Y)$ o erro do melhor estimador de $Y$ na ausência de variáveis condicionais $\mathbf{X}$. O coeficiente de determinação é definido como:

$$
C o D(Y, \mathbf{X})=\frac{\epsilon_{0}(Y)-\epsilon(Y, \mathbf{X})}{\epsilon_{0}(Y)}
$$

Deste modo, o CoD permite estimar relacionamentos entre um grupo de preditores e um gene alvo, num relacionamento N-para-1.

\subsubsection{Teoria da Informação: Entropia e Informação Mútua}

O conceito de entropia surgiu inicialmente na área da termodinâmica com Clausius [Clausius, 1879] e posteriormente com Boltzmann [Boltzmann, 1974], que a definiu em termos das probabilidades de configurações de um sistema. A Entropia de Boltzmann-Gibbs de um sistema com $W$ configurações microscópicas possíveis é dada pela equação [Tsallis, 1988]:

$$
H_{B G}(X)=-k \sum_{i=1}^{W} p_{i} \times \log \left(p_{i}\right),
$$

onde

$$
\sum_{i=1}^{W} p_{i}=1
$$

Na equação, $k$ é chamada constante de Boltzmann e $p_{i}$ é a probabilidade de cada uma das $W$ configurações do sistema.

A Entropia de Shannon [Shannon e Weaver, 1963] pode ser vista como uma forma de associar uma medida de incerteza a uma variável aleatória $X$, e é definida pela média ponderada dos 
logaritmos das probabilidades de $X$ conforme a equação:

$$
H(X)=-\sum_{x \in X} P(x) \times \log (P(x))
$$

onde

$$
\sum_{x \in X} P(x)=1
$$

Na teoria da informação o logaritmo tem base igual a dois e assume-se que $0 \times \log (0)=0$. Assim, a entropia indica quanta informação é recebida quando observada a variável. Segundo Bishop [Bishop, 2006], a quantidade de informação está associada ao "grau de surpresa" em observar o valor de uma variável aleatória $x$. Se a observação de $x$ indica que um evento muito improvável ocorreu, haverá mais informação do que se $x$ indicar um evento sem surpresas. Por exemplo se $X$ assumir apenas dois valores $(0$ e 1$)$ e as probabilidades forem $P(x=0)=0,5$ e $P(x=1)=0,5$, a entropia será máxima: $H(X)=1$. Visto que a distribuição de $P(X)$ neste caso é uniforme, a medida de incerteza é máxima. Ao contrário, se por exemplo $P(x=0)=0.9$ e $P(x=1)=0.1$ a entropia seria menor: $H(X)=0.18$, indicando uma incerteza menor. Assim, quanto menor a entropia, maior o grau de certeza em predizer o valor da variável.

A entropia conjunta de duas variáveis $x, y$ calculada a partir da probabilidade conjunta $P(x, y)$ é dada por:

$$
H(X, Y)=-\sum_{x \in X, y \in Y} P(x, y) \times \log (P(x, y))
$$

Em alguns casos é possível associar uma medida de incerteza a uma variável aleatória $Y$ após a observação de outra variável aleatória $X$. Por exemplo, o valor (de expressão) de um gene alvo $Y$ após a observação do valor de um outro gene $X$. Neste caso é chamada de entropia condicional. A entropia condicional de $Y$ dado $x$ é dada por:

$$
H(Y \mid x)=-\sum_{y \in Y} P(y \mid x) \times \log (P(y \mid x)),
$$

onde $P(y \mid x)$ é a probabilidade condicional e $P(y, x)$ é a probabilidade conjunta das variáveis $X$ e $Y$.

A Entropia Condicional Média (MCE, do inglês Mean Conditional Entropy) [Lopes et al., 2008c] é a média ponderada de $H(Y \mid x)$ para cada $x \in X$ :

$$
H(Y \mid X)=\sum_{x \in X} H(Y \mid x) \times P(x)
$$

Quanto maior a MCE, maior a incerteza em prever o estado da variável $Y$ pela observação de $X$. E no sentido oposto, quanto menor a $M C E$, menor a incerteza de prever o estado da variável $Y$ pela observação de $X$. Neste sentido, a MCE pode servir como função critério, para selecionar um conjunto de variáveis $X$ que melhor predizem o estado de uma variável alvo $Y$. No contexto da inferência de GNs, o objetivo é selecionar um conjunto de genes $X$ (preditores) que permitam predizer o valor de um gene alvo $Y$ com menor incerteza possível. 
Por causa do problema do baixo número de amostras e da maldição da dimensionalidade (veja Seção 2.5) é comum que existam instâncias não observadas das variáveis aleatórias [Dougherty e Bittner, 2010, Shmulevich e Dougherty, 2002, Yu et al., 2008]. Assim, uma alteração na equação $M C E$, oferece uma função critério que inclui uma penalização das instâncias não observadas [Lopes et al., 2008c]:

$$
H(Y \mid X)=\frac{\gamma(T-S) H(Y)+\sum_{i=1}^{S}\left(f_{i}+\gamma\right) H\left(Y \mid X=x_{i}\right)}{\gamma T+D}
$$

onde $T$ é o total de amostras possíveis, $S$ é o número de amostras observadas, $D$ é o número de amostras temporais do dado de expressão, $f_{i}$ é a frequência absoluta de $x_{i}$ e $\gamma$ é um parâmetro para determinar o peso da penalização. No contexto da inferência de redes, quanto maior a cardinalidade de $X$, isto é, quanto maior o conjunto de preditores, maior a chance de não observação de uma instância de $X$, portanto, maior a penalização. Neste sentido, esta função critério tende a favorecer conjuntos com cardinalidade menor, dependendo da quantidade de dados disponíveis e da quantidade de instâncias observadas em conjuntos maiores.

\section{Informação Mútua}

A informação mútua é uma função baseada na teoria da informação que mede a quantidade de informação compartilhada entre duas variáveis [Gray, 1990]. Algumas abordagens utilizam a informação mútua como função critério para inferir a GN como o algoritmo REVEAL(general REverse Engineering ALgorithm) [Liang et al., 1998].

A informação mútua é calculada a partir da entropia e da entropia condicional de duas variáveis aleatórias:

$$
M(X, Y)=H(X)-H(X \mid Y)=H(Y)-H(Y \mid X)
$$

A idéia do algoritmo é que se a informação compartilhada entre o subconjunto $X$ e a variável alvo $Y, M(X, Y)$, for igual a $H(Y)$, significa que $X$ é responsável pelo comportamento de $Y$. Assim, o algoritmo utiliza a informação mútua para buscar por subconjuntos de preditores que satisfaçam $M(X, Y)=H(Y)$.

\subsection{Redes complexas e características topológicas}

Sistemas naturais formam redes complexas de interações. Segundo [Albert e Barabási, 2002, Easley e Kleinberg, 2012, Latora e Marchiori, 2001], vivemos em um universo onde diversos fenômenos naturais podem ser vistos como redes complexas. Estes sistemas são tanto biológicos e naturais como não naturais como a Internet, redes sociais, sistemas físicos, a dinâmica de propagação de infecções, redes de genes, para citar alguns [Baek et al., 2012, Bassett e Bullmore, 2006, Easley e Kleinberg, 2012, Lago-Fernández et al., 2000, Latora e Marchiori, 2002].

A ocorrência de certas topologias particulares tem sido observada e caracterizada em diferentes campos de pesquisa. Alguns trabalhos ressaltam que diversas redes de fenômenos naturais não são aleatórias mas, ao contrário, seguem topologias específicas [Albert e Barabási, 2002, 
Amaral et al., 2000, Brockmann e Helbing, 2013, Easley e Kleinberg, 2012, Lago-Fernández et al., 2000, Vázquez et al., 2004].

\subsubsection{Caracterização e representação}

Uma vez que as redes complexas apresentam topologias distintas, é importante estabelecer maneiras de lidar com a informação sobre a topologia. Segundo [Costa et al., 2007a], dois aspectos são importantes: representação e caracterização. Uma rede pode ser caracterizada através de um vetor de características composto por medidas obtidas da rede, tais como do grau médio dos vértices, o caminho mínimo médio, betweeness, diâmetro, etc.

A Figura 2.6 mostra um exemplo onde um conjunto de $n$ características das redes $A$ e $B$ são extraídas em dois vetores de características $X_{a}$ e $X_{b}$, respectivamente. A comparação entre as redes pode então ser realizada no espaço de características, por exemplo, calculando a variação $\Delta_{x}$ entre os dois vetores.

\section{Rede A}
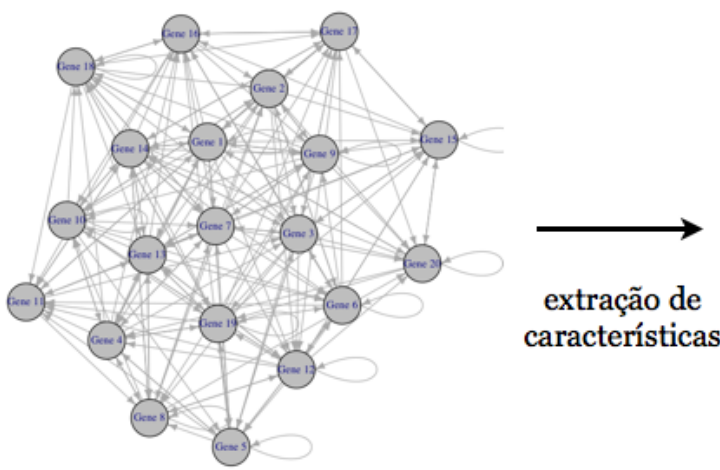

$$
\mathbf{x}_{\mathbf{a}}=\left[x_{a}^{1}, x_{a}^{2}, \ldots, x_{a}^{n}\right]
$$

características

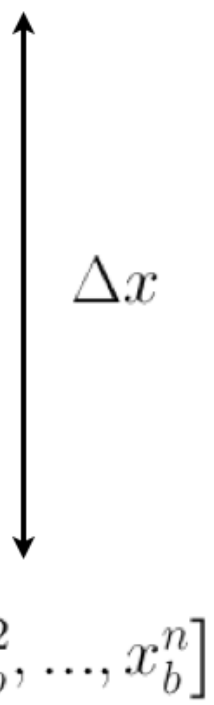

\section{Rede B}
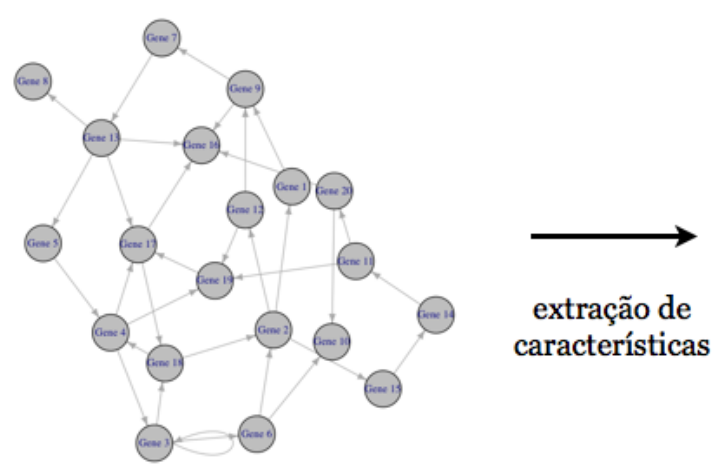

$$
\mathbf{x}_{\mathbf{b}}=\left[x_{b}^{1}, x_{b}^{2}, \ldots, x_{b}^{n}\right]
$$

Figura 2.6: Caracterização e Representação. Adaptado de [Costa et al., 2007a]. As redes $\boldsymbol{A}$ e $\boldsymbol{B}$ são representadas como grafos. Várias características (medidas) são extraídas de ambas as redes, por exemplo grau médio dos vértices, diâmetro, etc. O conjunto das $n$ características compõe um vetor de características para cada rede. A partir da caracterização é possível comparar as redes complexas no espaço de características.

Assim, o vetor de características pode ser utilizado para classificar e identificar as topologias das redes. Um conjunto de vetores de características de cada modificação topológica de uma rede pode 
ser usado para estudar a trajetória das medidas que caracterizam a rede. Por outro lado, o caminho inverso é normalmente impossível, isto é, a partir do vetor de características reconstruir a rede que o gerou. No entanto, quando a rede pode ser recuperada, diz-se que o mapeamento fornece uma representação. Exemplos de representação são a lista de arestas e a matriz de adjacência [Costa et al., 2007b, Pavlopoulos et al., 2011]. Em geral uma rede inferida é avaliada tomando-se em conta sua representação, comparando-se uma rede gabarito com a rede inferida. Uma das contribuições de um dos trabalhos apresentados nesta tese é o uso de um vetor de características para avaliar a inferência de redes. O estudo de redes complexas pode ocorrer em dois cenários principais: No primeiro, a topologia é determinada por construção através de um modelo gerador, e portanto, tanto a rede como suas propriedades podem ser claramente conhecidas a priori. Na segundo, o modelo gerador (se existir) é desconhecido e apenas o grafo (representação) pode ser observado. Frequentemente, tanto as regras de construção bem como a rede completa são desconhecidas. Tal é o exemplo das redes gênicas para as quais não se sabe se há alguma "lei" que determine a construção topológica das interações entre genes. Também, as redes biológicas são conhecidas apenas parcialmente.

Podem haver exceções quando se trata de redes artificiais como redes neuronais artificiais, redes de metrô, redes de distribuição de energia, redes de computadores, etc. para as quais alguns padrões já foram identificados em alguns trabalhos.

No tocante a sistemas vivos a classe topológica é desconhecida. No entanto, há trabalhos que sugerem que redes biológicas devam conservar propriedades topológicas [Jeong et al., 2000]. Alguns trabalhos sugerem modelos topológicos para redes biológicas como scale free [Albert e Barabási, 2002]. Segundo [Ma et al., 2004] uma estrutura hierárquica foi observada em Escherichia coli.

\subsubsection{Redes Small-World}

\section{Redes Small World}

Em especial, a topologia Small World (SW) [Milgram, 1967, Strogatz, 2001] tem sido observada em várias áreas e parece ser um fenômeno comum tanto em eventos físicos, redes sociais e redes biológicas. O primeiro artigo que investigou a existência de redes SW foi [Milgram, 1967] num trabalho sobre redes sociais. Alguns exemplos citados na literatura como tendo característica SW são redes de eventos sísmicos [Baek et al., 2012], rede de estações de metrô e estações de distribuição de energia[Latora e Marchiori, 2002], redes sociais [Milgram, 1967, Newman e Watts, 1999], redes da dinâmica de valores no mercado financeiro [Zhao et al., 2013], redes de propagação de epidemias [Moore e Newman, 2000], redes neurais [Bassett e Bullmore, 2006, Lago-Fernández et al., 2000].

Um modelo gerador conhecido de SW são as redes de Watts e Strogatz [Strogatz, 2001, Watts e Strogatz, 1998]. Este modelo tem duas propriedades especiais: o caminho mínimo médio é pequeno e o coeficiente de clustering é alto. Estas características SW foi observada em redes biológicas como por exemplo rede de interação proteína-proteína (PPI) [Assenov et al., 2008]. Também, segundo [Ravasz et al., 2002] num estudo de redes de 43 organismos, estes apresentaram redes com coeficiente de clustering alto.

Considerando-se que a inferência de redes de genes é também um problema inverso, onde mais do que uma rede podem produzir a mesma dinâmica. [Dougherty, 2007, Dougherty e Bittner, 2010], o uso da topologia poderia ajudar os algoritmos de busca, evitando estruturas biológicas improváveis. Um algoritmo onde a topologia scale-free [Albert e Barabási, 2002] foi utilizada para guiar o 
processo de busca, alcançou uma melhor precisão na inferência [Lopes et al., 2014a].

\subsection{Integração de dados}

Diante da limitação apresentada nos dados de expressão gênica e da maldição da dimensionalidade, outros tipos de informação biológica além dos dados de expressão vem sendo utilizadas a fim de reduzir o erro de estimação na descoberta dos relacionamentos entre os genes [Baitaluk et al., 2010, Hecker et al., 2009].

Algumas iniciativas foram propostas na literatura com o objetivo de integrar informações biológicas em métodos de inferência. Neste sentido, uma abordagem consiste em usar informações biológicas pontualmente, em geral disponíveis em bancos de dados públicos como Gene Ontology [Harris et al., 2004], GenBank [Benson et al., 2008], KEGG [Kanehisa, 2000], entre outros, no desenvolvimento de métodos de clustering, resultando em agrupamentos mais significativos do ponto de vista biológico [Cui et al., 2010, De Haan et al., 2010, Macintyre et al., 2010]. Mais especificamente, existem alguns métodos que buscam o uso de dados biológicos em métodos de inferência dos relacionamentos entre os genes, i.e., inferir GNs [Ernst et al., 2008, Seok et al., 2010, Werhli e Husmeier, 2008]. A melhoria proporcionada na inferência de GNs pela inclusão de informações biológicas motivou o desenvolvimento de vários outros métodos presentes na literatura [Baumbach et al., 2009, Hecker et al., 2009, Kaleta et al., 2010, Karlebach e Shamir, 2008, Marbach et al., 2012]. A integração entre dados de expressão, informações biológicas e modelos computacionais é um passo importante para a descoberta e caracterização de conhecimentos biológicos, mesmo que a sua aplicação seja limitada ao conhecimento biológico a priori de cada gene ou entidade biológica envolvida.

No entanto, uma questão ainda em aberto é entender como as informações biológicas contribuem para a descoberta dos relacionamentos entre os genes e ainda qual a contribuição individual e/ou combinada de cada informação utilizada no processo de inferência de GNs. Este trabalho aborda esse contexto e apresenta algumas contribuições. Outro objetivo deste trabalho é tornar o uso das informações biológicas conhecidas de forma menos restritiva. É proposto identificar e aplicar classes de informações no processo de inferência, i.e., o uso de informações locais ou globais a respeito de um organismo e não só a informação de um único gene de forma isolada. Um exemplo, é utilizar a estrutura de rede (topologia) como informação prévia no processo de inferência. A integração de múltiplos tipos de dados associados com propriedades locais e globais dos organismos, como suas características topológicas de conectividade entre os genes, pode ser decisivo para a efetiva predição de GRNs e suas funções em face das limitações conhecidas [Aittokallio e Schwikowski, 2006, Lopes et al., 2014a, Troyanskaya, 2005, Vidal, 2005].

De forma complementar são referenciados alguns dos trabalhos e respectivos dados biológicos adotados na inferência de GNs:

1. Uso de dados sobre as interações proteína-proteína [Ito et al., 2001, LaCount et al., 2005, Rual et al., 2005];

2. Uso de dados sobre as interações proteína-DNA [Johnson et al., 2007];

3. Uso de dados de função e ontologia disponíveis no KEGG [Kanehisa, 2000] e no Gene Ontology [Harris et al., 2004]; 
4. Uso da associação de função através de perfil filogenético [Pellegrini, 1999];

5. Uso de dados sobre as interações de proteínas via sequência genômica: Rosetta Stone Fusion Protein [Marcotte, 1999, Veitia, 2002].

\subsubsection{Escore Biológico}

O uso de dado biológico foi utilizado recentemente [Ray et al., 2009] com o objetivo de definir funções para genes. O trabalho definiu uma função, chamada pelo autor de Biological Score (BS), na qual um peso é definido para cada tipo de dado biológico. A função é definida da seguinte forma:

$$
B S_{x, y}=\frac{w_{1} \times D_{x, y}^{1}+w_{2} \times D_{x, y}^{2}+\cdots+w_{k} \times D_{x, y}^{k}}{\sum_{i=1}^{k} w_{i}},
$$

onde $D_{x, y}^{1}, \ldots, D_{x, y}^{k}$ são diferentes fontes de informação sobre a relação entre $x$ and $y$. Os valores $w_{i} \geq 0, i=1 \ldots k$ são os respectivos pesos de cada conjunto de dados.

No trabalho, diferentes informações biológicas foram usadas para aumentar a precisão na predição da função de genes. Cada conjunto de dados compreende as relações entre pares de genes e cada par tem associado a ele uma medida de similaridade. O Gene Ontology foi usado como gold standard para calcular a precisão. Os valores foram combinados no BS. Os pares de genes foram agrupados de acordo com o valor do BS, e foi usado um algoritmo de agrupamento KNN (k-nearest neighbors algorithm) [Theodoridis e Koutroumbas, 2008]. A função do gene foi associada de acordo com o grupo.

Apesar de várias fontes de dados serem usadas, o trabalho não trata de inferência de redes mas de associação de função aos genes. Um ponto que merece destaque é que o autor considera o GO como gold standard. Isto significa, embora não explicitado pelo autor, que o fundamento conceitual daquele trabalho consiste no pressuposto de que se dois genes estão relacionados em algum conjunto de dados biológicos, eles possivelmente deveriam compartilhar um termo GO comum, isto é, ter função similar, participar do mesmo processo biológico, etc. Assim, os pesos no Biological Score indicam quanto cada informação contribui para recuperar relação entre genes com GO em comum. No entanto, não fica claro como cada informação contribui para recuperar uma relação do mesmo tipo da informação fornecida.

$\mathrm{Na}$ inferência de redes gênicas com dados de expressão, uma aresta na rede inferida indica que $a$ expressão dos dois genes ligados pela aresta está relacionada. Para avaliar se a aresta inferida está correta utiliza-se um gold standard, uma rede previamente conhecida para a qual assume-se estar correta. O que é uma aresta correta? A definição depende do significado que se atribui a aresta. Por exemplo, se o modelo de inferência pressupõe a regulação transcricional, uma aresta deve indicar que a proteína codificada pelo gene preditor regula a expressão do gene alvo.

No entanto, outro tipo de relacionamento entre genes pode ser usado para avaliar a predição com relação a outros aspectos, como por exemplo, como fez [Ray et al., 2009] ao usar o GO como gold standard. A semântica do uso do GO naquele trabalho é: se dois genes compartilham um termo GO, significa que possuem um relacionamento biológico e portanto, a expressão de ambos deve estar relacionada, portanto a aresta está correta. Em outras palavras, a relação entre a expressão é explicada por outras razões biológicas além da regulação direta. 
O trabalho de Ray [Ray et al., 2009] elucida o relacionamento entre expressão e outros tipos de dados, no entanto, o trabalho não explorou como cada informação contribui para a inferência de relações do mesmo tipo da informação fornecida. Por exemplo, como a informação de interação proteína-proteína combinada a dados de expressão contribui para encontrar relações proteínaproteína?

\subsubsection{Independência entre informações biológicas}

Um outro trabalho [Lu et al., 2005] avaliou o limite de integração de dados para prever relações proteína-proteína. Usando um classificador Bayesiano, a relação entre o número de características (informação biológica) e a melhora na predição foram avaliados. O trabalho destacou 4 tipos de informações importantes: (a) similaridade funcional baseado em MIPS, (b) similaridade funcional com base em GO, (c) coessenciality e (d) correlação entre dados de expressão. Segundo o autor, a ausência de dependência estatística entre as informações disponíveis foi uma descoberta importante.

Embora o aumento do desempenho na predição de interações proteína-proteína seja importante, alguns outros aspectos podem ser destacados com relação ao trabalho: (a) A previsão não ocorreu no contexto da inferência de redes de genes, (b) a contribuição de cada informação não é clara, (c) a contribuição da informação proteína-proteína como informação prévia não foi avaliada.

\subsubsection{Dados de expressão e medidas de correlação}

Outra questão importante é que diversas abordagens de integração de dados são baseados na medida de correlação entre a expressão de pares de genes como em [Ray et al., 2009]. No entanto, alguns autores afirmam que, ao contrário dos organismos procariotos onde a correlação da expressão de pares de genes tem relação com a interação de suas proteínas correspondentes, em organismos eucariotos não há esta relação direta [Bhardwaj et al., 2005].Em outro trabalho o autor afirma que em Sacharomices cerevisiae and bacteriophage Tr7 a co-expressão e interações proteína-proteína podem estar relacionadas porém, destaca que auto-regulação não pode ser testada com correlação. Há ainda outros trabalhos como [Hecker et al., 2009], [Baitaluk et al., 2010] e [Kanehisa et al., 2010] em que a integração de dados contribui para reduzir o erro de estimação. Algumas das questões abertas com relação a integração de dados são: (a) quanto cada tipo informação contribui quantitativamente na inferência da rede quando combinada com dados de expressão? (b) a contribuição é proporcional ao peso da informação ? (c) como avaliar a rede inferida com relação a diferentes tipos de informação? Por exemplo: quantas das relações inferidas com dados de expressão mais alguma informação, correspondem a interações proteína-proteína? (d) é possível agrupar os diferentes tipos de dados em categorias ou classes?

\subsubsection{Heterogeneidade dos dados}

Um aspecto importante no uso de informação biológica diz respeito à heterogeneidade dos dados. Por exemplo, as redes de proteína-proteína obtidas a partir de Yeast Two Hybrid (Y2H) [LaCount et al., 2005], correspondem a verificação de interação física entre proteínas. Os dados Rosetta Stone Fusion Proteins correspondem a interações físicas de proteínas preditas indiretamente por meio de comparação de sequências de DNA e de Aminoácidos. Por outro lado, dados de via metabólica podem informar se elementos estão presentes na mesma via, não necessariamente im- 
plicando em uma interação física entre eles. Ainda, a informação de Ontologia de Genes como a localização celular é um dado de tipo qualitativo que pode indicar se dois genes atuam na mesma localização. Também, anotação da função pode informar se dois genes tem funções relacionadas. Se adotada a hierarquia do Gene Ontology, a informação pode indicar uma relação hierárquica entre os processos biológicos. 


\section{Capítulo 3}

\section{Materiais e Métodos}

\subsection{SFFS-BS}

Esta seção apresenta o Algoritmo de inferência SFFS-BS, a construção do conjunto de dados para inferência e validação e a metodologia utilizada para validar os resultados dos experimentos.

\subsubsection{Algoritmo de inferência}

O algoritmo SFFS-BS deste trabalho tem como base o Escore Biológico apresentado na Seção 2.8.1 e a Entropia Condicional Média apresentada na Seção 2.6.3. Para cada gene alvo é necessário encontrar o conjunto de no máximo $k_{\max }$ genes preditores dentre todos os $n$ genes da rede. Fazer uma busca exaustiva, numa combinação de $n, k$ a $k$, com $k$ variando de 1 a $k_{\max }$ é impraticável. Por isto, utiliza-se o algoritmo de seleção de características SFFS [Pudil et al., 1994, Somol et al., 1999] para realizar a busca. Abaixo serão apresentados o algoritmo com seu pseudocódigo e a função critério utilizada.

\section{Função critério}

A fim de recuperar as redes de genes a partir de perfis de expressão, foi aplicada a abordagem descrita em [Lopes et al., 2008c], baseada num algoritmo de seleção características. O método de seleção de características é composto por dois elementos principais: um algoritmo de busca e uma função critério. A função critério é utilizada para avaliar o poder preditivo de um conjunto de características. O algoritmo de busca é utilizado para percorrer o espaço de busca e encontrar o conjunto de características que minimiza o valor da função critério.

Assim, definimos uma função critério que utiliza o valor da Entropia Condicional Média dos dados de expressão e a informação biológica (PPI):

$$
B S_{Y, X}=D_{Y, X}^{E} \times w_{1}+D_{Y, X}^{P} \times w_{2},
$$

onde, dado um gene fixo $Y$ como alvo, o objetivo é determinar o subconjunto de genes $\mathbf{X}$ que faça a melhor predição do gene alvo $Y$ e seja coerente com a anotação PPI. Para isto a função critério leva em conta o valor de $D_{Y, X}^{E}$ e de $D_{Y, X}^{P}$ onde $D_{Y, X}^{E}$ é o valor da MCE com penalização obtido a partir do dado de expressão [Lopes et al., 2008c] e $D_{Y, X}^{P}$ é a informação obtida a partir do dado de PPI, onde $D_{Y, X}^{P}=1$ se existe uma interação entre $X$ e $Y$ na rede PPI, e igual a 0 , caso 
contrário. Neste trabalho, os coeficientes $w_{1}$ e $w_{2}$ são os pesos de cada tipo de dado, sendo números reais positivos de tal forma que $\sum w_{i}=1$.

\section{Algoritmo SFFS-BS}

A inferência da rede é realizada executando-se o Algoritmo 1 a seguir, para cada gene alvo. A rede inferida é composta pelo conjunto de todos os genes alvos e seus respectivos preditores.

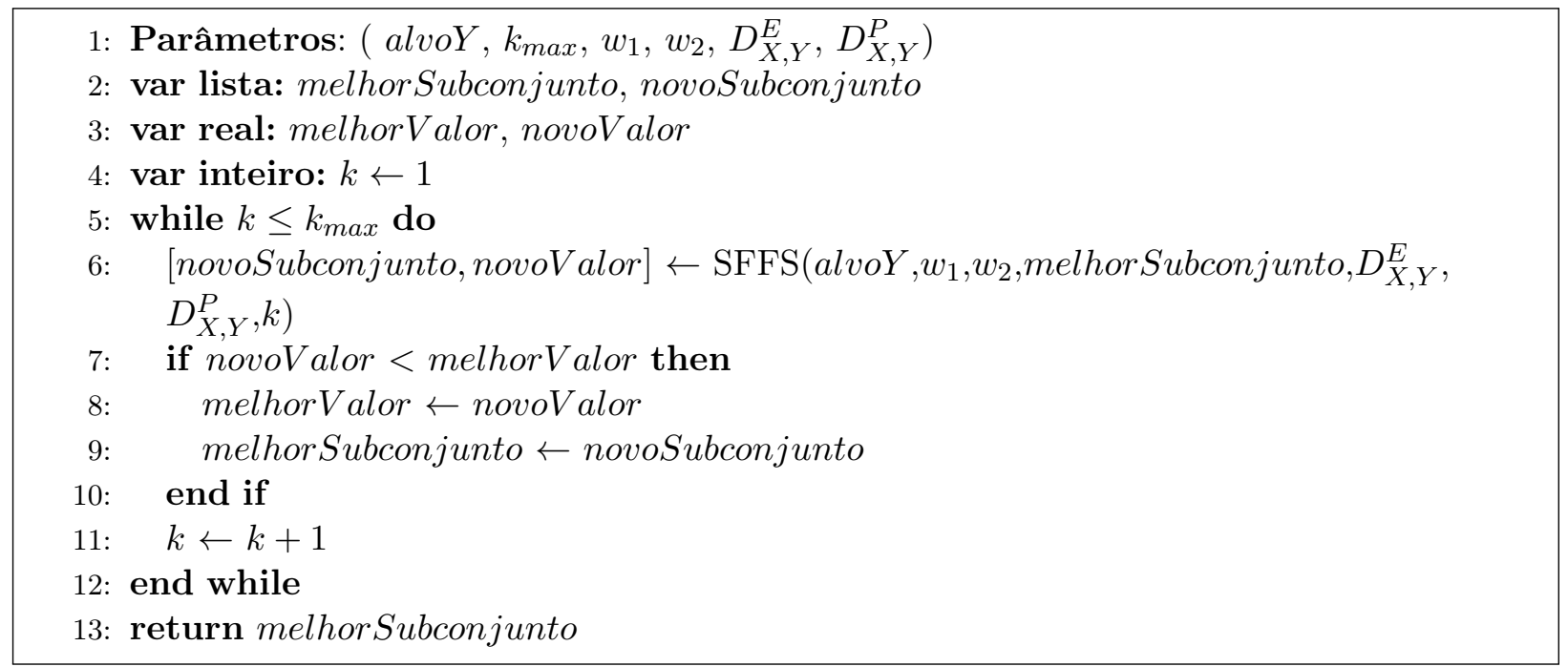

Algorithm 1: Algoritmo SFFS-BS: Faz a seleção de características (genes preditores) com base na função critério composta pela Entropia Condicional Média dos dados de expressão dos genes preditores e genes alvo e na informação biológica.

Inicialmente, o algoritmo recebe os parâmetros, onde alvoY é o gene alvo para o qual o algoritmo buscará por genes preditores tomando como base os dados de expressão e a fonte de informação biológica. O parâmetro $k_{\max }$ representa a cardinalidade máxima do subconjunto de preditores. Como há uma penalização de dados não observados, a função critério tende a favorecer conjuntos de preditores de menor cardinalidade. No entanto, esta limitação é importante por causa do tempo de execução, uma vez que impede que o algoritmo teste subconjunto de cardinalidade maiores que $k_{\text {max }}$. Os parâmetros $w_{1}$ e $w_{2}$ são, respectivamente, os pesos dados ao dado de expressão gênica $\left(D_{X, Y}^{E}\right)$ e ao dado de PPI $\left(D_{X, Y}^{P}\right)$.

A fim de evitar a avaliação de todas combinações possíveis de preditores, o que é impraticável, utiliza-se o algoritmo de busca SFFS [Pudil et al., 1994]. O SFFS é empregado para encontrar o melhor subconjunto (novoSubconjunto) de preditores para o gene alvo, para a cardinalidade $k$. A função critério adotada para avaliar a solução é o Escore Biológico, definido na Seção 2.8.1. Assim, a variável novoValor é o valor do Escore Biológico do subconjunto de preditores (novoSubconjunto). O algoritmo seleciona novoValor e novoSubconjunto como solução se o valor de novoValor for melhor que o valor corrente de melhorValor.

O laço while realiza a execução do SFFS para cardinalidade $k=1, \ldots, k_{\text {max }}$, para encontrar o melhor subconjunto de preditores em cada cardinalidade $k$ e armazena a solução global nas variáveis melhorValor e melhorSubconjunto. A condição de parada do algoritmo é o limite $k_{\max }$.

A contribuição de cada informação biológica foi avaliada com base nos parâmetros tal como definido na Seção 3.1.8. 
A seguir será apresentada a construção do conjunto de dados para inferência e validação, bem como cada tipo de dado utilizado na montagem do dataset.

\subsubsection{Dados de expressão}

O Malaria expression dataset fora publicado pela primeira vez por [Bozdech et al., 2003]; nesta tese foram utilizadas as amostras pré-processadas do USP dataset publicado em [Barrera et al., 2004]. O conjunto de dados inclui amostras de 6.532 genes que foram filtrados através de um controle de qualidade (excluiu genes com menos de 25 amostras temporais) e o sinal foi normalizado e quantizado em três níveis de expressão $\{-1,0,+1\}$ : sub-expresso, transcrição basal, super-expresso, com relação à referência.

Como proposto por [Barrera et al., 2004], as séries temporais de expressão de cada gene $g(t), t=$ $1,2, \ldots, n$, são normalizadas:

$$
\eta[g(t)]=\frac{g(t)-E[g(t)]}{\sigma[g(t)]}
$$

onde $\sigma[g(t)]$ é o desvio padrão de $g(t)$ e $E[g(t)]$ é o valor esperado de $g(t)$.

Após a transformação normal, o sinal $\alpha$ de cada gene $g$ em cada instante $t \geq 0$ é quantificado por meio de um mapeamento como segue:

$$
g(t)=\left\{\begin{array}{rc}
+1 & \alpha \geq h \\
0 & l \leq \alpha \leq h \\
-1 & \alpha \leq l
\end{array}\right.
$$

Onde $l$ e $h$ são obtidos pela divisão do espaço de valores de $\alpha$ em 3 intervalos. Neste trabalho, foram selecionados apenas subconjuntos de genes presentes tanto na rede de [LaCount et al., 2005] e nos dados de expressão. Os dados de expressão resultantes compreendem 1.441 genes e 48 amostras temporais. Como resultado, construiu-se uma rede PPI com 1.930 arestas.

\subsubsection{Dado de rede de interação proteína-proteína - PPI}

Uma questão importante na proposta de novos algoritmos de inferência de GNs é a avaliação da rede recuperada a partir dos dados. Uma forma de fazer a avaliação é utilizando dados simulados no qual uma rede é gerada assim como os dados de expressão correspondentes. Quando a avaliação envolve dados reais é necessário utilizar uma rede gabarito (gold standard biológica previamente conhecida). A rede biológica geralmente é parcial, isto é, as relações conhecidas são apenas parte do conjunto total existente na natureza.

No entanto, na revisão bibliográfica, foi possível constatar que não há um consenso sobre como um conjunto de dados gold standard deve ser construído. Em geral, tratando-se de inferência a partir de dados de expressão, uma rede gabarito comumente contém informação da rede de regulação transcricional, na qual o vértice de origem corresponde a um Fator de Transcrição e o vértice de destino corresponde a um gene alvo. No entanto, para avaliar as redes inferidas, alguns trabalhos utilizam de redes de interação proteína-proteína, uma vez que uma explicação possível para relação entre os níveis de expressão é que as proteínas correspondentes interagem e podem ser transcritas simultaneamente. Em outros trabalhos, relações de genes que partilham os mesmos termos de 
ontologia são utilizados para avaliar o resultado. Neste sentido, os diferentes gold standard servem para avaliar a coerência semântica das relações inferidas.

Assim, uma abordagem comum para avaliar as ligações previstas entre genes é a de questionar se cada relação inferida é suportada por algum dado de anotação. A confiança na aresta inferida pode ser reforçada se:

- participa da mesma via metabólica

- compartilha a localização celular

- possui a mesma função.

Alguns destes dados fornecem informação de tipo qualitativa que não deixa claro se os dois genes (ou os seus produtos correspondentes) interagem fisicamente, nem podem confirmar uma relação TF-DNA. No entanto, os dados de anotação permitem contagem de pares que são biologicamente relacionados. Outros dados fornecem informação sobre a interação física de proteínas. Assim, se as proteínas correspondentes ao par de genes de uma aresta, interagem fisicamente, há indicação de que a relação inferida entre as expressões gênicas está correta.

Neste sentido, se o dado fornece realmente alguma informação que corrobora com o dado de expressão, seria interessante investigar como ele contribuiria para prever o próprio tipo de informação que fornece.

Neste projeto utilizou-se dados de PPI de Plasmodium falciparum identificada por [LaCount et al., 2005]. Os dados correspondem a experimento de duplo híbrido (Y2H). A fim de obter uma rede confiável, várias interações obtidas a partir de 32.448 experimentos de Y2H foram eliminadas em uma análise posterior. Fragmentos de proteína com um número muito alto de interações foram eliminados para evitar "interações promíscuas"[LaCount et al., 2005]. A rede resultante tem topologia scale-free e é altamente interconectada, compreendendo 1.267 proteínas (nós) e 2.823 interações.

\subsubsection{Dado Rosetta Stone Fusion Proteins}

Os dados Rosetta Stone Fusion Proteins correspondem a predição de interação proteína-proteína, obtidos indiretamente a partir de sequências genômicas. Em certo sentido, a informação deste tipo é similar a informação Y2H, uma vez que descreve possíveis interações físicas diretas.

O termo "Rosetta Stone" foi proposto no artigo [Marcotte, 1999]. O dado tem como base a observação de que algumas proteínas que participam de uma interação proteína-proteína em um dado organismo podem formar uma única cadeia proteica em um outro organismo evolutivamente próximo. Dito de outro modo, em alguns casos observa-se que sequências de duas proteínas que interagem fisicamente em um organismo, formam uma única proteína em um organismo próximo. Assim, segundo o autor, é possível inferir a interação a partir de dados de sequência. É neste sentido que o termo "Rosetta Stone" é usado, uma vez que a associação na sequência é usada para "decifrar" uma interação proteína-proteína.

Neste projeto, usou-se o conjunto de dados publicado por [Date e Stoeckert, 2006]. Segundo o artigo, o dado foi obtido utilizando-se sequências de Plasmodium falciparum mais outros 164 genomas. Os dados excluem interações encontradas apenas no Plasmodium como forma de selecionar interações mais prováveis, isto é, que ocorrem também nos demais organismos. A rede resultante é composta por 993 proteínas, com 5.175 arestas. 
Para este projeto, foram selecionadas as proteínas encontradas tanto no dataset do dado biológico quanto nos dados de expressão. A rede resultante da interseção dos conjuntos de dados é composta por 702 genes e 2.146 arestas.

\subsubsection{Dado de KEGG}

KEGG (Kyoto Encyclopedia of Genes and Genomes) [Kanehisa, 2000] é uma base de dados de vias metabólicas na qual são descritas diversas interações moleculares. Através do KEGG pode-se obter pelo menos dois tipos de informação: (a) se o produto de um par de genes interage diretamente em uma via metabólica e (b) se o produto de um par de genes interage indiretamente, participando da mesma via metabólica, porém sem uma interação física direta.

No trabalho, utilizou-se o gold standard construído e publicado por [Hu et al., 2009]. A rede contém 492 genes e 11.046 arestas. Quando um par de genes está associado no KEGG, uma aresta foi adicionada a eles. Um conjunto de dados para validação também foi construído a partir da interseção deste dado com os dados de expressão, resultando em uma rede com 393 genes e 8.750 arestas.

\subsubsection{Dado de KEGG mais GO}

Este conjunto de dados foi construído a partir de duas fontes de informação biológica. A primeira, o GO que é uma fonte de informação sobre três aspectos: (a) componente celular (a localização física na célula ou o ambiente extracelular onde o gene atua), (b) função molecular e (c) processo biológico.

Neste trabalho utilizou-se um conjunto de dados pre-processado e publicado por [Date e Stoeckert, 2006]. A rede contém dados de informação combinada de vias do KEGG e GO de Plasmodium falciparum. Em relação ao GO, uma profundidade mínima igual a 5 foi utilizada como limiar.

Quanto a profundidade do GO é importante ressaltar uma questão importante. Uma vez que um par de genes seja associado por algum método (por exemplo correlação dos dados de expressão), uma forma de avaliar a relação é perguntar se o par compartilha o mesmo termo GO. No entanto, embora esta informação possa ser tratada como de tipo nominal, o GO possui uma estrutura hierárquica. Como já mencionado, o GO é um DAG (Grafo Acíclico Dirigido). Portanto, é importante conhecer a que nivel ou profundidade os genes compartilham a mesma anotação. Por exemplo: suponha que o par de genes está associado ao termo GO cellular metabolism. Esta informação é suficiente para aceitar a relação como correta? Há diversos genes envolvidos em cellular metabolism e muitos deles não estão relacionados um com o outro uma vez que esta informação é muito genérica. Desta forma, a informação do GO pode gerar ruído ao invés de contribuir na avaliação.

Ainda seguindo este exemplo, considere um outro cenário. Suponha que o par de genes está associado ao termo acetyl-CoA biosynthesis from acetate. Também é um termo GO, porém é mais específico que cellular metabolism. Portanto, este tipo de informação (tal como descrita no conjunto utilizado) não deixa claro se dois genes ligados por uma aresta interagem diretamente. No entanto, a informação ainda pode fornecer uma idéia da credibilidade da aresta inferida.

O conjunto de dados utilizado contém 412 proteínas e 10.267 arestas. Após a interseção com os dados de expressão, o dataset de validação contém 344 proteínas e 7.204 arestas. O resumo dos conjuntos de dados originais é exibido na Tabela 3.1 
Tabela 3.1: Resumo das fontes de dados utilizadas para avaliação da inferência

\begin{tabular}{cccc}
\hline Gold Standard & Genes & Arestas & Publicação \\
\hline Protein-Protein & 985 & 1958 & LaCount et al, 2005 \\
Rosetta Stone & 702 & 2146 & Date et al, 2006 \\
KEGG & 393 & 8750 & Bozdech et al, 2003 \\
KEGG+GO & 344 & 7204 & Date et al, 2006 \\
\hline
\end{tabular}

\subsubsection{Interseção entre os conjuntos de dados}

Com o objetivo de avaliar a combinação de dados de diferentes fontes, neste trabalho foram construídos quatro conjuntos de dados a partir da interseção dos conjuntos de dados originais (Tabela 3.2). Como se pode notar pelo tamanho das redes obtidas pela interseção dos dados, conseguir dados suficientes é comumente difícil. Uma das principais razões é que os experimentos que geram dados, são realizados com objetivos distintos. O uso dos dados para integração na inferência ainda não é comumente o objetivo principal de sua produção.

Tabela 3.2: Interseção dos conjuntos de dados

\begin{tabular}{cccc}
\hline IGS & Intersection & Genes & Arestas \\
\hline IGS1 & Rosetta $\cap$ KEGG+GO $\cap$ KEGG & 25 & 21 \\
IGS2 & Rosetta Stone $\cap$ KEGG & 31 & 45 \\
IGS3 & Rosetta Stone $\cap$ KEGG+GO & 36 & 28 \\
IGS4 & KEGG $\cap$ KEGG + GO & 314 & 6138 \\
\hline
\end{tabular}

\subsubsection{Metodologia de avaliação}

Para quantificar a similaridade entre a rede gold standard e as redes inferidas, foram adotados o PPV (Valor de Predição Positivo, do inglês Positive Predictive Value), também conhecido como precisão, e a Sensibilidade (ou recall). Segundo [Dougherty, 2007], estas medidas são amplamente utilizadas na avaliação de inferência de redes. Estas medidas baseiam-se numa matriz de confusão, conforme descrito na Tabela 3.3.

Tabela 3.3: Matriz de Confusão. TP = verdadeiro positivo (True Positive), $F N=$ falso negativo (False Negative), $F P=$ falso positivo (False Positive), $T N=$ verdadeiro negativo(True Negative).

\begin{tabular}{c|c|c} 
Aresta & Inferido & Não Inferido \\
\hline Presente & TP & FN \\
Ausente & FP & TN
\end{tabular}

As redes são representadas em termos de suas respectivas matrizes de adjacência $M$, de modo que cada aresta do no $i$ ao nó $j$ implica $M(i, j)=1$, com $M(i, j)=0$, caso contrário. As medidas consideradas neste projeto e nos demais projetos são:

$$
\begin{gathered}
\text { Similaridade }(A, B)=\sqrt{P P V \cdot \text { Sensibilidade }} \\
P P V=\frac{T P}{(T P+F P)}, \quad \text { Sensibilidade }=\frac{T P}{(T P+F N)} .
\end{gathered}
$$


Tendo como referência a rede gabarito $A$ e comparando-a com a rede inferida $B$, a medida de Similaridade $(A, B)$ é a média geométrica PPV e similaridade. Assim, a máxima similaridade possível é igual a 1.

\subsection{SFFS-SW}

O método proposto baseia-se no modelo de PGN, como apresentado na Seção 2.4.3 são estabelecidos dois novos axiomas:

i O modelo gerador da rede segue a topologia small-world tendo como características alto coeficiente de clustering e baixo caminho mínimo médio como descrito na Seção 2.7.2.

ii Assume-se que a rede small-world seja gerada com probabilidade de redirecionamento $p$ entre 0.001 e 0.1

Um dos problemas da inferência de redes gênicas é o espaço de busca. Mesmo limitando a quantidade de possíveis preditores $k_{\max }$ para cada gene alvo $n$, uma busca exaustiva teria que testar uma combinação de $n$ genes, tomados $k$ a $k$ para $k=1 \ldots k_{\max }$. Além disto, segundo [Dougherty, 2007, Dougherty e Bittner, 2010] a inferência de GNs a partir de dados de expressão é um problema inverso no qual mais de uma rede poderia gerar os mesmos dados observados. Por outro lado, uma rede biológica não deve ter uma topologia aleatória [Albert e Barabási, 2002, Brockmann e Helbing, 2013]. Assim, como forma de lidar com o imenso espaço de busca propusemos um algoritmo [Vicente e Lopes, 2014] que limita a busca a redes intencionalmente enviesadas para dadas características topológicas em particular. Como apresentado na Seção 2.7, alguns trabalhos sugerem que redes biológicas tenham topologia Small World (SW). Assim, neste trabalho desenvolveu-se um algoritmo que infere uma GN enviesada para a topologia SW.

Com o objetivo de avaliar o algoritmo de inferência optou-se pela geração de uma Rede Genica Artificial (AGN) [Lopes et al., 2008b, 2011]. O emprego de uma AGN na fase inicial de desenvolvimento de um algoritmo é importante porque permite a criação de um cenário controlado, isto é, tanto a topologia quanto os dados gerados pela rede são definidos a priori. Além disto, podese produzir um número ilimitado de redes, variando a quantidade de genes, os parâmetros que caracterizam a rede e o tamanho das séries temporais.

\subsubsection{Redes Small World de Watts e Strogatz}

Neste trabalho foi adotado o modelo gerador de redes SW proposto por Watts e Strogatz [Watts e Strogatz, 1998], que permite ajustar graus de aleatoriedade na geração da rede. A construção da rede com o modelo gerador de Watts e Strogatz é realizada da seguinte forma:

1. Defina $N$ como o número de vértices e $k$ como o grau médio

2. Inicie o grafo como uma malha, na qual cada vértice é conectado a $2 k$ vizinhos adjacentes

3. Percorra todos os vértices, redirecionando cada aresta com probabilidade $p$

Neste modelo, o parâmetro $p$ define o grau de aleatoriedade, variando da malha regular original $(p=0)$ até uma rede totalmente aleatória $(p=1)$. Duas medidas caracterizam esta rede: (a) um 
alto coeficiente de clustering e (b) um baixo valor de caminho mínimo médio para valores de $p$ entre 0.001 e 0.1 .

\subsubsection{Extração de características da GN}

Para extrair características da rede, calculamos o coeficiente de clustering de cada vértice $C_{v}$ da seguinte forma:

1. dado o vértice $v$, selecione seus $m$ vizinhos

2. conte o número de arestas $\eta_{v}$ entre os $m$ vizinhos de $v$, com exceção das arestas com $v$

3. calcule o número máximo de arestas em um grafo com $m$ vértices: $\eta_{m}=m(m-1) / 2$

4. calcule $C_{v}=\eta_{v} / \eta_{m}$

Então, o coeficiente de clustering global é calculado como:

$$
C=\frac{1}{N} \sum_{v \in V} C_{v}
$$

Outra característica calculada da rede é o caminho mínimo médio da rede $L$. Seja $L_{i j}$ o caminho minimo entre dois vértices $v_{i}$ e $v_{j}$, definido como o número de arestas no caminho mais curto entre $v_{i}$ e $v_{j}$ no grafo. Assim, calculamos $L$ como uma média de todos os $L_{i j}$ da rede. Seja $\lambda$ o número de caminhos na rede.

$$
L=\frac{1}{\lambda} \sum_{v_{i}, v_{j} \in V} L_{i j}
$$

Assim, uma proposta do método é avaliar os valores $C$ e $L$ durante a busca. Com relação a isto há um aspecto importante a ser considerado: o coeficiente de clustering $C \in[0,1]$ enquanto que $L \geq 1$, sem limite superior, uma vez que $N$ é um parâmetro da rede. Em uma rede de parâmetro $N$ conhecido, o caminho máximo teórico entre um par de vértices $\left(v_{i}, v_{j}\right)$ é $N-1$. Para a definição da função critério é interessante que os valores de $L$ e $C$ estejam normalizados dentro do mesmo intervalo de valores. Uma normalização do valor de $L$ poderia ser realizada utilizando-se o máximo teórico, no entretanto o valor de $L_{i j}$ em uma topologia SW será frequentemente muito menor que o máximo teórico $N-1$.Assim, neste método o valor $L$ calculado a partir de uma rede sendo inferida, é normalizado utilizando normalização min-max conforme a Equação 3.7 .

$$
\operatorname{Normalized}(L)=\frac{L-\min }{\max -\min }
$$

Onde, $\min =1$ e $\max$ é estimado, amostrando-se 1000 redes SW com os mesmos parâmetros $k, N$ e $p$, tomando-se o maior caminho mínimo médio.

\section{Função critério MCE-SW}

A função critério definida (MCE-SW) é composta de dois elementos: a MCE calculada a partir dos dados de expressão e medidas de caracterização da topologia SW. A função critério tem um parâmetro $w \in[0,1]$ que é o peso da topologia. 
Cada característica topológica ( $L$ e $C$ ) é ponderada por $w_{1}=\frac{w}{2}$ e o peso do dado de expressão é $w_{2}=1-w$. Assim, a função critério MCE-SW de duas variáveis $x$ e $y$ é calculada da seguinte forma:

$$
\begin{aligned}
\mathrm{MCE}-\mathrm{SW}_{y, x} & =w_{2} \times M C E_{x, y}+w_{1} \times L-w_{1} \times C \\
& =w_{2} \times M C E_{x, y}+w_{1} \times(L-C)
\end{aligned}
$$

Onde $C \in[0,1]$ e $L \in[0,1]$. Como $(L-C) \in[-1,1]$, o valor é ajustado em $[0,1]$ para manter o valor do escore positivo.

$$
S W=\frac{(L-C)+1}{2}
$$

Assim, a função critério MCE-SW é :

$$
\operatorname{MCE}-\mathrm{SW}_{y, x}=w_{2} \times M C E_{x, y}+w_{1} \times S W
$$

\subsubsection{Algoritmo de seleção de características: SFFS-SW}

Tendo definido a função critério, nesta seção é apresentado o algoritmo de inferência de GNs a partir dos dados de expressão, o qual tem dois elementos principais. Um deles é a função critério em si, que é utilizada para avaliar uma solução local, isto é, os possíveis preditores para um único gene alvo por vez. Outro elemento é o mecanismo de busca, que é definido pelo algoritmo SFFS e que também realiza uma busca local, no sentido de que também a faz para um gene alvo por vez. Em outras palavras, a princípio o algoritmo de inferência recupera a rede global a partir de várias inferências locais. O algoritmo proposto aqui, leva em conta tanto as características locais como globais, isto é, ao mesmo tempo em que avalia um conjunto de preditores para um único gene alvo por vez, a função critério leva em conta como a alteração local particular afeta as características topológicas globais da rede. Em outras palavras, o valor da MCE-SW considera a entropia do conjunto de preditores e também como a escolha daquele conjunto de preditores em particular afeta a topologia da rede.

O algoritmo de inferência (Algoritmo 2) foi definido da seguinte forma:

A inferência é realizada em duas etapas: Na primeira etapa, a rede é inferida apenas a partir dos dados de expressão usando MCE como função critério. Isto garante uma topologia inicial. No segundo passo, cada vértice da rede é visitado na mesma ordem em que foi visitado na etapa 1. Para cada vértice a MCE-SW é utilizada como função critério para a busca com SFFS. Ao revisitar cada vértice e realizar a busca de seus preditores com MCE-SW, tanto o aspecto local quanto o aspecto global de seus preditores é considerado na busca.

Inicialmente recebe como parâmetros a lista de genes $G$, o número de genes $N$, os dados de expressão $D$, o número máximo de preditores $m f$ para cada gene alvo $Y$ e o peso da informação topológica $w$. Ao final da primeira estapa há uma rede inferida apenas com informação da expressão. A cada passo na etapa 2, o SFFS realiza a busca pelo melhor conjunto de preditores de $Y$, usando MCE-SW como função critério. Em cada passo do SFFS, as arestas do conjunto de preditores $X$ que 


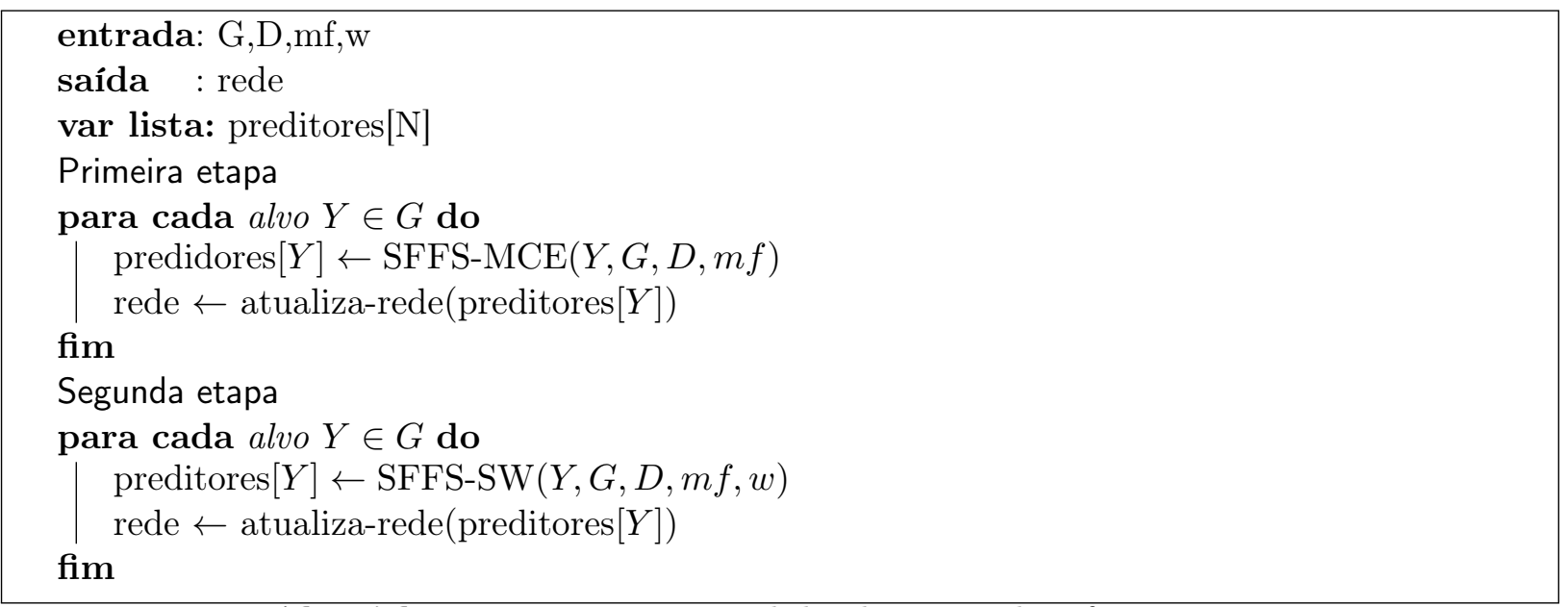

Algorithm 2: Função principal do algoritmo de inferência

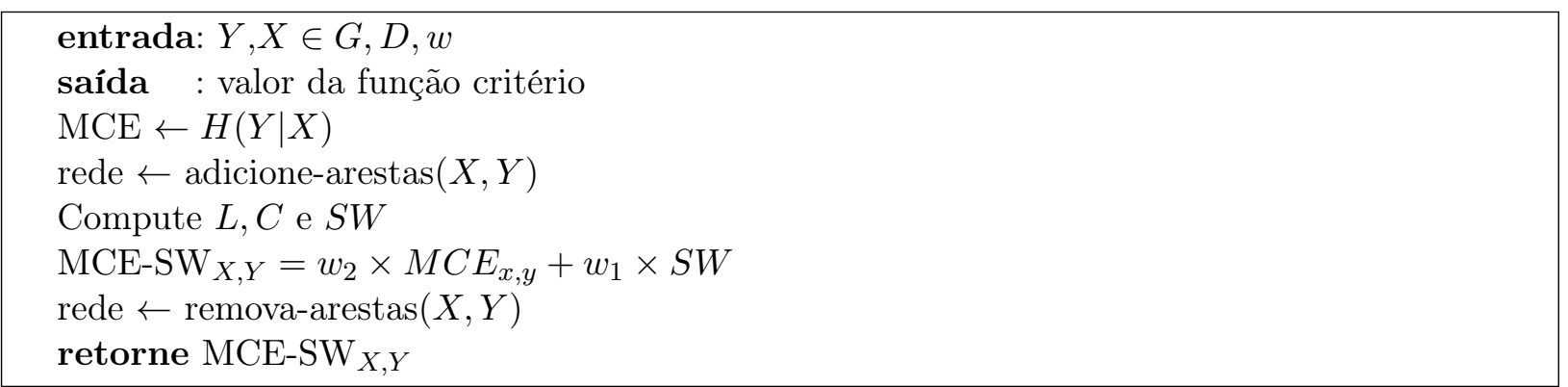

Algorithm 3: MCE-SW: computação da função critério

está sendo avaliado são adicionadas temporariamente ao grafo e as medidas topológicas $C$ e $L$ são calculadas, bem como a MCE-SW. Após calculada a MCE-SW, as arestas são novamente removidas do grafo. Ao final da busca pelo SFFS, quando é definido o melhor subconjunto de tamanho $k$, as arestas entre os preditores $X$ e o alvo $Y$ são definitivamente adicionadas ao grafo. Assim, como parte do algoritmo global SFFS-SW, um algoritmo SFFS modificado insere e remove arestas no grafo como apresentado no Algoritmo 3.

\subsubsection{Metodologia de avaliação}

Para avaliação do método utilizamos a rede gold standard gerada com o software AGN [Lopes et al., 2008b, 2011] e as mesmas medidas e cálculo de matriz de confusão apresentadas na Seção 3.1.8. Foram geradas com 100 vértices e grau médio variando de 1 a 4 . A probabilidade de redirecionamento de aresta foi definida como $p=0.01$ e o limiar da função critério igual a 0.3. Para cada configuração foram realizadas 10 execuções. Em cada execução foi gerada uma rede na etapa 1. Em seguida, na etapa 2, o algoritmo foi executado com os seguintes pesos da informação topológica: 0.2, 0.4, 0.6, 0.8 e 1.0. Para cada peso a rede da etapa 2 começa a ser inferida tendo como base a mesma rede da etapa 1. Além disto, também avaliamos a trajetória das medidas topológicas durante a inferência. 


\subsection{Integração de dados e inferência de redes em Arabidopsis tha- liana}

\subsubsection{Função critério}

A função critério definida neste trabalho é ligeiramente diferente daquela definida no trabalho com Plasmodium falciparum, descrito na Seção 3.1.1. A diferença é o formato do dado e como a informação é processada. No trabalho da Seção 3.1.1, o dado biológico é representado como uma rede e indica a presença ou ausência de relação entre os genes naquela fonte de dados. Nesta implementação a informação de cada gene consiste em um conjunto de valores (nominais). Por exemplo, para um dado gene há uma lista de termos sobre função, localização, etc. Estes termos foram indexados em rótulos. Cada um destes rótulos corresponde a uma característica do gene analisado. A parte da equação que avalia a informação biológica avalia a interseção do conjunto de valores dos genes avaliados.

A função mantém a mesma forma baseada no Escore Biológico

$$
F(Y, X)=w_{1} \times[H(Y \mid X)]+w_{2} \times[D(Y, X)],
$$

Onde, $D(Y, X)$ é igual a 1 se a interseção entre os conjuntos de características dos gene alvo $Y$ e preditores $X$ tiver tamanho maior ou igual a 1. Neste trabalho considerou-se apenas informações de tipo nominal. A função $D$ poderia ser adaptada para dados numéricos ordinais, por exemplo representando a distância entre dois termos GO com relação à profundidade do grafo GO.

Os parâmetros, $w_{1}$ e $w_{2}$ definem os pesos de cada informação, onde $w_{1} \in(0,1)$ e $w_{2}=1-w_{1}$.

\subsubsection{Rede gold standard}

Neste projeto construímos um gold standard a partir da rede regulatória de Arabidopsis thaliana. A rede gold standard é um grafo dirigido com interações físicas diretas conhecidas entre cada preditor (Fator de Transcrição) e seus genes alvo. A rede de Arabidopsis foi obtida do AGRIS: the Arabidopsis Gene Regulatory Information Server, an update [Yilmaz et al., 2011]. Nesta rede, cada interação foi verificada em pelo menos uma abordagem experimental. A rede contêm 8.154 genes, dos quais 67 são preditores e 8.131 são genes alvo. A rede tem 11.481 arestas no total. Alguns preditores também são alvo de outros TFs. Alguns preditores são representados com Complexos de $T F$. No AtRegNet, um Complexo de TF é definido como "mais de um regulador transcricional que é recrutado simultaneamente, e muitas vezes de forma sinérgica, ao DNA." (tradução de [Yilmaz et al., 2011]). Assim, na rede original eles são representados como um único vértice. Porém, devido a limitação da representação da rede pelo modelo de inferência, os vértices deste tipo foram convertidos em dois vértices distintos. Na rede, o número de casos deste tipo representa menos de $1 \%$ do total.

\subsubsection{Dados de expressão}

Os dados de expressão dos genes da rede AtRegNet foram obtidos do GEO [Barrett et al., 2013] e apenas amostras da plataforma GPL198 (Affymetrix Arabidopsis ATH1 Genome Array) foram usados. O chip contém 22.810 probe sets que foram mapeados em genes através de dados de anotação do TAIR [Lamesch et al., 2011], Gene Ontology [Harris et al., 2004] e TIGR [Childs et al., 2007]. 
Um script que utiliza os pacotes GEOquery e Biobase [Davis e Meltzer, 2007, Gentleman et al., 2004] do R Bioconductor [Gentleman et al., 2004, Huber et al., 2015] foi escrito para a obtenção dos dados no formato de arquivo SOFT. Os valores de expressão foram obtidos a partir dos arquivos SOFT e os dados foram preprocessados. As amostras com dados ausentes foram excluídas do conjunto de dados. Assim, o preprocessamento de um total de 180 arquivos resultou em uma tabela com 22.746 genes e 1.206 amostras de expressão.

\subsubsection{Informação biológica de Arabidopsis thaliana}

Foram obtidas características associadas a cada gene nos dados de expressão a partir da busca no TAIR, KEGG e NCBI [Edgar et al., 2002]. Para cada gene, o locus identifier correspondente no TAIR e o NCBI gene id foram obtidos. Estes termos foram utilizados para obter diversas características, das quais foram adotadas três delas: function, localization e pathway neste trabalho. $\mathrm{O}$ dataset de dado biológico contêm 23.593 genes e 15 características relacionadas a vários aspectos biológicos. Vale ressaltar que estes dados são diferentes daqueles utilizados no trabalho com Plasmodium falciparum. Cada característica neste conjunto de dados assume vários valores (de tipo nominal) enquanto que no trabalho com o Plasmodium a informação indicava a presença ou ausência de uma relação conhecida a priori entre cada par de genes.

\subsubsection{Avaliação do método}

O método foi avaliado com a variação dos pesos da informação biológica, calculando a matriz de confusão e calculando as medidas de avaliação conforme descrito na seção 3.1.8. A diferença nesta avaliação é a utilização da rede regulatória como gold standard e comparação da variação do threshold da MCE. 


\section{Capítulo 4}

\section{Resultados}

\subsection{SFFS-BS}

Esta seção apresenta os resultados experimentais dos dois primeiros trabalhos [Vicente et al., 2011] e [Vicente et al., 2012] descritos na Seção 3.1.

Uma das aplicações importantes de algoritmos de inferência de redes a partir de dados de expressão é na descoberta de novas interações. Em qualquer rede inferida a partir de dados de expressão, uma aresta entre dois genes indica que a expressão deles está relacionada. Considerar que a aresta corresponda a uma relação entre um regulador (TF) e um gene alvo no organismo real constitui apenas uma hipótese. Porém, é este mesmo o objetivo da inferência: levantar hipóteses que possam ser validadas posteriormente. Neste sentido, na avaliação de algoritmos de inferência, geralmente adota-se como gold standard uma rede regulatória, já que comumente o objetivo é avaliar a capacidade do algoritmo de prever relações regulatórias. No entanto, quando o algoritmo é aplicado para predizer novas interações, geralmente outros tipos de dado são utilizados para avaliar as predições (hipóteses), como redes PPI, dados de vias metabólicas, etc. É neste sentido que os dados de PPI, ontologia, etc. são utilizados como gold standard para a avaliação do ganho. Em outras palavras, o estudo avalia a relação entre as interações obtidas pelo dado de expressão e outras fontes de dado biológico.

Neste trabalho o mesmo método e parâmetros default foram mantidos fixos durante a análise comparativa entre a inferência realizada apenas com o dado de expressão e aquela que combina expressão e dado biológico de outro tipo.

Um aspecto importante desta metodologia é a escolha dos pesos atribuídos a expressão e dado biológico. Para avaliar o ganho relativo do uso do dado biológico, variou-se o peso da seguinte forma: $w_{1}=1-w_{2}$ e $w_{2}=0,0.1,0.2, \ldots, 1$.

A seguir são destacados os resultados com os diferentes tipos de dados.

\subsubsection{Dados de PPI}

A Figura 4.1 apresenta o ganho relativo em termos de similaridade, precisão (PPV) e sensibilidade entre a rede inferida e a rede PPI. Nesta avaliação a própria rede PPI foi utilizada como gabarito pois o objetivo do estudo é avaliar a relação entre o dado de expressão e o tipo de dado biológico utilizado. Sobre outra perspectiva, avalia o potencial de inferir rede de relacionamento entre expressões gênicas suportadas por interação proteína-proteína. As medidas de avaliação foram 
descritas na Seção 3.1.8.

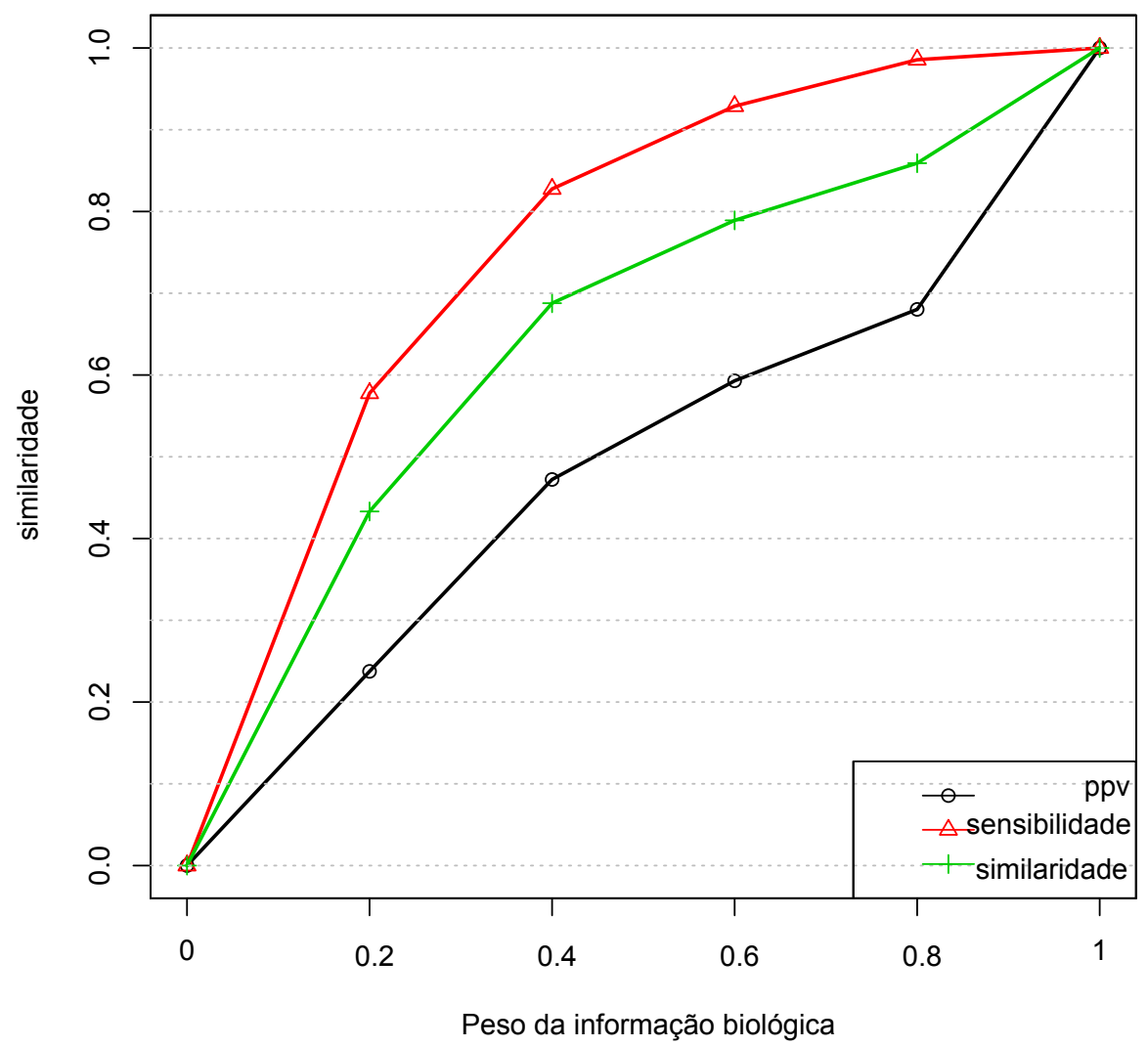

Figura 4.1: Similaridade, Precisão e Sensibilidade obtida com a variação do peso entre a informação biológica e o dado de expressão. Quando o peso é igual a 0 apenas o dado de expressão é considerado. Quando o peso é igual a 1 apenas o dado de PPI é considerado. O aumento do peso para o dado biológico de PPI produz aumento da similaridade e o resultado também mostra que o ganho não é linear e para Sensibilidade é melhor que um ganho linear.

Na Figura 4.1, o eixo $x$ informa o peso atribuído ao dado biológico (presença de uma interação proteína-proteína na rede PPI) e o eixo $y$ o ganho relativo. O ponto $(0,0)$ corresponde a inferência usando apenas o dado de expressão, não há ganho pois não há uso de informação de proteína. O ponto $(1,1)$ corresponde a inferência utilizando apenas a informação PPI.

Observou-se que o aumento do peso do dado biológico incrementa a similaridade. Além disto, o ganho não é linear e as medidas apresentaram comportamentos distintos. O ganho na precisão indica o potencial de evitar falsos positivos e o ganho em sensibilidade, o potencial em identificar verdadeiros positivos. A precisão cresce linearmente até $w_{2}=0.5$, após este valor, o crescimento fica abaixo do que seria um aumento linear do ganho. A sensibilidade apresentou um ganho muito mais significativo. Por exemplo, para $w_{2}=0.5$ (pesos iguais para expressão e dado biológico) o valor do ganho na sensibilidade é igual a 0.9 , indicando um potencial maior que a informação tem para identificar novos relacionamentos. Por outro lado, embora a precisão cresça com o peso do dado biológico, quando a sensibilidade aproxima-se do máximo a precisão ainda atinge 0.7. Isso aponta para uma limitação em reduzir falsos positivos mas em um potencial para identificar verdadeiros positivos. O falso positivo significa que existe uma relação entre a expressão do par de genes que não 
é suportada por uma interação entre suas proteínas correspondentes. O verdadeiro positivo indica uma relação entre a expressão do par de genes para a qual existe também uma interação entre as proteínas codificadas por eles. Assim, a limitação em reduzir FP é esperada, pois a informação de uma interação entre proteínas tem um potencial menor de eliminar a inferência de uma relação entre a expressão dos genes, mas contribui para identificar novas relações entre expressão gênica suportadas por interação entre proteínas e que não seriam identificadas sem o dado PPI.

\subsubsection{Rosetta Stone e KEGG}

Também se avaliou a combinação de informações biológicas. Há uma limitação prática na construção de datasets para validação compostas por diferentes dados. No entanto, como apresentado no Capítulo 3, construímos quatro datasets de interseção que compreendem redes menores (IGS1, IGS2, IGS3, IGS4). Embora as redes sejam menores, o uso destes dados apresentou características similares aos conjuntos de dados maiores. Em todos, o ganho não foi linear com o aumento do peso. Além, disto sempre houve ganho com adição da informação biológica, como esperado.

A Figura 4.2 apresenta o resultado da combinação do dado Rosetta Stone e KEGG. Novamente o comportamento não é linear e o ganho em sensibilidade é melhor que o ganho em precisão. O resultado indica um potencial do dado de via metabólica para identificar novos relacionamentos que ocorrem tanto na expressão quando nas vias metabólicas. As vias metabólicas descrevem relações entre proteínas mas não necessariamente interação direta entre as proteínas codificadas pelos genes. Neste exemplo existe uma aresta na rede KEGG se os genes participam da mesma via metabólica. É interessante notar que mesmo não havendo interação física, há uma relação com o dado de expressão quando os genes estão envolvidos na mesma via, e o dado de KEGG contribui para recuperar este tipo de relacionamento. O mesmo acontece para o dado de interação entre proteínas obtido indiretamente pela metodologia Rosetta Stone. 


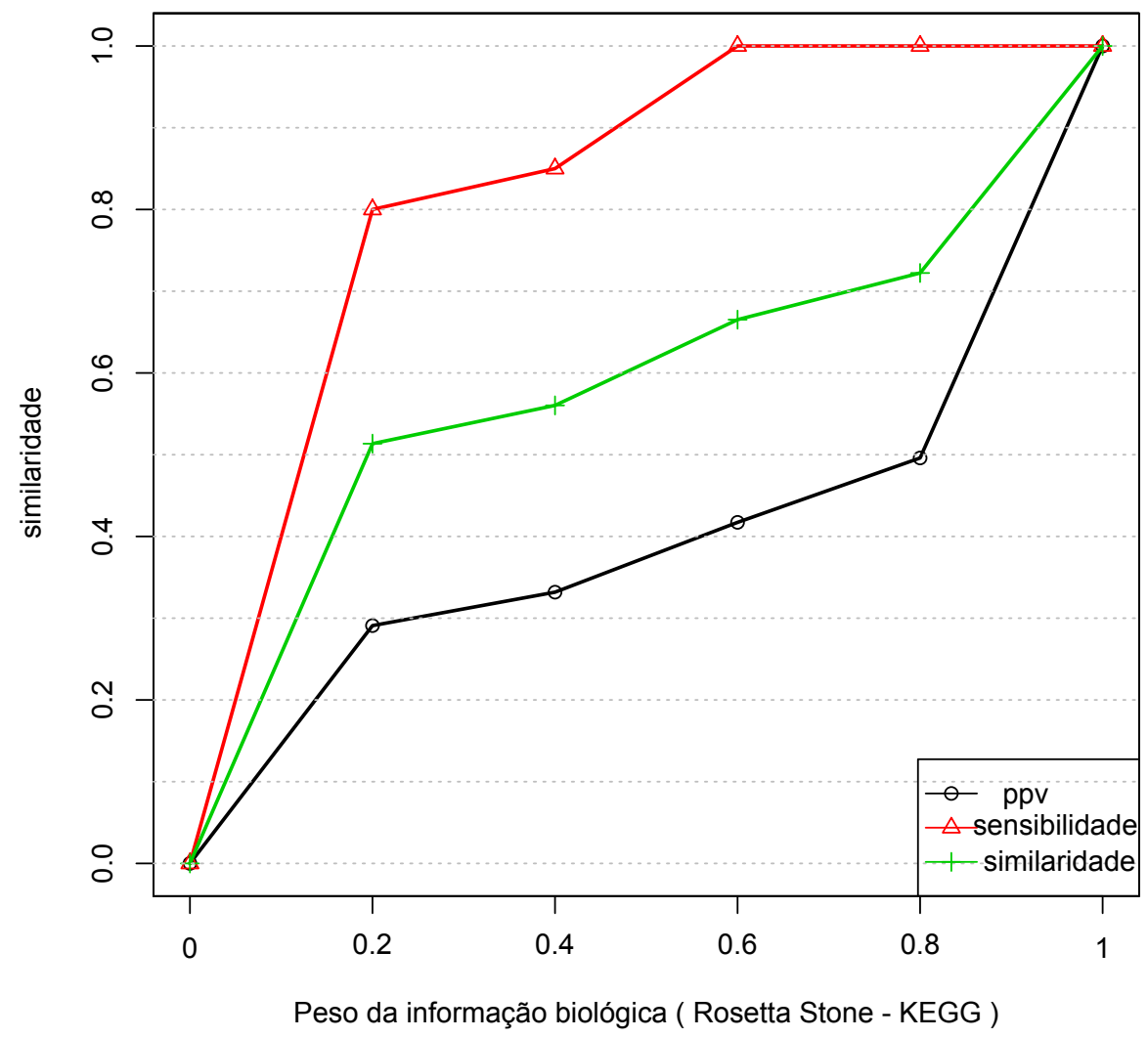

Figura 4.2: Rosetta Stone e KEGG. Variação da Similaridade, PPV e Sensibilidade pela variação do peso do dado biológico. A contribuição do dado não é linear e o ganho em Sensibilidade é maior que o ganho em precisão.

A Figura 4.3 mostra o resultado da inferência com o dado combinado de KEGG, Rosetta Stone e Gene Ontology. As curvas são similares com a ganho maior em sensibilidade do que em precisão. Outro resultado interessante é que o dado Rosetta Stone Protein apresentou comportamento similar ao dado de interação proteína-proteína. Isto pode ser explicado porque este dado fornece o mesmo tipo de informação que o dado de PPI, isto é, sobre a interação física direta entre as proteínas correspondentes aos genes da rede.

\subsubsection{Genes HUB}

Também foram analisados os resultados com respeito aos genes hub da rede. Como discutido no Capítulo 2, alguns trabalhos apontam que redes biológicas tendem a apresentar topologias particulares como redes scale-free. Nestas redes espera-se que um pequeno número de genes possua um grande número de interações (hubs) e que a maioria dos genes possua um número bem menor de relacionamentos [Barabási et al., 2011]

Assim, avaliou-se também o ganho considerando-se a subrede composta apenas pelos genes $h u b$ e suas interações. A rede dos genes $h u b$ foi definida como a rede formada pelos $10 \%$ dos vértices de maior grau e os respectivos vértices a que estão conectados.

A Figura 4.4 apresenta o resultado para o dado de interação de proteínas (Rosetta Stone). A análise mostrou que há uma inversão no ganho entre sensibilidade e precisão. Uma possível 


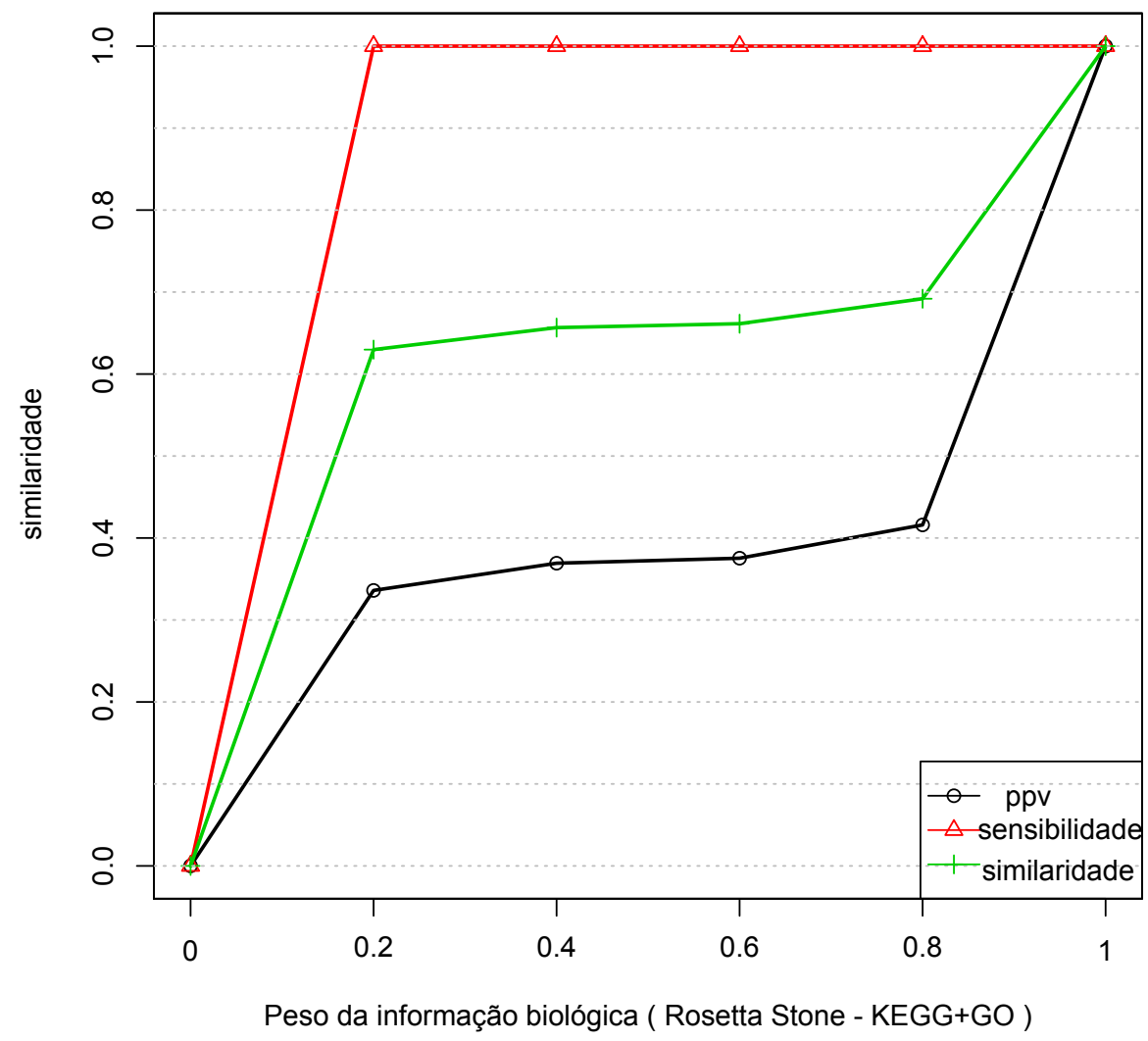

Figura 4.3: Rosetta Stone, KEGG e GO. Variação da Similaridade, PPV e Sensibilidade pela variação do peso do dado biológico. A contribuição do dado biológico não é linear e o ganho em Sensibilidade é maior que o ganho em precisão.

explicação é que os genes $h u b$ podem ser fatores de transcrição importantes que regulem vários genes. Assim, esta rede deixou de fora outras relações menos evidentes tanto nos dados de expressão quanto nos dados de interação.

A Figura 4.5 apresenta os resultados de ganho para a rede $h u b$ com uso de dados do KEGG. Os dados de KEGG, assim como os dados de GO quando aplicados isoladamente apresentam comportamento semelhante. O ganho não é linear, mas ao contrário dos dados de PPI e Rosetta Stone, o ganho fica abaixo do que seria um ganho linear. O resultado sugere uma limitação deste tipo de dado biológico em termos de potencial para melhorar o ganho.

É importante notar que os dados de PPI e de Rosetta Stone informam relação física direta enquanto que os dados do KEGG e GO informam uma relação diferente de interação física, isto é, indicam a participação em uma mesma via ou associação da função. Assim, com respeito à tentativa de classificar os tipos de dados biológicos, estes poderiam ser classificados inicialmente em dois grupos: (a) dado sobre relação física direta e (b) dado sobre associação indireta (localização celular, função, via metabólica, etc.). 


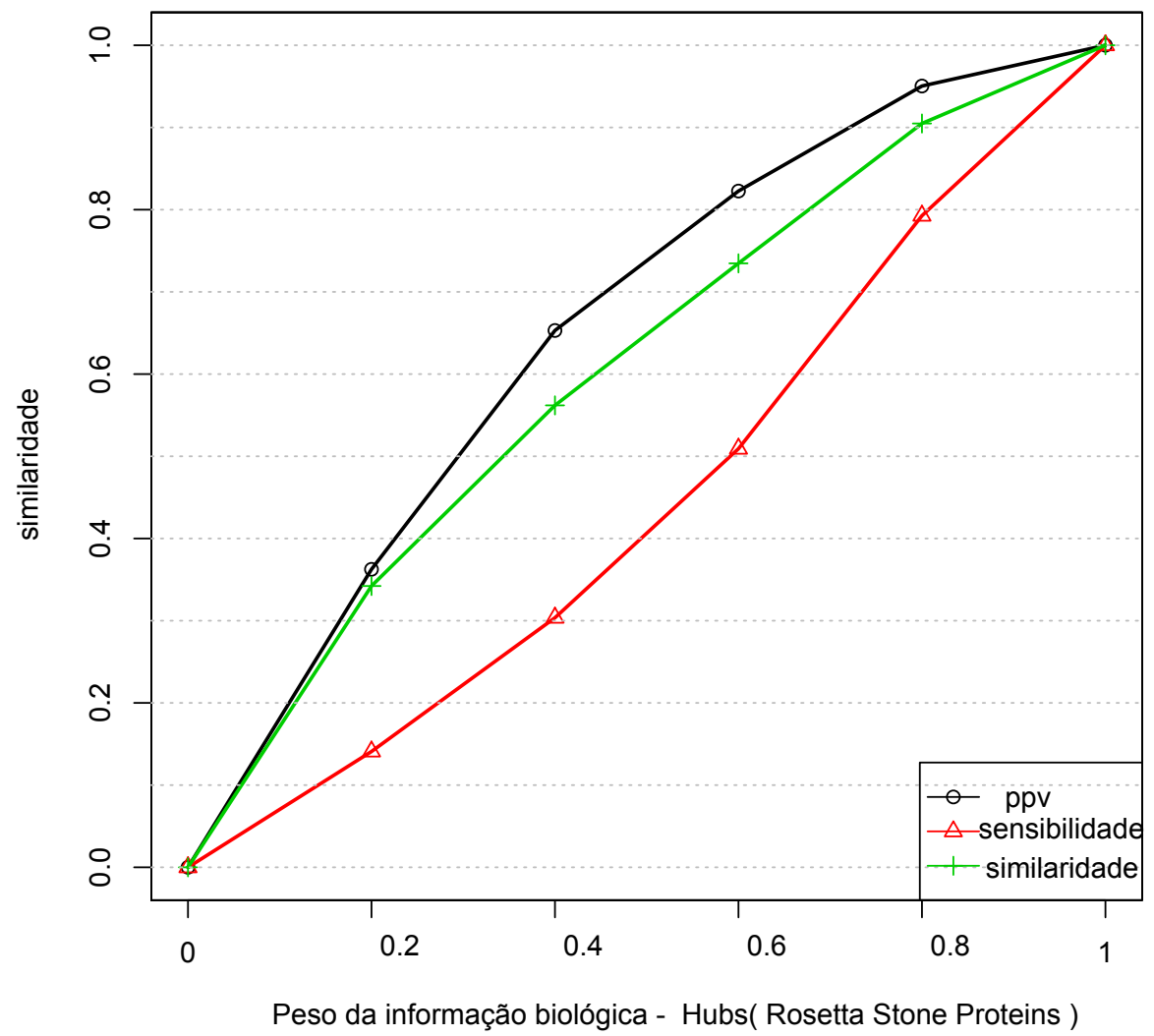

Figura 4.4: Avaliação com a rede formada pelos genes hub e inferência com dados de interação de proteína (Rosetta Stone). Variação da Similaridade, PPV e Sensibilidade pela variação do peso do dado biológico. A contribuição do dado biológico não é linear e o ganho em Sensibilidade é maior que o ganho em precisão. 


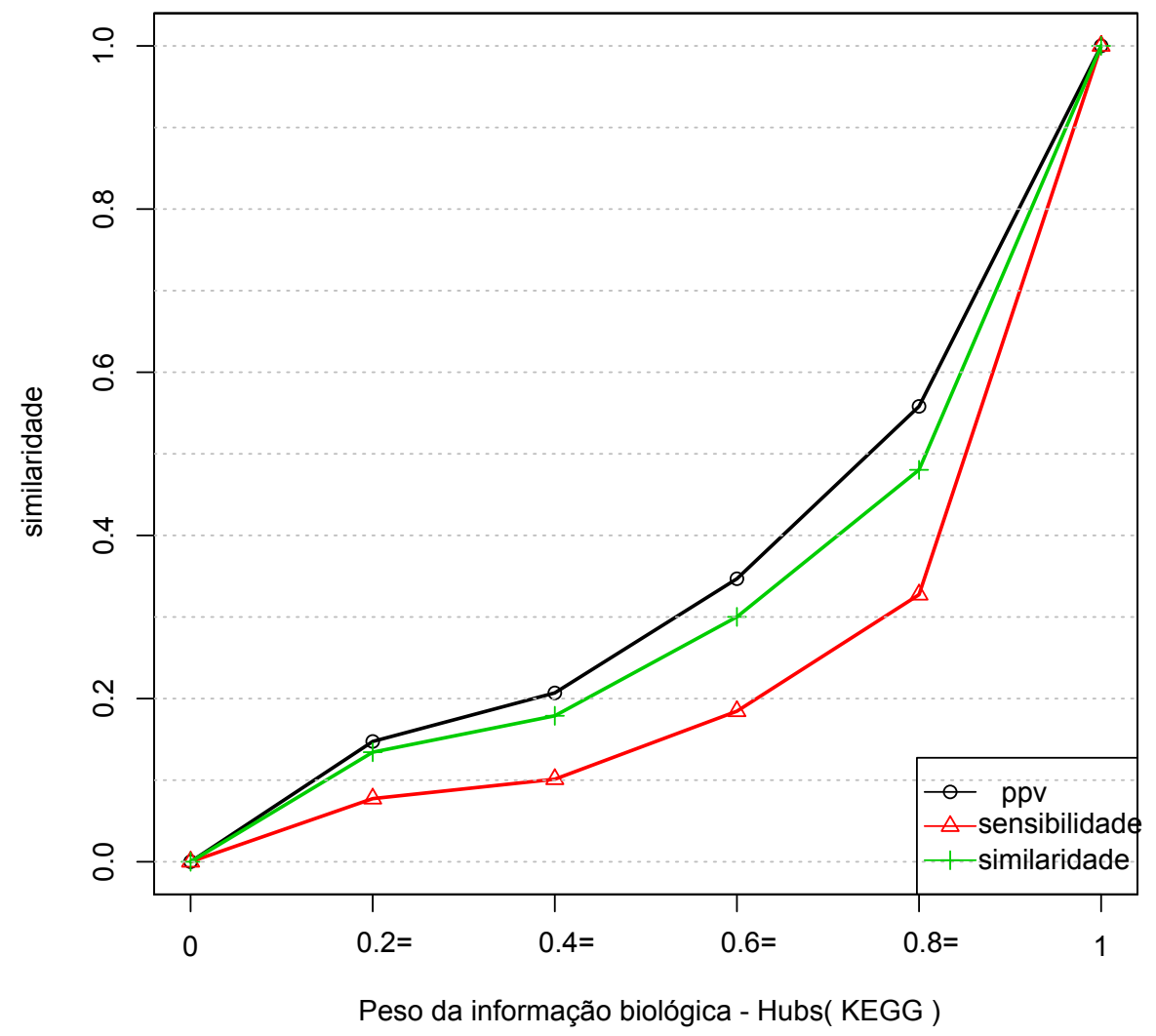

Figura 4.5: Avaliação com a rede formada pelos genes hub e inferência com dados do KEGG. Variação da Similaridade, PPV e Sensibilidade pela variação do peso do dado biológico. A contribuição do dado biológico não é linear e o ganho em Sensibilidade é maior que o ganho em precisão.

\subsection{SFFS-SW}

\subsubsection{Avaliação da similaridade, precisão e sensibilidade do método}

O método de inferência SFFS-SW foi avaliado utilizando-se redes gênicas artificiais (AGN). Para isto foram geradas redes com 100 vértices e grau médio $k$ variando de 1 a 4 . O parâmetro de redirecionamento de arestas do modelo gerador de Watts e Strogatz foi ajustado para $p=0.01$. Este parâmetro determina o grau de aleatoriedade da rede gerada e de acordo com [Strogatz, 2001] o valor definido garante valores característicos para o coeficiente de clustering e caminho mínimo médio. O limiar da função critério foi ajustado para 0.3. Para cada configuração foram realizadas 10 execuções. Cada execução produziu uma rede na primeira estapa do algoritmo, conforme descrito na Seção 3.2.3. Na segunda etapa do algoritmo, para cada execução, variou-se o peso da topologia com os valores $0.2,0.4,0.6,0.8,1.0$. Para cada valor de peso, o algoritmo de busca iniciou sempre da mesma rede inferida na etapa 1 daquela configuração de parâmetros.

Assim, para cada uma das execuções, obteve-se a rede inferida apenas com dados de expressão e redes inferidas com variados valores do peso da informação topológica.

É importante que as características topológicas não anulem a informação do dado de expressão. Uma das questões importantes é encontrar a combinação ideal de peso que maximize a acurácia da 
predição.

A Figura 4.6 mostra a variação da precisão conforme a variação do peso da informação topológica e variação do grau médio.

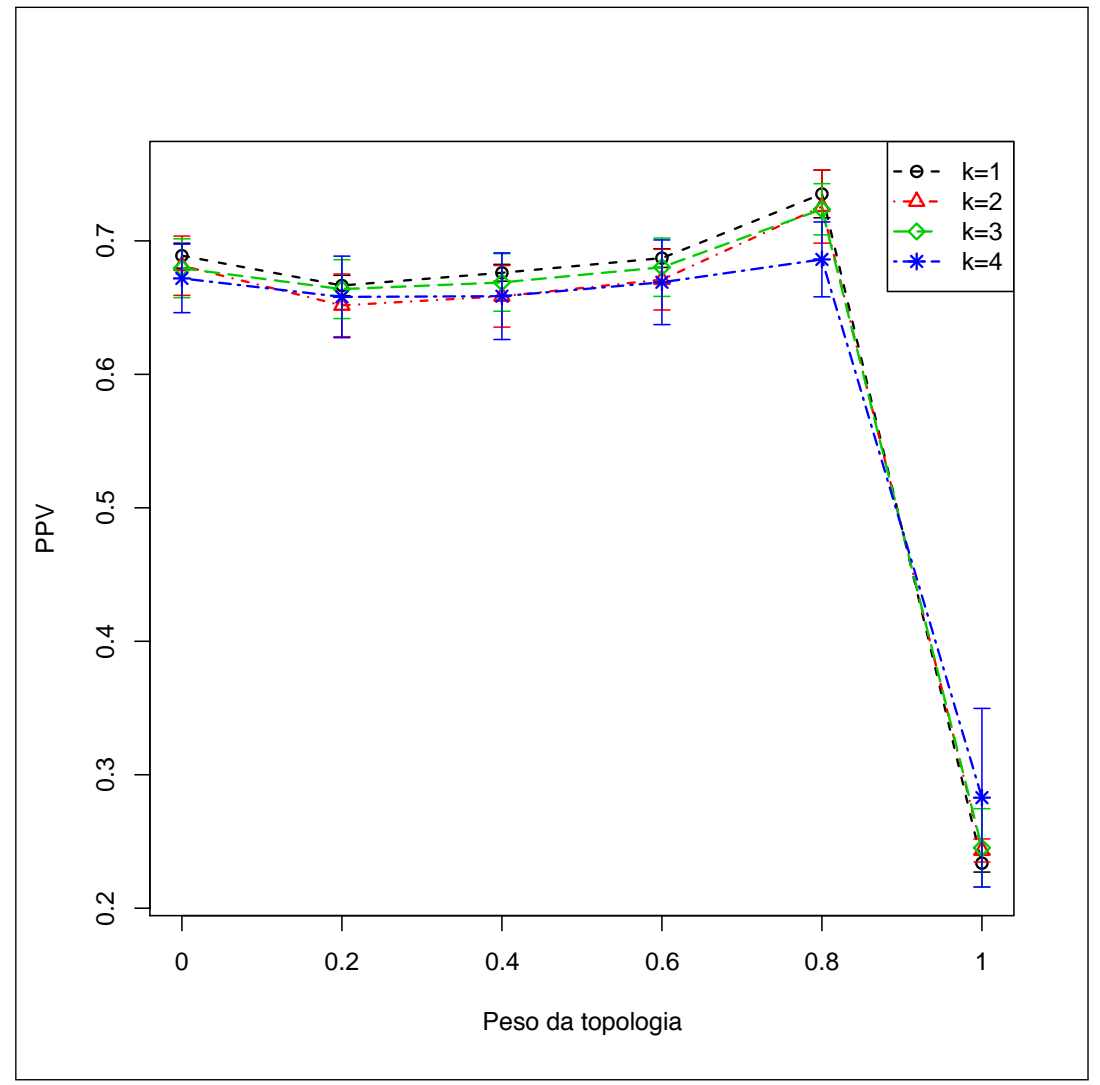

Figura 4.6: Precisão (PPV) do algoritmo SFFS-SW de acordo com a variação do peso da informação topológica. $O$ algoritmo atinge o melhor resultado para peso $w=0.8$ para qualquer valor de $k$. A precisão decresce rapidamente quando o algoritmo reduz o peso do dado de expressão, chegando próximo de zero quando o ignora $(w=1.0)$. Este comportamento mostra que tanto expressão quanto a informação topológica são necessários para aumentar a acurácia do método.

Independente do grau dos vértices $k$, o algoritmo atinge o valor máximo de precisão para peso $w=0.8$. Um ponto importante no resultado é que, a partir de um certo limiar (no caso 0.8), quando o peso do dado de expressão diminui muito, a precisão também reduz drasticamente. Isto sugere que ambos, expressão e característica topológica, são necessários para melhorar a precisão. Também sugere uma interdependência entre a topologia e a dinâmica da expressão. Além disto, é importante notar que a inferência não é dominada pela característica topológica, isto é, a precisão não é prejudicada ao forçar um viés topológico pelo aumento do peso da topologia. Em outras palavras, o viés topológico não só melhora a inferência da rede no sentido de recuperar uma rede com as características desejadas como melhora a precisão.

A Tabela 4.1 mostra os valores de precisão, sensibilidade e similaridade para diferentes valores de grau médio $k$. Em geral, as medidas de acurácia melhoram com o uso da informação topológica. 
Tabela 4.1: Precisão (PPV), Sensibilidade (Recall) e Similaridade para $k=1,2,3,4$ e pesos $=$ $0,0.2,0.4,0.6,0.8,1.0$

\begin{tabular}{|c|c|c|c|c|c|c|c|}
\hline & \multicolumn{6}{|c|}{ weight } \\
\hline & & 0 & 0.2 & 0.4 & 0.6 & 0.8 & 1.0 \\
\hline \multirow{3}{*}{$\mathrm{k}=1$} & PPV & 0.56 & 0.54 & 0.55 & 0.56 & 0.60 & 0.10 \\
\hline & Sensitivity & 0.78 & 0.80 & 0.80 & 0.80 & 0.80 & 0.09 \\
\hline & Similarit & 0.76 & 0.75 & 0.76 & 0.76 & 0.78 & 0.20 \\
\hline \multirow{3}{*}{$\mathrm{k}=2$} & PPV & 0.60 & 0.57 & 0.58 & 0.59 & 0.65 & 0.11 \\
\hline & Sensitivity & 0.58 & 0.59 & 0.58 & 0.58 & 0.58 & 0.05 \\
\hline & Similarity & 0.70 & 0.69 & 0.69 & 0.70 & 0.72 & 0.18 \\
\hline \multirow{3}{*}{$\mathrm{k}=3$} & $\mathrm{PPV}$ & 0.62 & 0.60 & 0.61 & 0.62 & 0.67 & 0.13 \\
\hline & Sensitivity & 0.44 & 0.45 & 0.45 & 0.44 & 0.44 & 0.10 \\
\hline & Similarity & 0.65 & 0.64 & 0.64 & 0.65 & 0.66 & 0.10 \\
\hline \multirow{3}{*}{$\mathrm{k}=4$} & PPV & 0.67 & 0.66 & 0.66 & 0.67 & 0.69 & 0.28 \\
\hline & Sensitivity & 0.39 & 0.39 & 0.39 & 0.39 & 0.35 & 0.01 \\
\hline & Similarity & 0.64 & 0.64 & 0.63 & 0.64 & 0.62 & 0.12 \\
\hline
\end{tabular}

\subsubsection{Avaliação da trajetória das medidas de caracterização}

A metodologia de avaliação de inferência de redes é importante e não restringe-se à comparação com uma rede gold standard [Dougherty, 2007]. Geralmente avalia-se apenas a proporção de arestas inferidas corretamente. No entanto, há outros aspectos importantes a serem considerados na avaliação como a dinâmica da rede inferida, entre outros.

Como contribuição deste trabalho, foi proposto a avaliação da trajetória das medidas de caracterização da rede complexa. A trajetória de uma rede complexa é obtida pela sucessão de vetores de características da topologia da rede [Costa et al., 2007a]. Assim, analisou-se a trajetória do coeficiente de clustering $C$ e do caminho mínimo médio $L$. É importante verificar se a rede inferida realmente apresenta um viés para as características topológicas desejadas. A Figura 4.7 apresenta a trajetória do coeficiente de clustering.

Nota-se uma aproximação da característica topológica desejada (coeficiente de clustering alto) a partir da etapa 2 do algoritmo SFFS-SW.

O algoritmo apresentou um comportamento diferente na trajetória de $L$. O caminho mínimo cresce rapidamente nos primeiros passos da etapa 1. A explicação é que a rede inicia sem nenhuma aresta e é construída a medida que os genes alvos são avaliados. Após um certo ponto, ainda na etapa 1, a medida decresce até atingir o valor indicado pelo ponto que toca a linha tracejada na Figura 4.8. Ao contrário do coeficiente de clustering, o valor de $L$ não varia muito na etapa 2. Uma explicação possível é que o menor caminho mínimo é atingido rapidamente, devido as características da rede SW. Assim, a etapa 2 tende a manter o valor obtido na etapa 1. 


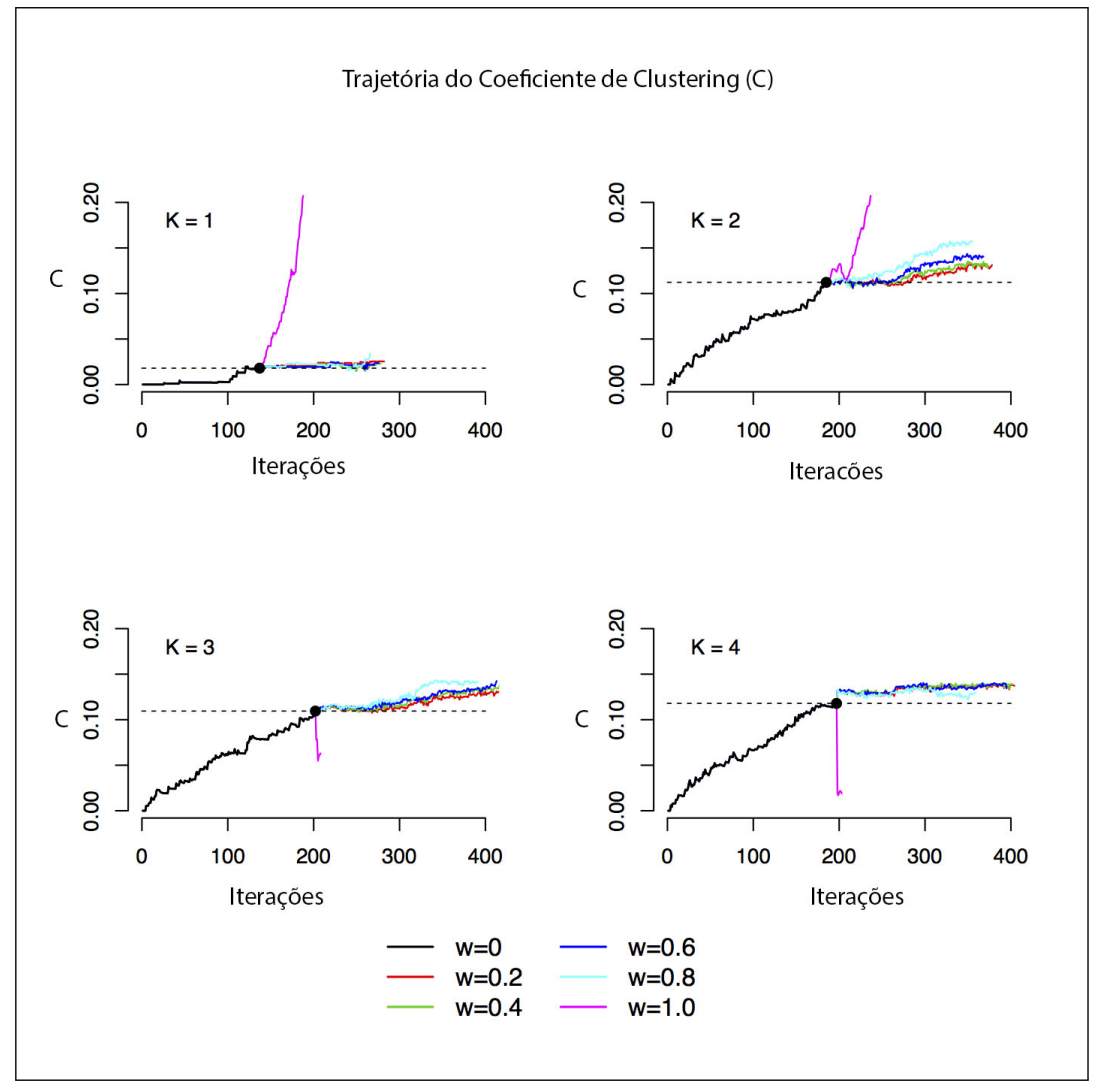

Figura 4.7: Trajetória do coeficiente de clustering para diferentes valores de $k=1,2,3,4$. A linha $w=0$ mostra a inferência na fase 1 do algoritmo SFFS-SW (apenas com dado de expressão). O ponto em destaque indica o início da fase 2 quando a informação topológica é usada. Nota-se que há um aumento gradual do coeficiente de clustering, independente do peso, indicando que a cada nó revisitado, o conjunto de preditores escolhido é mais coerente com a topologia global do que na fase 1. 


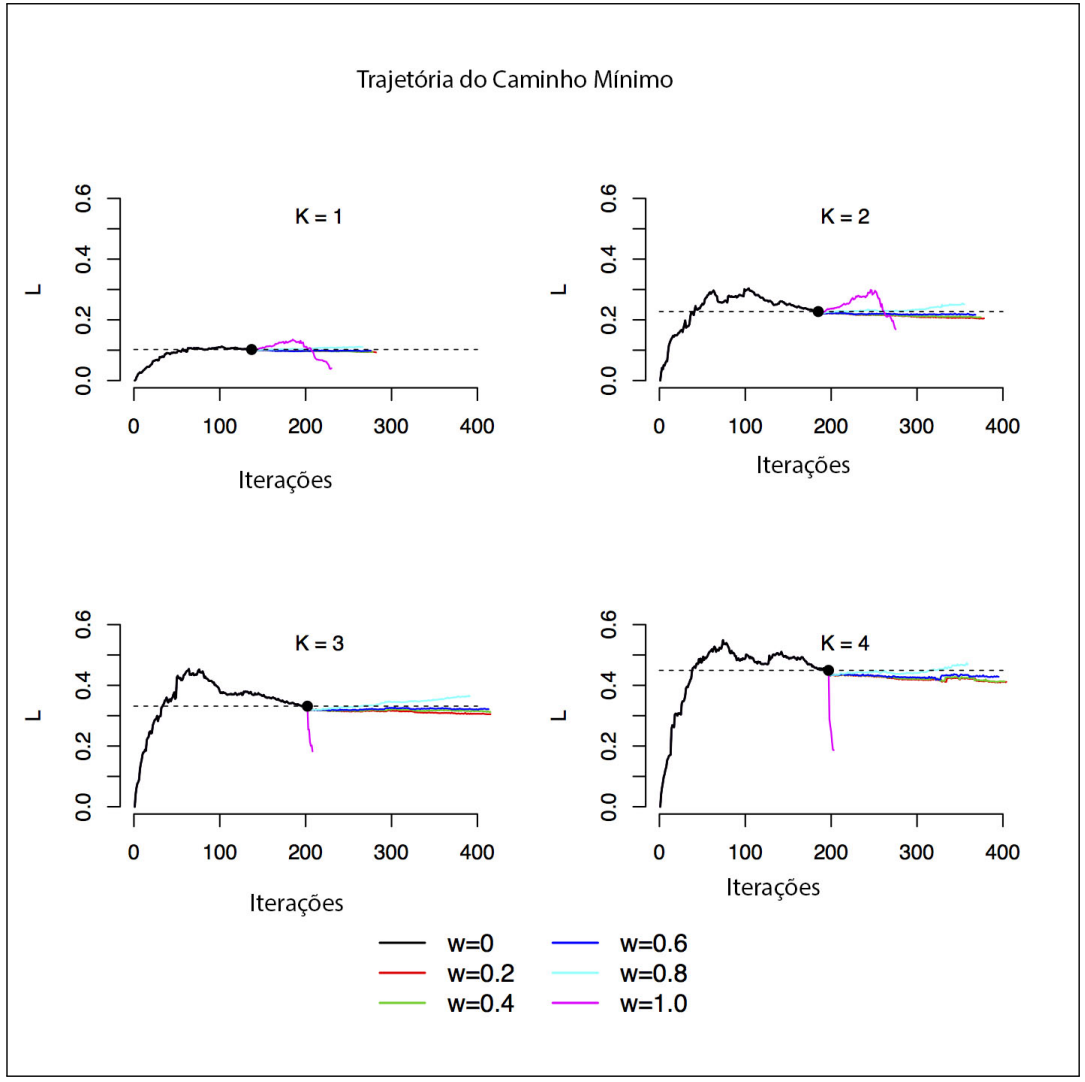

Figura 4.8: Trajetória do caminho minimo médio para diferentes valores de $k=1,2,3,4$. A linha $w=0$ mostra a inferência na fase 1 do algoritmo SFFS-SW (apenas com dado de expressão). O ponto em destaque indica o início da fase 2 quando a informação topológica é usada.

\subsection{Integração de dados em Arabidopsis thaliana}

\subsubsection{Conjunto de dados de validação}

Uma das contribuições deste trabalho foi a construção de um conjunto de dados para inferência e validação de modelos de integração de dados em inferência de redes. A anotação de genes em bancos de dados públicos fornece informações de tipos e formas variadas. Muitas vezes a anotação está no formato textual, listada em tabelas, em arquivos de bancos de dados ou em arquivos de texto simples (flat files). Os dados podem ser descritivos, algumas vezes adotando convenções para uso de termos. Neste trabalho os dados disponíveis nas três fontes de dados diferentes conforme descritos no Capítulo 3 foram obtidos, preprocessados, organizados e disponibilizados.

Neste trabalho foram selecionados 3 das 15 características disponíveis no dataset criado, relacionadas a aspectos físicos e a atividade do gene: (i) cellular location, (ii) pathway e (iii) function.

O conjunto de dados para validação construído é descrito na Tabela 4.2.

Tabela 4.2: $O$ conjunto de dados de valiação possui 5.974 genes.

\begin{tabular}{|c|c|c|}
\hline Conjunto de dados & Descrição & Quantidade \\
\hline Rede gold standard & Arestas & 8.589 \\
Dado de expressão data & Amostras & 1.206 \\
Características biológicas & Características & 3 \\
\hline
\end{tabular}




\subsubsection{Avaliação dos resultados}

Os resultados dos experimentos apresentaram características distintas com relação às diferentes informações biológicas usadas (Figura 4.9). A localização melhorou a similaridade com o aumento do peso até o valor $w=0.7$; após este valor a similaridade decresceu. Este comportamento indica que ambos os dados, expressão e localização, são necessários para melhorar a acurácia do método. Em outras palavras, o uso apenas do dado de expressão ou uso apenas do dado de localização geram resultados piores do que estas informações combinadas. Para localização e via metabólica, o resultado foi inverso. Uma explicação possível é que a rede regulatória (gold standard) refere-se a interações físicas diretas enquanto que o dado de via metabólica e função referem-se a relações indiretas. Este mesmo aspecto foi observado nos trabalhos anteriores com Plasmodium falciparum. Os resultados sugerem que informações físicas têm um potencial maior para melhorar a acurácia e que informações de outros tipos devam ser usadas com cautela.

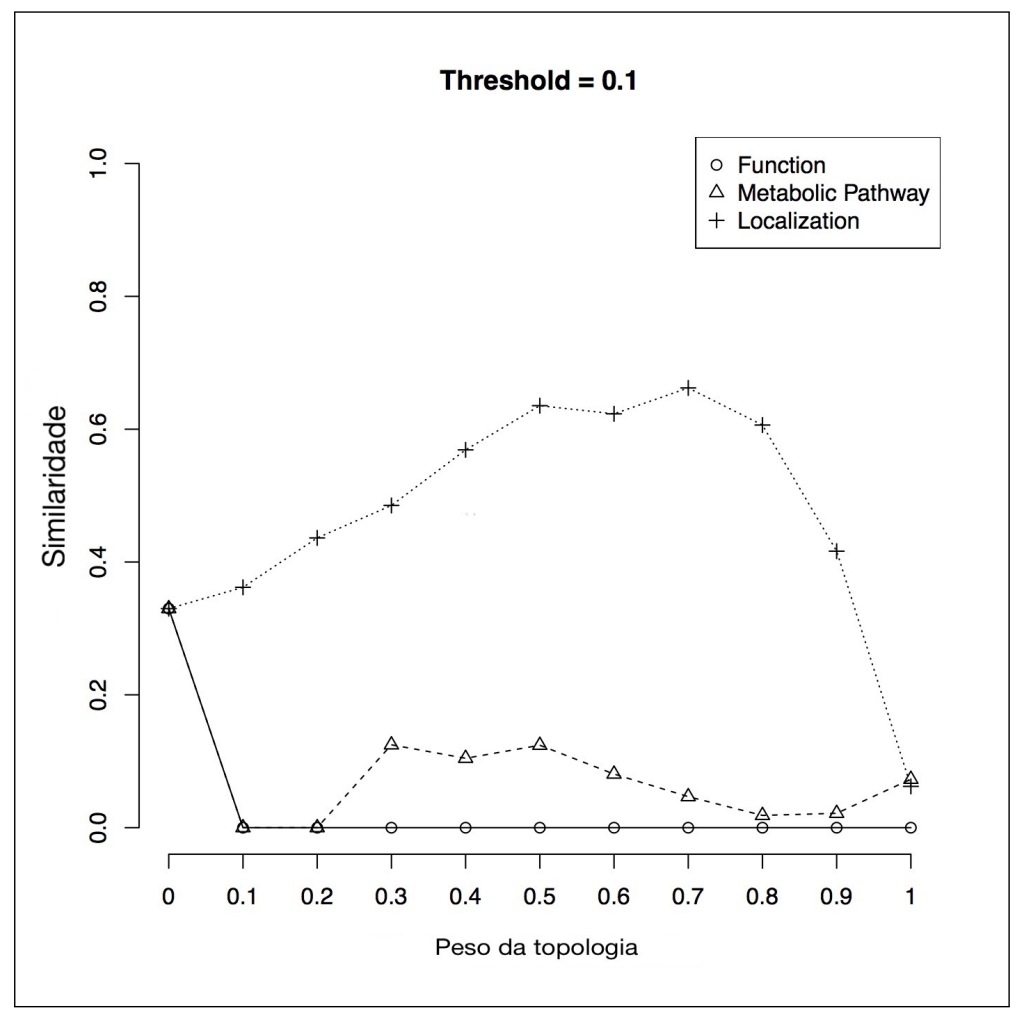

Figura 4.9: Similaridade entre a rede inferida e a rede regulatória de Arabidopsis com respeito à variação do peso do dado biológico. O dado de localização (que informa localização física) apresentou melhor resultado que os demais dados (informação funcional e da vida metabólica).

A Figura 4.10 mostra a variação da similaridade para diferentes thresholds da função critério quando a informação sobre localização é usada.

A similaridade cresce mais rapidamente com o peso do dado biológico para valores menores de thresholds da função critério. O valor menor da função critério é mais restrito, e corrobora com a redução de falsos positivos. Independente do threshold, o comportamento é o mesmo: a partir de um certo valor do peso $w$, a acurácia decai drasticamente, indicando importância da contribuição de ambos os tipos de informação. 


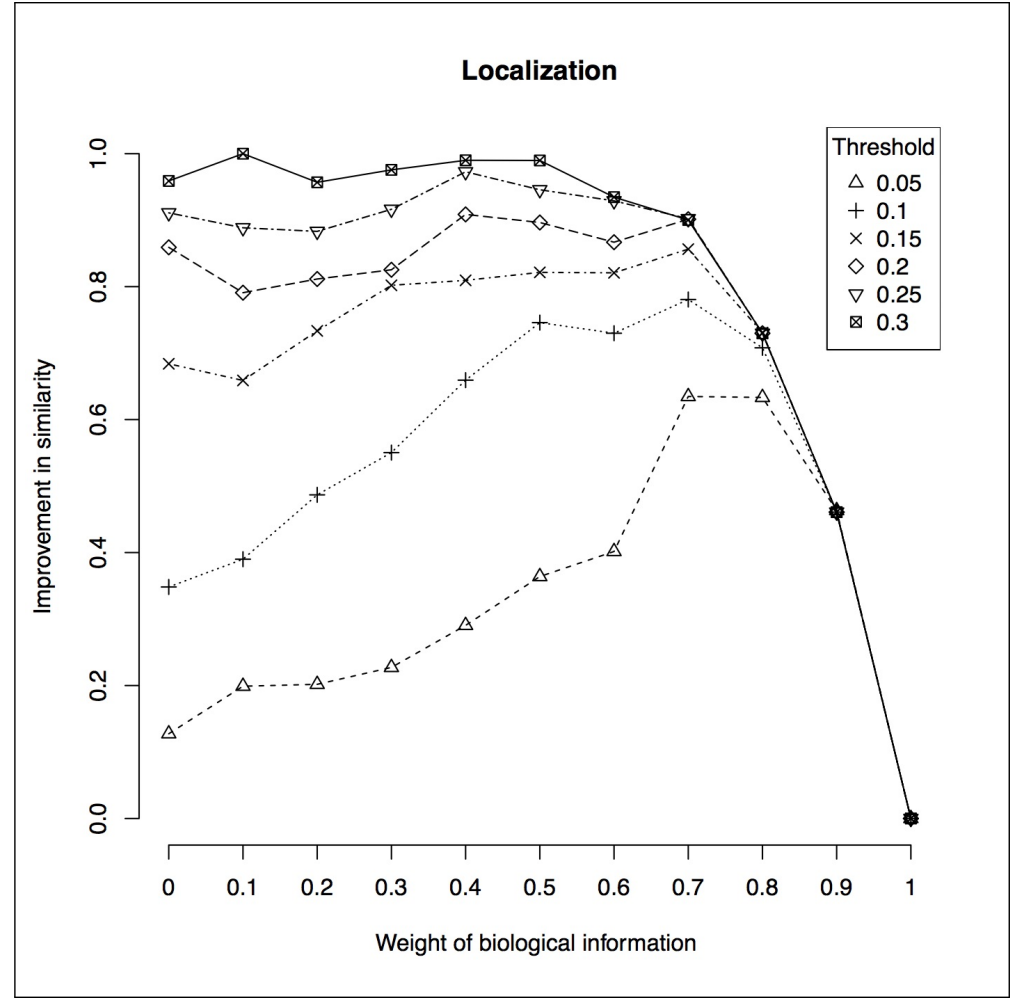

Figura 4.10: Avaliação da similaridade com a variação do peso do dado biológico de localização, para diferentes thresholds da função critério. 


\section{Capítulo 5}

\section{Conclusão e trabalhos futuros}

\subsection{SFFS-BS e dado biológico}

No primeiro trabalho de avaliação de ganho de dado biológico além do dado de expressão, utilizamos séries temporais de dados de expressão do trabalho de [Bozdech et al., 2003] pré-processados com filtragem, normalização e quantização no trabalho de [Barrera et al., 2004]. Os dados também foram obtidos de trabalhos publicados [Lamesch et al., 2011, Yilmaz et al., 2011]. Foi proposto um modelo de integração de dados baseado em uma função critério que combina dados de expressão e informação biológica a priori. Os dados de expressão são avaliados pelo cálculo da MCE e um peso foi atribuído a cada dado. Os resultados mostraram que a inclusão do dado de interação proteínaproteína (PPI) contribuíram para melhorar a precisão e a sensibilidade do método de inferência.

Em particular, o ganho é diferente entre precisão e sensibilidade; a precisão teve um baixo ganho pelo aumento do peso do dado biológico enquanto a sensibilidade cresceu rapidamente, chegando próximo ao máximo com um peso do dado biológico igual a 0.5. Portanto, os resultados sugerem que a inclusão de conhecimento biológico a priori tem um potencial maior para a descoberta de relações existentes (true positives) do que para evitar falsos positivos.

O dado de PPI fornece uma informação a priori sobre a interação física direta entre os produtos dos genes. Como complemento do estudo sobre o dado de PPI, outros três tipos de dados foram testados: interação entre proteínas obtidas de sequências genômicas, vias metabólicas e ontologia. Os resultados mostraram que dados de interação de proteínas tem potencial maior para melhorar a precisão e a sensibilidade da inferência. Assim, sugerimos a classificação dos dados em dois grupos: (a) dados que informam interação física direta e (b) dados que informam relações funcionais ou relacionamentos indiretos. Outra conclusão importante dos resultados é o fato que os dados de interação de proteínas, mesmo quando obtidos indiretamente a partir de sequências, possibilitaram resultado muito similar àqueles obtidos por meio de Y2H. Isto aponta para a possibilidade de utilizar sequências genômicas como fonte de informação já que este tipo de dado é abundante.

\subsubsection{Trabalhos futuros}

\section{Integração de amostras negativas}

Uma das dificuldades de criar modelos de inferência e avaliá-los no campo da biologia, em especial das redes gênicas, é a ausência de dados de interações inexistentes, isto é, um negative gold 
standard. Em geral os experimentos são realizados com o objetivo de descobrir interações existentes entre os genes e a ausência de uma relação pode ter dois significados: (a) a relação não existe, é impossível ou (b) a relação existe mas não foi observada. No entanto, há alguns conjuntos de dados de amostras negativas (isto é, indicam que uma interação certamente não existe) que poderiam ser utilizados. Além disto, um especialista (biólogo) poderia enumerar um conjunto de interações que considere impossíveis ou mesmo pouco prováveis. Neste sentido, desenvolver modelos para integração de exemplos negativos poderia reduzir o número de falso positivos.

\section{Informação de sequência genômica}

Como dito anteriormente, o dado de sequência genômica apresentou resultado semelhante ao dado de PPI. Neste trabalho utilizou-se uma fonte de dados pronta, pré-processada e já publicada. Um desafio interessante é investigar outras formas de incluir dados de sequência genômica na inferência. Visto que este é um dado abundante, seu uso poderia contribuir significativamente para a inferência de redes. Como exemplo, considere os dados de Sítio de Ligação de Fator de Transcrição (TFBS, do inglês Transcription Factor Binding Sites) descritos como PSSM (do inglês Position Specific Scoring Matrix). Uma PSSM é uma representação probabilística de um TFBS que permite calcular a probabilidade de uma dada sequência de DNA conter um TFBS para um dado TF específico. Um modelo de integração de dados poderia utilizar uma base de dados de PSSM mais uma base de dados de sequências de DNA upstream dos genes alvo e calcular on line a probabilidade do gene alvo conter um sítio para ligação do preditor avaliado.

\section{Medida de distância em dados de ontologia de genes}

O GO é uma fonte oficial de informação sobre a ontologia de genes sobre três aspectos: (a) componente celular (e.g. citoplasma), (b) função molecular (e.g. Fator de Transcrição), (c) Processo biológico (e.g. fosforilação oxidativa). A informação está organizada de forma hierárquica onde cada componente é descrito como "é parte de" outro componente. Do ponto de vista computacional a estrutura é um DAG, um grafo acíclico dirigido. Na anotação, cada gene pode estar associado a um ou mais números GO, que informam os 3 aspectos descritos acima. Portanto, uma vez que um subconjunto de genes estejam associados através de algum processo, é possível questionar se os elementos compartilham um termo GO. No entanto, os genes podem ter sido anotados com termos GO diferentes mas que em algum nível no DAG compartilhem um termo comum. Para ilustrar este cenário considere a Figura 5.1.

Por exemplo, se dois genes $A$ e $B$ forem preditos como relacionados e compartilharem o mesmo termo GO "celular metabolism", a evidência de que tenham uma interação física direta será fraca uma vez que "metabolismo" é um processo muito abrangente, isto é, muitos genes participam de metabolismo. Porém, se o processo biológico compartilhado pelos genes for algo "faty acid metabolism" como ilustrado na Figura 5.1 a evidência de que estejam de fato ligados será maior já que o processo é mais específico que "metabolismo" e pode ser pouco provável que genes tomados ao acaso participem deste processo; havendo indícios também nos dados de expressão a possibilidade de interação será ainda maior.

Além disto, sendo o GO organizado como um DAG, é possível saber em qual profundidade os genes compartilham o mesmo termo GO. A profundidade pode ser usada como uma informação quantitativa ao invés de uma informação nominal como a usada no trabalho. 


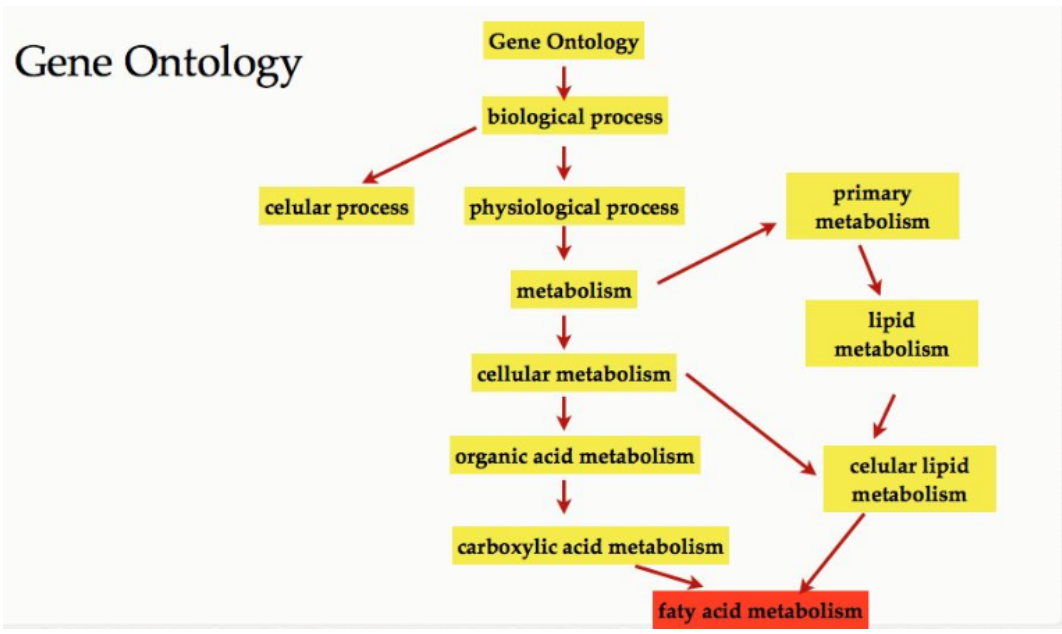

Figura 5.1: Exemplo de uma estrutura de Ontologia de Genes (Gene Ontology - GO)

Por exemplo, tomando ainda a Figura 5.1, suponha que um gene $A$ esteja anotado como "carboxilic acid metabolism" e que o gene $B$ como "celular lipid metabolism". São termos GO diferentes, porém "carboxilic acid metabolism" é um "organic acid metabolism" que é um "celular metabolism" e "celular lipid metabolism" também é um "celular metabolism". Assim, ambos estão relacionados ao metabolismo celular. Contando a partir da raiz, este termo está no nível 4 do DAG. Se ambos compartilhassem o termo "faty acid metabolism" estariam no nível 7 do DAG, portanto mais específico. Deste modo, um algoritmo de inferência que incorpore o DAG do GO poderia calcular, sob demanda, o nível do DAG em que preditores e alvos compartilham um termo GO. Este valor pode ser usado para melhorar a precisão do método de inferência.

\subsection{SFFS-SW}

Os resultados do método SFFS-SW mostraram que a informação topológica contribuiu para melhorar a inferência de redes de topologia Small World. O algoritmo SFFS-SW inferiu redes com características topológicas mais próximas de uma rede SW do que o algoritmo SFFS (fase que não inclui informação topológica).

Um resultado importante a se destacar é que é necessário não apenas encontrar arestas corretas e descartar incorretas, mas inferir um conjunto de arestas que sejam consistentes com a topologia desejada da rede. Neste sentido, embora a busca no SFFS-SW seja feita localmente (avaliando um gene alvo por vez), o algoritmo conseguiu atingir um efeito global, inferindo uma rede com características SW.

\subsubsection{Trabalhos futuros}

\section{Algoritmo para otimização dos pesos}

Um ponto importante no resultado é a interdependência entre dado de expressão e informação topológica. O resultado sugere a existência de um valor ótimo para o peso entre informação topológica e dado de expressão. Como trabalho futuro, é interessante estudar um algoritmo de otimização, preferencialmente que encontre o valor ótimo automaticamente durante a inferência. 


\section{Melhorar o custo computacional do algoritmo}

$\mathrm{Na}$ versão atual o algoritmo tem um alto custo computacional. A principal razão é o cálculo, durante a inferência, das medidas de redes complexas, em especial o cálculo do caminho mínimo médio.

Assumindo uma rede com $N$ vértices e grau máximo $k$, o algoritmo SFFS é executado $N$ vezes, uma vez para cada gene alvo. A complexidade da computação do coeficiente de clustering médio, depende do número de vizinhos $k_{v}$ de cada vértice $v$. O algoritmo deve contar o número de arestas entre os vértices vizinhos de $v$. Assim, o número máximo de operações para cada vértice é $k^{2}$. O cálculo do caminho mais curto entre dois vértices tem custo computacional de $O\left(N^{2}\right)$ e o caminho mínimo médio é computado $N$ vezes, portanto em $O\left(N^{3}\right)$. Assim, para cada gene alvo o algoritmo calcula o caminho mínimo médio e coeficiente de clustering com um custo de $O\left(N^{3}+k^{2}\right)$ operações. Portanto, o SFFS executa $O\left(2^{k} \times\left(k^{2}+N^{3}\right)\right)$ operações. No entanto, $k$ é geralmente limitado a um valor pequeno (e.g.: 4) no contexto de inferência de redes. Assim o SFFS-SW executa em $O\left(N^{3}\right)$. Como o SFFS-SW é executado $N$ vezes, o custo de execução do algoritmo é $O\left(N^{4}\right)$. O custo é justificado pela melhora na precisão do método e pela inferência de redes com as características topológicas desejadas.

No entanto, é interessante melhorar o custo computacional já que isto permitiria a inferência de redes com um número alto de genes. Algumas abordagens podem ser investigadas na tentativa de reduzir o custo computacional como por exemplo:

- Alterar o processo de revisitar os vértices e remoção de arestas pode ser ampliado para outras formas como:

- leave one out: remover apenas 1 preditor da fase 1 por vez, evitando uma busca SFFS completa e reduzindo o custo computacional.

- leave one in: remover todos os preditores, menos 1

- eliminar a fase 1, iniciando com um grafo completo

- extrair características considerando apenas uma parte da rede com o objetivo de reduzir o custo computacional.

- avaliar o coeficiente de clustering apenas do gene alvo e de seus preditores

\subsection{Inferência de redes em Arabidopsis thaliana}

O trabalho de inferência com rede de Arabidopsis thaliana mostrou a interdependência entre os dados de expressão e o dado de localização. O resultado também sugere que a precisão pode ser prejudicada, dependendo do tipo de dado e do threshold adotado para a Entropia Condicional Média dos dados de expressão. Assim como nas avaliações com outros dados, o dado de melhor resultado foi aquele que informou relação física, isto é, localização. Os dados que fornecem informações mais genéricas como a função ou em qual via metabólica o gene atua, forneceram resultado inferior. Outro resultado importante é o ponto de valor "ótimo" para o peso do dado biológico, assim como ocorreu com o dado de topologia. A precisão cresce, independente do threshold da função critério, até um valor ótimo de peso e decresce bruscamente logo em seguida. Um dos problemas abertos é encontrar os pesos ideais para cada tipo de informação. 


\subsubsection{Trabalhos futuros: atribuição automática de pesos}

Um dos problemas abertos nas metodologias apresentadas é encontrar os pesos ideais para cada tipo de informação. Os resultados sugerem a existência de valor ótimo tanto para dado de topologia quanto para outras informações. Assim, pesquisar como atribuir pesos automaticamente, sem a intervenção do usuário, é um trabalho que pode contribuir para melhorar a similaridade do método de inferência.

\subsection{Múltiplas hipóteses e múltiplas evidências}

Está em desenvolvimento um método de integração que permita combinar dados de diferentes tipos em um único modelo de inferência, tanto topológicos quanto informações sobre relação entre genes. O método baseia-se em uma abordagem Bayesiana para casos de múltiplas hipóteses e múltiplas evidências [Pearl, 1988].

A idéia principal do método é inferir cada aresta em termos de hipótese e evidências. Chama-se de hipótese a existência ou não da regulação do gene alvo pelo conjunto de preditores. Chama-se de evidências as informações sobre a relação entre preditores e alvos, obtidos em diferentes fontes de dados. Um problema observado nos modelos propostos é que as informações biológicas são tratadas de forma equivalente. No entanto, notou-se um comportamento diferente no potencial de contribuição de cada tipo de informação. Tratar cada tipo de dado em particular pode ser tornar inviável, além de limitar o método de inferência a algumas informações em particular. O ideal seria um método mais genérico, que resolvesse a classe de problemas ao invés de problemas em particular. Outra questão que reforça este problema é que as informações biológicas são de tipos bastante heterogêneos. Por exemplo, enquanto alguns dados fornecem informação de interação física, outros fornecem informação sobre o processo biológico - este podendo ser mais ou menos específico como no caso do Gene Ontology. Ainda, há a informação sobre as características topológicas que não está diretamente associada a alguma aresta em particular.

Outra questão problemática é estabelecer a relação entre cada tipo de dado e a relação transcricional. Por exemplo, qual a relação entre uma interação PPI e uma interação TF-DNA (preditoralvo)? Em outras palavras, seria interessante quantificar esta relação, extraindo a informação dos próprios dados. Por exemplo, seria interessante responder: "dados um gene preditor $P$ e um gene alvo $A$, qual a probabilidade de $P$ regular $A$ dado que há uma interação PPI anotada sobre eles ?". Note que esta abordagem é diferente de atribuir um peso geral para a interação PPI. Ainda, outra pergunta seria: "qual a probabilidade da interação $P-A$ " dado que há uma informação PPI e a ECM de $P-A$ é 0.2 , por exemplo? O modelo que está em desenvolvimento segue este raciocínio e a visão geral é apresentada a seguir.

\subsubsection{Visão geral do modelo}

Assuma que são dadas $n$ hipóteses e que estas sejam necessariamente exaustivas e mutuamente exclusivas. Por exemplo: dado um gene alvo e um preditor as hipóteses são: (a) existe uma aresta $P-A$ e (b) não existe uma aresta $P-A$. Ainda, dados dois preditores candidatos e um gene alvo as hipóteses são: (a) não há arestas preditores alvo, (b) há uma aresta preditores-alvo, (c) há duas arestas preditores-alvo. 
Assuma um conjunto de evidências a respeito da relação entre $P$ e $A$. Assuma também que há graus de manifestação da evidência. Por exemplo: evidência: interação PPI entre $P$ e $A$ obtido por Y2H. Graus de manifestação: baixa $(0 \leq p p i<0.3)$, média $(0.3 \leq p p i<0.7)$, alta $(0.7 \leq p p i \leq 1)$.

Assim, seja $e_{j}^{k}, k=1 \ldots n, j=1 \ldots l_{k}$ a k-ésima evidência com a j-ésima manifestação. Calcula-se a chance (odds) da hipótese $H$ dada a evidência $e_{j}^{k}$ da seguinte forma:

$$
\begin{gathered}
L_{j}^{k}=L\left(e_{j}^{k} \mid H\right)=\frac{P\left(e_{j}^{k} \mid H\right)}{P\left(e_{j}^{k} \mid H^{\prime}\right)}, \text { assim } \\
O\left(H \mid e_{j}^{k}\right)=L_{j}^{k} \cdot O(H),
\end{gathered}
$$

onde $L_{j}^{k}$ é a razão de verossimilhança da evidência $e_{j}^{k}$ dadas as hipótese $H$. e $O(H)$ é a chance de $H$.

A probabilidade da hipótese pode ser informada por um especialista ou estimada de uma rede gold standard. A probabilidade da evidência dada a hipótese pode ser estimada a partir da rede gabarito e do dado biológico. Por exemplo, para cada aresta existente na rede gabarito (Hipótese 1) é possível contar a proporção que compartilha o mesmo termo GO na profundidade 16: $P(G O=$ 16|H1). Assim, estes valores podem ser fornecidos por um especialista ou estimados a partir dos dados. O que deseja-se, porém, é calcular $P(H 1 \mid G O=16)$.

Deste modo, observando $n$ evidências queremos calcular a chance de cada hipótese dadas as evidências:

$$
O\left(H \mid e^{1} \cap e^{2} \cdots \cap e^{n}\right)=L\left(e^{1} \cap e^{2} \cdots \cap e^{n} \mid H\right) \cdot O(H)
$$

Ao observar a evidência $e^{1}$ temos $O\left(H \mid e^{1}\right)=L\left(e^{1} \mid H\right) \cdot O(H)$. Se $e^{1}$ e $e^{2}$ forem independentes podemos calcular:

$$
O\left(H \mid e^{1} \cap e^{2}\right)=L\left(e^{2} \mid H\right) O\left(H \mid e^{1}\right)=L\left(e^{2} \mid H\right) L\left(e^{1} \mid H\right) O(H),
$$

ou seja, ao observar $e^{1}$ a chance de $H, O(H)$, é reajustada. Desta forma, a chance de $H$ será $O\left(H \mid e^{1}\right)$ quando a segunda evidência for observada. Portanto a chance da hipótese dadas as evidências será:

$$
O\left(H \mid e^{1} \cap e^{2} \cdots \cap e^{n}\right)=\prod_{k=1}^{n}\left[L\left(e^{k} \mid H\right)\right] O(H)
$$

Considerando que são dadas $m$ hipóteses $H_{1}, H_{2}, \ldots, H_{m}$ associadas ao conjunto de $n$ evidências queremos calcular a $P\left(H_{i} \mid e_{j}^{k}\right)$ para todo $i=1, \ldots, n$.

Seja $\lambda_{j}^{i, k}=P\left(e_{j}^{k} \mid H_{i}\right)$ e seja o vetor da k-ésima evidência e j-ésima manifestação de cada hipótese dado por:

$$
\Lambda_{j}^{k}=\left[\begin{array}{c}
\lambda_{j}^{1, k} \\
\lambda_{j}^{2, k} \\
\vdots \\
\lambda_{j}^{m, k}
\end{array}\right]
$$

Seja $\tilde{P}(H)=\left[P\left(H_{1}\right), P\left(H_{2}\right), \ldots, P\left(H_{m}\right)\right]$ o vetor de suspeita a priori. Assim, pode-se calcular a 
probabilidade de cada hipótese dada e evidência $e_{j}^{k}$ :

$$
\tilde{P}\left(H \mid e_{j}^{k}\right)=\Lambda_{j}^{k} \cdot \tilde{P}(H) \times P\left(e_{j}^{k}\right)^{-} 1
$$

Desta forma, considerando hipóteses mutuamente exclusivas e exaustivas, a probabilidade de cada hipótese dadas múltiplas evidências é calculada aplicando-se o exposto acima, atualizando $P(H)$ atribuindo-lhe o valor de $P\left(H \mid e_{j}^{k}\right)$ para cada novo $\Lambda_{j}^{k}$ observado.

Neste novo algoritmo, a função critério é calculada da seguinte maneira:

$$
\underset{i}{\arg \max }\left\{O\left(H_{i} \mid e^{1} \cap e^{2} \cdots \cap e^{n}\right)\right\}
$$

Onde o valor da MCE é incluída como mais uma evidência. Uma vantagem deste método é que outras medidas extraídas dos dados de expressão podem ser incluídas assim como informações binárias (manifestação da evidência: presente/ausente) e informações quantitativas ordinais (manifestação da evidência: baixa, média, alta).

Um problema que ainda está sendo investigado é o algoritmo de busca e inclusão da informação topológica. A idéia é extrair a informação topológica diretamente de um grafo gold standard e utilizá-lo como probabilidade a priori da hipótese. Em outras palavras, dada uma cardinalidade máxima $k_{\max }$ para o número de preditores, estimar a partir do grafo gabarito a probabilidade de o alvo ter $1,2, \ldots, k_{\max }$ arestas. Isto é, $P(H 1), P(H 2), \ldots, P\left(k_{\max }\right)$. Deste modo, o algoritmo resolveria uma classe de problemas, independente de uma topologia específica.

\subsection{Considerações finais}

Os trabalhos de integração de dados mostraram potencial das metodologias para melhorar a inferência de redes gênicas. Os resultados sugerem que informação física direta tem potencial maior que informações qualitativas mais gerais como função gênica. Isto sugere que as informações talvez possam ser agrupadas por categoria (e.g. física versus funcional, qualitativa versus quantitativa, etc.). Além disto, os resultados também apontam para melhoria na precisão da rede inferida quando a informação topológica é utilizada. Durante a elaboração dos algoritmos, implementações dos métodos e realização dos experimentos diversas questões foram levantadas e novos problemas identificados, alguns deles reportados como trabalhos futuros. 


\section{Capítulo 6}

\section{Artigos publicados}

\section{GENSIPS 2011}

Vicente et al.(2011) - Fabio F. R. Vicente, Fabricio M. Lopes e Ronaldo F. Hashimoto. Improvement of GNs inference through biological data integration. Em Genomic Signal Processing and Statistics (GENSIPS), 2011 IEEE International Workshop on, paginas 70-73. IEEE Signal Proc Soc, IEEE. doi: 10.1109GENSiPS.2011.6169446.

\section{BMC GENOMICS 2012}

Vicente et al.(2012) - Fabio F. R. Vicente, Fabricio M. Lopes, Ronaldo F. Hashimoto e Roberto M. Cesar-Jr. Assessing the gain of biological data integration in gene networks inference. BMC Genomics, 13(Suppl 6):S7. ISSN 1471-2164. doi: 10.11861471-2164-13-S6-S7.

\section{PRIB 2014}

Vicente e Lopes(2014) - Fabio F. R. Vicente e Fabricio M. Lopes. SFFS-SW: A Feature Selection Algorithm Exploring the Small-World Properties of GNs. Em Pattern Recognition in Bioinformatics, Volume 8626 do LNCS, páginas 60-71. Springer International Publishing. ISBN 9783319091914. doi: 10.1007978-3-319-09192-1_6.

\section{CIARP 2015}

Vicente et al.(2015) - Fabio F. R. Vicente, Euler Menezes, Gabriel Rubino, Juliana Oliveira e Fabricio Martins Lopes. Feature Selection Approach for Evaluate the Inference of GRNs Through Biological Data Integration - A Case Study on A. Thaliana. Em Progress in Pattern Recognition, Image Analysis, Computer Vision, and Applications, Volume 9423 do LNCS, páginas 667-675. Springer International Publishing. ISBN 9783319257501. doi: 10.1007978-3-319-25751-8_80. 


\section{Referências Bibliográficas}

Aittokallio e Schwikowski(2006) Tero Aittokallio e Benno Schwikowski. Graph-based methods for analysing networks in cell biology. Briefings in Bioinformatics, 7(3):243-255. doi: 10.1093/ bib/bbl022. Citado na pág. 26

Albert(2005) Réka Albert. Scale-free networks in cell biology. J Cell Sci, 118(21):4947-4957. doi: $10.1242 /$ jcs.02714. Citado na pág. 4

Albert e Barabási(2002) Réka Albert e Albert-Laszlo Barabási. Statistical mechanics of complex networks. Rev. Mod. Phys., 74(1):47-97. doi: 10.1103/RevModPhys.74.47. Citado na pág. 23, 25, 36

Amaral et al.(2000) L. A. N. Amaral, A. Scala, Barthélémy M. e H.E. Stanley. Classes of smallworld networks. Proceedings of the National Academy of Sciences of the United States of America, 97(21):11149-52. ISSN 0027-8424. doi: 10.1073/pnas.200327197. Citado na pág. 24

Ashburner et al.(2000) Michael Ashburner, Catherine A Ball, Judith A Blake, David Botstein, Heather Butler, J Michael Cherry, Allan P Davis, Kara Dolinski, Selina S Dwight, Janan T Eppig, Midori A Harris, David P Hill, Laurie Issel-Tarver, Andrew Kasarskis, Suzanna Lewis, John C Matese, Joel E Richardson, Martin Ringwald, Gerald M Rubin e Gavin Sherlock. Gene Ontology: tool for the unification of biology. Nat Genet, 25(1):25-29. ISSN 1061-4036. Citado na pág. 10

Assenov et al.(2008) Yassen Assenov et al. Computing topological parameters of biological networks. Bioinformatics (Oxford, England), 24(2):282-4. ISSN 1367-4811. doi: 10.1093/ bioinformatics/btm554. Citado na pág. 25

Baek et al.(2012) Woon Hak Baek et al. Analysis of topological properties in a seismic network. Physica A: Statistical Mechanics and its Applications, 391(6):2279-2285. ISSN 03784371. doi: 10.1016/j.physa.2011.11.047. Citado na pág. 23, 25

Baitaluk et al.(2010) Michael Baitaluk et al. Semantic integration of data on transcriptional regulation. Bioinformatics (Oxford, England), 26(13):1651-61. ISSN 1367-4811. doi: 10.1093/ bioinformatics/btq231. Citado na pág. 26, 28

Bansal et al.(2007) Mukesh Bansal, Vincenzo Belcastro, Alberto Ambesi-Impiombato e Diego di Bernardo. How to infer gene networks from expression profiles. Molecular Systems Biology, 3 (1). ISSN 1744-4292. doi: 10.1038/msb4100120. Citado na pág. 1

Barabási(2009) Albert-Laszlo Barabási. Scale-Free Networks: A Decade and Beyond. Science, 325(5939):412-413. doi: 10.1126/science.1173299. Citado na pág. 4 
Barabási et al.(2011) Albert-Laszlo Barabási, Natali Gulbahce e Joseph Loscalzo. Network medicine: a network-based approach to human disease. Nat Rev Genet, 12(1):56-68. ISSN 1471-0056. doi: 10.1038/nrg2918. Citado na pág. 1, 7, 45

Baralla et al.(2009) Angela Baralla, Wieslawa I Mentzen e Alberto de la Fuente. Inferring gene networks: dream or nightmare? Annals of the New York Academy of Sciences, 1158:246-56. ISSN 1749-6632. doi: 10.1111/j.1749-6632.2008.04099.x. Citado na pág. 1, 19

Barrat e Weigt(1999) A Barrat e M Weigt. On the properties of small-world network models. The European Physical Journal B-Condensed Matter ..., 560:19. Citado na pág. 5

Barrera et al.(2004) J. Barrera, R.M. Cesar Jr., D.C. Martins Jr., E.F. Merino, R.Z.N. Vêncio, F.G. Leonardi, M.M. Yamamoto, C.A.B. Pereira e H.A. del Portillo. A new annotation tool for malaria based on inference of probabilistic genetic networks. Em Fifth International Conference for the Critical Assessment of Microarray Data Analysis (CAMDA 2004), páginas 18-19, Durham. Citado na pág. $16,32,55$

Barrera et al.(2007) Junior Barrera, Jr. Cesar, Roberto M., Jr. Martins, David C., Ricardo Z.N. Vêncio, Emilio F. Merino, Márcio M. Yamamoto, Florencia G. Leonardi, Carlos A. de B. Pereira e Hernando A. Portillo. Constructing Probabilistic Genetic Networks of Plasmodium falciparum from Dynamical Expression Signals of the Intraerythrocytic Development Cycle. Citado na pág. 16

Barrett et al.(2013) Tanya Barrett, Stephen E. Wilhite, Pierre Ledoux, Carlos Evangelista, Irene F. Kim, Maxim Tomashevsky, Kimberly a. Marshall, Katherine H. Phillippy, Patti M. Sherman, Michelle Holko, Andrey Yefanov, Hyeseung Lee, Naigong Zhang, Cynthia L. Robertson, Nadezhda Serova, Sean Davis e Alexandra Soboleva. NCBI GEO: Archive for functional genomics data sets - Update. NAR, 41(D1):991-995. ISSN 03051048. doi: 10.1093/nar/gks1193. Citado na pág. 40

Bassett e Bullmore(2006) Danielle Smith Bassett e Ed Bullmore. Small-world brain networks. The Neuroscientist : a review journal bringing neurobiology, neurology and psychiatry, 12(6): 512-23. ISSN 1073-8584. doi: 10.1177/1073858406293182. Citado na pág. 23, 25

Baumbach et al.(2009) Jan Baumbach, Andreas Tauch e Sven Rahmann. Towards the integrated analysis, visualization and reconstruction of microbial gene regulatory networks. Brief Bioinform, 10(1):75-83. doi: 10.1093/bib/bbn055. Citado na pág. 26

Benson et al.(2008) Dennis A. Benson, Ilene Karsch-Mizrachi, David J. Lipman, James Ostell e David L. Wheeler. GenBank. Nucleic Acids Research, 36(suppl 1):D25-D30. doi: 10.1093/nar/ gkm929. Citado na pág. 26

Bhardwaj et al.(2005) Nitin Bhardwaj et al. Correlation between generations expression profiles and protein-protein interactions within and across genomes. Bioinformatics (Oxford, England), 21(11):2730-8. ISSN 1367-4803. doi: 10.1093/bioinformatics/bti398. Citado na pág. 28

Bishop(2006) Christopher M. Bishop. Pattern Recognition and Machine Learning. Springer-Verlag New York, Inc., Secaucus, NJ, USA. ISBN 0387310738. Citado na pág. 17, 18, 22 
Boltzmann(1974) Ludwig Boltzmann. Theoretical Physics and Philosophical Problems: Selected Writings. Springer. ISBN 978-90-277-0250-0 (Print). Citado na pág. 21

Bozdech et al.(2003) Zbynek Bozdech, Manuel Llinás, Brian Lee Paulliam, D. Edith Wong, J. Zhu e Joseph L. DeRisi. The transcriptome of the intraerythrocytic developmental cycle of Plasmodium falciparum. PLoS biology, 1(1):E5. ISSN 1545-7885. doi: 10.1371/journal.pbio.0000005. Citado na pág. 32,55

Brockmann e Helbing(2013) D. Brockmann e D. Helbing. The Hidden Geometry of Complex, Network-Driven Contagion Phenomena. Science, 342(6164):1337-1342. ISSN 0036-8075. doi: 10.1126/science.1245200. Citado na pág. 24, 36

Carroll et al.(2004) S. B. Carroll, J. K. Grenier e S. D. Weatherbee. From DNA to diversity: molecular genetics and the evolution of animal design. Wiley-Blackwell, 2nd edição. Citado na pág. 4

Childs et al.(2007) Kevin L. Childs, John P. Hamilton, Wei Zhu, Eugene Ly, Foo Cheung, Hank Wu, Pablo D. Rabinowicz, Chris D. Town, C. Robin Buell e Agnes P. Chan. The tigr plant transcript assemblies database. Nucleic Acids Research, 35(suppl 1):D846-D851. doi: 10.1093/ nar/gkl785. Citado na pág. 40

Clausius(1879) R. Clausius. The Mechanical Theory of Heat. Cambridge University Press, London. Citado na pág. 21

Costa et al.(2007a) L. da F. Costa, F. A. Rodrigues, G. Travieso e P. R. Villas-Boas. Characterization of complex networks: a survey of measurements. Advances in Physics, 56(1):167-242. doi: 10.1080/00018730601170527. Citado na pág. xviii, 24, 50

Costa et al.(2008) L. da F. Costa, F. A. Rodrigues e A. S. Cristino. Complex networks: the key to systems biology. Genetics and Molecular Biology, 31(3):591-601. ISSN 1415-4757. doi: 10.1590/S1415-47572008000400001. Citado na pág. 4

Costa et al.(2007b) L. da F. Costa et al. Characterization of complex networks: a survey of measurements. Advances in Physics, 56(1):167-242. doi: 10.1080/00018730601170527. Citado na pág. 25

Cui et al.(2010) Xiaoqi Cui, Tong Wang, Huann-Sheng Chen, Victor Busov e Hairong Wei. Tffinder: A software package for identifying transcription factors involved in biological processes using microarray data and existing knowledge base. BMC Bioinformatics, 11(1):425. ISSN 14712105. doi: 10.1186/1471-2105-11-425. Citado na pág. 26

Date e Stoeckert(2006) Shailesh V Date e Christian J Stoeckert. Computational modeling of the Plasmodium falciparum interactome reveals protein function on a genome-wide scale. Genome research, 16(4):542-9. ISSN 1088-9051. doi: 10.1101/gr.4573206. Citado na pág. 33, 34

Davis e Meltzer(2007) Sean Davis e Paul Meltzer. Geoquery: a bridge between the gene expression omnibus (geo) and bioconductor. Bioinformatics, 14:1846-1847. Citado na pág. 41 
De Bodt et al.(2009) Stefanie De Bodt et al. Predicting protein-protein interactions in Arabidopsis thaliana through integration of orthology, gene ontology and co-expression. BMC genomics, 10: 288. ISSN 1471-2164. doi: 10.1186/1471-2164-10-288. Citado na pág. 1, 7

De Haan et al.(2010) Jorn De Haan, Ester Piek, Rene van Schaik, Jacob de Vlieg, Susanne Bauerschmidt, Lutgarde Buydens e Ron Wehrens. Integrating gene expression and go classification for pca by preclustering. BMC Bioinformatics, 11(1):158. ISSN 1471-2105. doi: 10.1186/1471-2105-11-158. Citado na pág. 26

de la Fuente et al.(2004) Alberto de la Fuente, Nan Bing, Ina Hoeschele e Pedro Mendes. Discovery of meaningful associations in genomic data using partial correlation coefficients. Bioinformatics, 20(18):3565-3574. ISSN 1367-4803. doi: 10.1093/bioinformatics/bth445. Citado na pág. 21

D'haeseleer et al.(2000) P D'haeseleer et al. Genetic network inference: from co-expression clustering to reverse engineering. Bioinformatics (Oxford, England), 16(8):707-26. ISSN 13674803. Citado na pág. 8,20

Dougherty(2007) E. R. Dougherty. Validation of inference procedures for gene regulatory networks. Current Genomics, 8(6):351-359. ISSN 1389-2029. doi: 10.2174/138920207783406505. Citado na pág. 25, 35, 36, 50

Dougherty e Bittner(2010) Edward R Dougherty e Michael L Bittner. Causality, randomness, intelligibility, and the epistemology of the cell. Current genomics, 11(4):221-37. ISSN 1875-5488. doi: 10.2174/138920210791233072. Citado na pág. 19, 23, 25, 36

Duda et al.(2000) Richard O. Duda, Peter E. Hart e David G. Stork. Pattern Classification (2Nd Edition). Wiley-Interscience. ISBN 0471056693. Citado na pág. xviii, 17, 18

Easley e Kleinberg(2012) David Easley e Jon Kleinberg. Networks, Crowds, and Markets: Reasoning about a Highly Connected World. Cambridge University Press. ISBN 978-0-521-195331. Citado na pág. 23, 24

Edgar et al.(2002) Ron Edgar, Michael Domrachev e Alex E Lash. Gene Expression Omnibus: NCBI gene expression and hybridization array data repository. Nucleic acids research, 30(1): 207-210. ISSN 1362-4962. doi: 10.1093/nar/30.1.207. Citado na pág. 41

Ernst et al.(2008) Jason Ernst, Qasim K. Beg, Krin A. Kay, Gábor Balázsi, Zoltán N. Oltvai e Ziv Bar-Joseph. A semi-supervised method for predicting transcription factor-gene interactions in Escherichia coli. PLoS Comput Biol, 4(3):e1000044. doi: 10.1371/journal.pcbi.1000044. Citado na pág. 26

Fromont-Racine et al.(1997) Micheline Fromont-Racine, Jean-Christophe Rain e Pierre Legrain. Toward a functional analysis of the yeast genome through exhaustive two-hybrid screens. Nature Genetics, 16(3):277-282. ISSN 1061-4036. doi: 10.1038/ng0797-277. Citado na pág. 8

Gentleman et al.(2004) Robert C Gentleman, Vincent J Carey, Douglas M Bates, Ben Bolstad, Marcel Dettling, Sandrine Dudoit, Byron Ellis, Laurent Gautier, Yongchao Ge, Jeff Gentry, Kurt Hornik, Torsten Hothorn, Wolfgang Huber, Stefano Iacus, Rafael Irizarry, Friedrich Leisch, 
Cheng Li, Martin Maechler, Anthony J Rossini, Gunther Sawitzki, Colin Smith, Gordon Smyth, Luke Tierney, Jean Y H Yang e Jianhua Zhang. Bioconductor: open software development for computational biology and bioinformatics. Genome biology, 5(10):R80. ISSN 1465-6914. doi: 10.1186/gb-2004-5-10-r80. Citado na pág. 41

Ghaffari et al.(2010) Noushin Ghaffari, Ivan Ivanov, Xiaoning Qian e Edward R. Dougherty. A CoD-based reduction algorithm for designing stationary control policies on Boolean networks. Bioinformatics, 26(12):1556-1563. ISSN 1367-4803. doi: 10.1093/bioinformatics/btq225. Citado na pág. 21

Giot et al.(2003) L. Giot, J. S. Bader, C. Brouwer, A. Chaudhuri, B. Kuang, Y. Li, Y. L. Hao, C. E. Ooi, B. Godwin, E. Vitols, G. Vijayadamodar, P. Pochart, H. Machineni, M. Welsh, Y. Kong, B. Zerhusen, R. Malcolm, Z. Varrone, A. Collis, M. Minto, S. Burgess, L. McDaniel, E. Stimpson, F. Spriggs, J. Williams, K. Neurath, N. Ioime, M. Agee, E. Voss, K. Furtak, R. Renzulli, N. Aanensen, S. Carrolla, E. Bickelhaupt, Y. Lazovatsky, A. DaSilva, J. Zhong, C. A. Stanyon, R. L. Finley, K. P. White, M. Braverman, T. Jarvie, S. Gold, M. Leach, J. Knight, R. A. Shimkets, M. P. McKenna, J. Chant e J. M. Rothberg. A protein interaction map of drosophila melanogaster. Science, 302(5651):1727-1736. ISSN 0036-8075. doi: 10.1126/science.1090289. Citado na pág. 8

Gray(1990) R.M. Gray. Entropy and Information Theory. Number 1. Springer. Citado na pág. 23

Harris et al.(2004) M A Harris et al. The Gene Ontology (GO) database and informatics resource. NAR, 32(Database issue):D258-61. ISSN 1362-4962. doi: 10.1093/nar/gkh036. Citado na pág. 3, 26,40

Hashimoto et al.(2004) Ronaldo F. Hashimoto, Seungchan Kim, Ilya Shmulevich, Wei Zhang, Michael L. Bittner e Edward R. Dougherty. Growing genetic regulatory networks from seed genes. Bioinformatics, 20(8):1241-1247. ISSN 1367-4803. doi: 10.1093/bioinformatics/bth074. Citado na pág. 21

Hecker et al.(2009) Michael Hecker et al. Gene regulatory network inference: data integration in dynamic models-a review. Bio Systems, 96(1):86-103. ISSN 1872-8324. doi: 10.1016/j.biosystems. 2008.12.004. Citado na pág. 3, 26, 28

Hu et al.(2009) Guangan Hu, Ana Cabrera, Maya Kono, Sachel Mok, B.K. Chaal, Silvia Haase, Klemens Engelberg, Sabna Cheemadan, Tobias Spielmann, P.R. Preiser e Others. Transcriptional profiling of growth perturbations of the human malaria parasite Plasmodium falciparum. Nature biotechnology, 28(1):91-98. ISSN 1087-0156. doi: 10.1038/nbt.1597. Citado na pág. 34

Huber et al.(2015) Wolfgang Huber, Vincent J Carey, Robert Gentleman, Simon Anders, Marc Carlson, Benilton S Carvalho, Hector Corrada Bravo, Sean Davis, Laurent Gatto, Thomas Girke, Raphael Gottardo, Florian Hahne, Kasper D Hansen, Rafael A Irizarry, Michael Lawrence, Michael I Love, James Macdonald, Valerie Obenchain, Andrzej K Oleś, Hervé Pagès, Alejandro Reyes, Paul Shannon, Gordon K Smyth, Dan Tenenbaum, Levi Waldron e Martin Morgan. Orchestrating high-throughput genomic analysis with Bioconductor. Nature Publishing Group, 12 (2):115-121. ISSN 1548-7091. doi: 10.1038/nmeth.3252. Citado na pág. 41 
Ito et al.(2001) T Ito et al. A comprehensive two-hybrid analysis to explore the yeast protein interactome. PNAS, 98(8):4569-74. ISSN 0027-8424. doi: 10.1073/pnas.061034498. Citado na pág. 26

Jain et al.(2000) A. K. Jain, R. P. W. Duin e J. Mao. Statistical pattern recognition: A review. IEEE TPAMI, 22(1):4-37. Citado na pág. 2, 18

Jansen(2002) Ronald Jansen. Relating Whole-Genome Expression Data with Protein-Protein Interactions. Genome Research, 12(1):37-46. ISSN 10889051. doi: 10.1101/gr.205602. Citado na pág. 9

Jeong et al.(2000) H. Jeong, B. Tombor, R. Albert, Z. N. Oltvai e Albert-Laszlo Barabási. The large-scale organization of metabolic networks. Nature, 407:651-654. Citado na pág. 25

Johnson et al.(2007) David S Johnson, Ali Mortazavi, Richard M Myers e Barbara Wold. Genomewide mapping of in vivo protein-DNA interactions. Science (New York, N.Y.), 316(5830):1497502. ISSN 1095-9203. doi: 10.1126/science.1141319. Citado na pág. 26

Kaleta et al.(2010) Christoph Kaleta, Anna Gohler, Stefan Schuster, Knut Jahreis, Reinhard Guthke e Swetlana Nikolajewa. Integrative inference of gene-regulatory networks in escherichia coli using information theoretic concepts and sequence analysis. BMC Systems Biology, 4(1):116. ISSN 1752-0509. doi: 10.1186/1752-0509-4-116. Citado na pág. 26

Kanehisa(2000) M. Kanehisa. KEGG: Kyoto Encyclopedia of Genes and Genomes. NAR, 28(1): 27-30. ISSN 13624962. doi: 10.1093/nar/28.1.27. Citado na pág. 9, 26, 34

Kanehisa et al.(2010) Minoru Kanehisa et al. KEGG for representation and analysis of molecular networks involving diseases and drugs. NAR, 38(Database issue):D355-D360. Citado na pág. 28

Karlebach e Shamir(2008) Guy Karlebach e Ron Shamir. Modelling and analysis of gene regulatory networks. Nat Rev Mol Cell Biol, 9(10):770780. doi: 10.1038/nrm2503. Citado na pág. 19,26

Kauffman(1969) Stuart A. Kauffman. Metabolic stability and epigenesis in randomly constructed genetic nets. Journal of Theoretical Biology, 22(3):437-467. doi: 10.1016/0022-5193(69)90015-0. Citado na pág. 12

LaCount et al.(2005) Douglas J LaCount et al. A protein interaction network of the malaria parasite Plasmodium falciparum. Nature, 438(7064):103-7. ISSN 1476-4687. doi: 10.1038/nature04104. Citado na pág. 26, 28, 32, 33

Lago-Fernández et al.(2000) Lago-Fernández et al. Fast response and temporal coherent oscillations in small-world networks. Physical review letters, 84(12):2758-61. ISSN 0031-9007. Citado na pág. 23, 24, 25

Lamesch et al.(2011) Philippe Lamesch, Tanya Z. Berardini, Donghui Li, David Swarbreck, Christopher Wilks, Rajkumar Sasidharan, Robert Muller, Kate Dreher, Debbie L. Alexander, Margarita Garcia-Hernandez, Athikkattuvalasu S. Karthikeyan, Cynthia H. Lee, William D. Nelson, Larry Ploetz, Shanker Singh, April Wensel e Eva Huala. The arabidopsis information resource 
(TAIR): improved gene annotation and new tools. NAR. doi: 10.1093/nar/gkr1090. Citado na pág. 40,55

Latora e Marchiori(2001) Vito Latora e Massimo Marchiori. Efficient Behavior of Small-World Networks. Physical Review Letters, 87(19):198701. ISSN 0031-9007. doi: 10.1103/PhysRevLett. 87.198701. Citado na pág. 23

Latora e Marchiori(2002) Vito Latora e Massimo Marchiori. Is the Boston subway a smallworld network? Physica A: Statistical Mechanics and its Applications, 314(1-4):109-113. ISSN 03784371. doi: 10.1016/S0378-4371(02)01089-0. Citado na pág. 23, 25

Li et al.(2004) Fangting Li, Tao Long, Ying Lu, Qi Ouyang e Chao Tang. The yeast cell-cycle network is robustly designed. Proceedings of the National Academy of Sciences of the United States of America, 101(14):4781-4786. ISSN 0027-8424. doi: 10.1073/pnas.0305937101. Citado na pág. 14

Liang et al.(1998) Shoudan Liang, Stefanie Fuhrman e Roland Somogyi. Reveal, a general reverse engineering algorithm for inference of genetic network architectures. Em Pacific Symposium on Biocomputing. Citado na pág. 23

Lodish et al.(2000) H Lodish et al. Genetic network inference: from co-expression clustering to reverse engineering. Bioinformatics (Oxford, England), 16(8):707-26. ISSN 1367-4803. Citado na pág. 8

Lopes et al.(2008a) F. M. Lopes, D. C. Martins-Jr e R. M. Cesar-Jr. DimReduction - interactive graphic environment for dimensionality reduction. Relatório técnico, Instituto de Matemática e Estatística da Universidade de São Paulo and Universidade Tecnológica Federal do Paraná. Citado na pág. 5

Lopes(2011) Fabrício M. Lopes. Redes complexas de expressão gênica: sintese, identificação, análise e aplicações. Tese de Doutorado, Bioinformática, Universidade de São Paulo, São Paulo. URL http://www.teses.usp.br/teses/disponiveis/95/95131/tde-27072011-105810/. Citado na pág. 12

Lopes et al.(2008b) Fabrício M. Lopes, Roberto M. Cesar-Jr e Luciano da F. Costa. AGN simulation and validation model. Em Advances in Bioinformatics and Computational Biology, Proceedings, volume 5167 of Lecture Notes in Bioinformatics, páginas 169-173. Springer-Verlag Berlin. ISBN 978-3-540-85556-9. doi: 10.1007/978-3-540-85557-6\_17. Citado na pág. 36, 39

Lopes et al.(2008c) Fabrício M. Lopes, David C. Martins-Jr e Roberto M. Cesar-Jr. Feature selection environment for genomic applications. BMC Bioinformatics, 9(1):451. ISSN 1471-2105. doi: 10.1186/1471-2105-9-451. Citado na pág. 5, 20, 22, 23, 30

Lopes et al.(2010) Fabrício M. Lopes, David C. Martins-Jr, Junior Barrera e Roberto M. Cesar-Jr. SFFS-MR: a floating search strategy for GRNs inference. Em Pattern Recognition in Bioinformatics, Proceedings, volume 6282 of Lecture Notes in Computer Science, páginas 407-418. Springer Berlin / Heidelberg. ISBN 9783642160004. doi: 10.1007/978-3-642-16001-1 \_35. 5th IAPR International Conference on Pattern Recognition in Bioinformatics (PRIB 2010), Nijmegen, The Netherlands, SEP 22-24, 2010. Citado na pág. 5, 20 
Lopes et al.(2011) Fabrício M. Lopes, Roberto M. Cesar-Jr e Luciano da Fontoura Costa. Gene expression complex networks: Synthesis, identification, and analysis. Journal of Computational Biology, 18(10):1353-1367. ISSN 1066-5277. doi: 10.1089/cmb.2010.0118. Citado na pág. 5, 20, 36, 39

Lopes et al.(2014a) Fabrício M. Lopes, David C. Martins Jr., Junior Barrera e Roberto M. Cesar Jr. A feature selection technique for inference of graphs from their known topological properties: Revealing scale-free gene regulatory networks. Information Sciences, 272(0):1-15. ISSN 00200255. doi: http://dx.doi.org/10.1016/j.ins.2014.02.096". Citado na pág. 3, 26

Lopes et al.(2014b) Fabrício M. Lopes, Shubhra Sankar Ray, Ronaldo F. Hashimoto e Roberto M. Cesar Jr. Entropic biological score: a cell cycle investigation for GRNs inference. Gene, 541 (2):129-137. ISSN 0378-1119. doi: http://dx.doi.org/10.1016/j.gene.2014.03.010. Citado na pág. 3, 19

Lu et al.(2005) Long $\mathrm{J} \mathrm{Lu}$ et al. Assessing the limits of genomic data integration for predicting protein networks. Genome research, 15(7):945-53. ISSN 1088-9051. doi: 10.1101/gr.3610305. Citado na pág. 1, 7, 28

Ma et al.(2004) Hong-Wu Ma et al. Hierarchical structure and modules in the Escherichia coli transcriptional regulatory network revealed by a new top-down approach. BMC bioinformatics, 5:199. ISSN 1471-2105. doi: 10.1186/1471-2105-5-199. Citado na pág. 25

Macintyre et al.(2010) Geoff Macintyre, James Bailey, Daniel Gustafsson, Izhak Haviv e Adam Kowalczyk. Using gene ontology annotations in exploratory microarray clustering to understand cancer etiology. Pattern Recognition Letters, 31(14):2138-2146. ISSN 0167-8655. doi: 10.1016/j. patrec.2010.01.006. Citado na pág. 26

Mangan e Alon(2003) S. Mangan e U. Alon. Structure and function of the feed-forward loop network motif. 100(21):11980-11985. doi: 10.1073/pnas.2133841100. Citado na pág. 11

Marbach et al.(2012) Daniel Marbach, James C Costello, Robert Küffner, Nicole M Vega, Robert J Prill, Diogo M Camacho, Kyle R Allison, Manolis Kellis, James J Collins, Gustavo Stolovitzky et al. Wisdom of crowds for robust gene network inference. Nature methods, 9(8):796-804. Citado na pág. 26

Marcotte(1999) E. M. Marcotte. Detecting Protein Function and Protein-Protein Interactions from Genome Sequences. Science, 285(5428):751-753. ISSN 00368075. doi: 10.1126/science.285. 5428.751. Citado na pág. 10, 27, 33

Marshall et al.(2007) Stephen Marshall, Le Yu, Yufei Xiao e Edward R. Dougherty. Inference of a probabilistic boolean network from a single observed temporal sequence. EURASIP Journal on Bioinformatics and Systems Biology, 2007(1):1-15. ISSN 1687-4153. doi: 10.1155/2007/32454. Citado na pág. 1

Milgram(1967) Stanley Milgram. The Small-World Problem. Psychology Today, 1(1):61-67. Citado na pág. 25 
Moore e Newman(2000) C Moore e M E Newman. Epidemics and percolation in small-world networks. Physical review. E, Statistical physics, plasmas, fluids, and related interdisciplinary topics, 61(5 Pt B):5678-82. ISSN 1063-651X. Citado na pág. 25

Newman e Watts(1999) M E Newman e D J Watts. Scaling and percolation in the small-world network model. Physical review. E, Statistical physics, plasmas, fluids, and related interdisciplinary topics, 60(6 Pt B):7332-42. ISSN 1063-651X. Citado na pág. 25

Pavlopoulos et al.(2011) Georgios a Pavlopoulos, Maria Secrier, Charalampos N Moschopoulos, Theodoros G Soldatos, Sophia Kossida, Jan Aerts, Reinhard Schneider e Pantelis G Bagos. Using graph theory to analyze biological networks. BioData Mining, 4(1):10. ISSN 1756-0381. doi: 10.1186/1756-0381-4-10. Citado na pág. 25

Pearl(1988) J. Pearl. Probabilistic reasoning in intelligent systems: networks of plausible inference. Morgan Kaufmann. Citado na pág. 59

Pellegrini(1999) M. Pellegrini. Assigning protein functions by comparative genome analysis: Protein phylogenetic profiles. PNAS, 96(8):4285-4288. ISSN 00278424. doi: 10.1073/pnas.96.8. 4285. Citado na pág. 27

Pudil et al.(1994) P. Pudil, J. Novovičová e J. Kittler. Floating search methods in feature-selection. Pattern Recognition Letters, 15(11):1119-1125. ISSN 0167-8655. doi: 10.1016/0167-8655(94) 90127-9. Citado na pág. 30, 31

Ravasz et al.(2002) E Ravasz et al. Hierarchical organization of modularity in metabolic networks. Science (New York, N.Y.), 297(5586):1551-5. ISSN 1095-9203. doi: 10.1126/science.1073374. Citado na pág. 25

Ray et al.(2009) Shubhra Sankar Ray et al. Combining multisource information through functional-annotation-based weighting: gene function prediction in yeast. IEEE transactions on bio-medical engineering, 56(2):229-36. ISSN 1558-2531. doi: 10.1109/TBME.2008.2005955. Citado na pág. 3, 27, 28

Rual et al.(2005) Jean-François Rual et al. Towards a proteome-scale map of the human protein-protein interaction network. Nature, 437(7062):1173-8. ISSN 1476-4687. doi: 10.1038/ nature04209. Citado na pág. 9, 26

Schena et al.(1995) M. Schena et al. Quantitative Monitoring of Gene Expression Patterns with a Complementary DNA Microarray. Science, 270(5235):467-470. ISSN 0036-8075. doi: 10.1126/ science.270.5235.467. Citado na pág. 8

Seok et al.(2010) Junhee Seok, Amit Kaushal, Ronald Davis e Wenzhong Xiao. Knowledgebased analysis of microarrays for the discovery of transcriptional regulation relationships. $B M C$ Bioinformatics, 11(Suppl 1):S8. ISSN 1471-2105. doi: 10.1186/1471-2105-11-S1-S8. Citado na pág. 26

Shannon e Weaver(1963) C. E. Shannon e W. Weaver. The mathematical theory of communication. University of Illinois Press. Citado na pág. 21 
Shmulevich e Dougherty(2007) I Shmulevich e E. R. Dougherty. Genomic Signal Processing. Princeton University Press, USA, 1st edição. ISBN 9781400865260. Citado na pág. 1

Shmulevich e Dougherty(2002) I. Shmulevich e E.R. Dougherty. From Boolean to probabilistic Boolean networks as models of genetic regulatory networks. Proceedings of the IEEE, 90(11): 1778-1792. ISSN 0018-9219. doi: 10.1109/JPROC.2002.804686. Citado na pág. 19, 23

Shmulevich et al.(2002a) I. Shmulevich, E. R. Dougherty, S. Kim e W. Zhang. Probabilistic boolean networks: a rule-based uncertainty model for gene regulatory networks. Bioinformatics, 18(2):261274. Citado na pág. 14

Shmulevich et al.(2002b) I. Shmulevich, E. R. Dougherty e W. Zhang. From Boolean to probabilistic Boolean networks as models of genetic regulatory networks. Proceedings of the IEEE, 90 (11):17781792. Citado na pág. 14

Somol et al.(1999) P. Somol, P. Pudil, J. Novovičová e P. Paclík. Adaptive floating search methods in feature selection. Pattern Recognition Letters, 20:1157-1163. doi: 10.1016/S0167-8655(99) 00083-5. Citado na pág. 30

Strachan et al.(1999) T Strachan et al. Human Molecular Genetics, volume 2. BIOS Scientific Oxford, 2nd edição. Citado na pág. 8

Strogatz(2001) S H Strogatz. Exploring complex networks. Nature, 410(6825):268-76. ISSN 0028-0836. doi: 10.1038/35065725. Citado na pág. 5, 25, 48

Stuart et al.(2003) J. M. Stuart, E. Segal, D. Koller e S. K. Kim. A gene-coexpression network for global discovery of conserved genetic modules. Science, 302(5643):249-255. doi: 10.1126/science. 1087447. Citado na pág. 4

Theodoridis e Koutroumbas(2008) S. Theodoridis e K. Koutroumbas. Pattern Recognition. Academic Press, USA, 4th edição. ISBN 1597492728. Citado na pág. 27

Troyanskaya(2005) Olga G. Troyanskaya. Putting microarrays in a context: Integrated analysis of diverse biological data. Brief Bioinform, 6(1):34-43. doi: 10.1093/bib/6.1.34. Citado na pág. 26

Tsallis(1988) Constantino Tsallis. Possible generalization of boltzmann-gibbs statistics. Journal of Statistical Physics, 52(1). doi: 10.1007/BF01016429. Citado na pág. 21

Vázquez et al.(2004) a Vázquez et al. The topological relationship between the large-scale attributes and local interaction patterns of complex networks. Proceedings of the National Academy of Sciences of the United States of America, 101(52):17940-5. ISSN 0027-8424. doi: 10.1073/pnas.0406024101. Citado na pág. 24

Veitia(2002) Reiner Veitia. Rosetta Stone proteins: chance and necessity ? Genome Biology, 3(2). ISSN 1465-6906. doi: 10.1186/gb-2002-3-2-interactions1001. Citado na pág. 27

Velculescu et al.(1995) Victor E. Velculescu, Lin Zhang, Bert Vogelstein e Kenneth W. Kinzler. Serial Analysis of Gene Expression. Science, 270(5235):484-487. doi: 10.1126/science.270.5235. 484. Citado na pág. 8 
Vicente e Lopes(2014) Fabio F. R. Vicente e Fabrício M. Lopes. SFFS-WS: A feature selection algorithm exploring the small-world properties of GNs. Em Pattern Recognition in Bioinformatics, Proceedings, volume 8626 of LNCS, páginas 60-71. Springer Berlin / Heidelberg. ISBN 9783319091914. Citado na pág. 5, 20, 36

Vicente et al.(2011) Fabio F. R. Vicente, Fabrício M. Lopes e Ronaldo F. Hashimoto. Improvement of GNs inference through biological data integration. Em Genomic Signal Processing and Statistics (GENSIPS), 2011 IEEE International Workshop on, páginas 70-73. IEEE Signal Proc Soc, IEEE. doi: 10.1109/GENSiPS.2011.6169446. Citado na pág. 3, 5, 42

Vicente et al.(2012) Fabio F. R. Vicente, Fabrício M. Lopes, Ronaldo F. Hashimoto e Roberto M. Cesar-Jr. Assessing the gain of biological data integration in gene networks inference. $B M C$ Genomics, 13(Suppl 6):S7. ISSN 1471-2164. doi: 10.1186/1471-2164-13-S6-S7. Citado na pág. 5, 42

Vicente et al.(2015) Fábio F. R. Vicente, Euler Menezes, Gabriel Rubino, Juliana Oliveira e Fabrício Martins Lopes. Feature Selection Approach for Evaluate the Inference of GRNs Through Biological Data Integration - A Case Study on A. Thaliana. Citado na pág. 5

Vicente(2006) Fábio FR Vicente. Heurística de regulação combinatória na recustroção de redes de genes. Dissertação de Mestrado, UFPE. Citado na pág. xvii, 9

Vidal(2005) Marc Vidal. Interactome modeling. FEBS Letters, 579(8):1834-1838. ISSN 00145793. doi: 10.1016/j.febslet.2005.02.030. Citado na pág. 26

Voet et al.(2005) D. Voet, J. Voet e C. W. Pratt. Fundamentals of Biochemistry: Life at the Molecular Level. John Wiley \& Sons, USA, 2nd edição. ISBN 0471214957. Citado na pág. 7

Walhout et al.(2000) Albertha J. M. Walhout, Raffaella Sordella, Xiaowei Lu, James L. Hartley, Gary F. Temple, Michael A. Brasch, Nicolas Thierry-Mieg e Marc Vidal. Protein interaction mapping in c. elegans using proteins involved in vulval development. Science, 287(5450):116-122. ISSN 0036-8075. doi: 10.1126/science.287.5450.116. Citado na pág. 8

Wang e Huang(2014) Y.X. Rachel Wang e Haiyan Huang. Review on statistical methods for gene network reconstruction using expression data. Journal of Theoretical Biology, 362(2014): 53-61. ISSN 00225193. doi: 10.1016/j.jtbi.2014.03.040. Citado na pág. 20

Wang et al.(2009) Zhong Wang, Mark Gerstein e Michael Snyder. RNA-Seq: a revolutionary tool for transcriptomics. Nature reviews. Genetics, 10(1):57-63. ISSN 1471-0064. doi: 10.1038/ nrg2484. Citado na pág. 8

Watts e Strogatz(1998) D. J. Watts e S. H. Strogatz. Collective dynamics of small-world networks. Nature, 393:440-442. doi: 10.1038/30918. Citado na pág. 4, 5, 25, 36

Webb e Copsey(2011) Andrew R Webb e Keith D. Copsey. Statistical Pattern Recognition. John Wiley and Sons Ltd, United Kingdom. ISBN 9780470682272. Citado na pág. 18, 19

Werhli e Husmeier(2008) Adriano V. Werhli e Dirk Husmeier. Gene regulatory network reconstruction by bayesian integration of prior knowledge and/or different experimental conditions. Journal of Bioinformatics and Computational Biology, 6(3):543-572. doi: 10.1142/ S0219720008003539. Citado na pág. 26 
Yilmaz et al.(2011) Alper Yilmaz, Maria Katherine Mejia-Guerra, Kyle Kurz, Xiaoyu Liang, Lonnie Welch e Erich Grotewold. Agris: the arabidopsis gene regulatory information server, an update. Nucleic Acids Research, 39(suppl 1):D1118-D1122. doi: 10.1093/nar/gkq1120. Citado na pág. 40,55

Yu et al.(2008) Le Yu, Steven Watterson, Stephen Marshall e Peter Ghazal. Inferring Boolean networks with perturbation from sparse gene expression data: a general model applied to the interferon regulatory network. Molecular bioSystems, 4(10):1024-30. ISSN 1742-2051. doi: 10. 1039/b804649b. Citado na pág. 23

Zhang et al.(2006) Yuping Zhang, Minping Qian, Qi Ouyang, Minghua Deng, Fangting Li e Chao Tang. Stochastic model of yeast cell-cycle network. Physica D: Nonlinear Phenomena, 219(1):35 - 39. ISSN 0167-2789. doi: http://dx.doi.org/10.1016/j.physd.2006.05.009. Citado na pág. 14

Zhao et al.(2013) Haijie Zhao et al. Self-organizing Ising model of artificial financial markets with small-world network topology. EPL (Europhysics Letters), 101(1):18001. ISSN 0295-5075. doi: 10.1209/0295-5075/101/18001. Citado na pág. 25 


\section{Índice Remissivo}

Arabidopsis thaliana, 5, 40, 41, 52, 58

bacia de atração, 13

biologia sistêmica, 6, 7

biological score, 27

busca sequencial, 19

Caenorhabditis elegans, 9

caminho mínimo, 5, 24, 25, 36, 37, 48, 50

caracterização, 1, 7, 24, 26, 37, 50

CoD, 21

coeficiente de clustering, 25, 36, 37, 48, 50, 51, informação mútua, 21, 23

58

componente celular, 10

correlação, 20

DAG, 3, 10, 34, 56, 57

dimensionalidade,redução, 18

directed acyclic graph, 3, 10, 34, 56, 57

DNA, 1, 3-5, 7, 8, 10, 27, 29, 40, 56, 59

Drosophila melanogaster, 9

duplo-híbrido, 9

entropia

entropia de Boltzmann-Gibbs, 21

entropia condicional média, 5, 6, 22, 23, 30, $31,37-39,41,55,58,61$

entropia de Shannon, 21

Escherichia coli, 10, 25

escore biológico, 27

estado do sistema, 12

expressão gênica, 1, 2

extração de características, 37

fator de transcrição, 1, 8, 20, 33

função critério

MCE-SW, 5, 37, 38 função de transição, 14, 16

função molecular, 10

funções booleanas, 12

GenBank, 26

Gene Ontology, 10, 26

GO, 10

gold standard, 40-42, 50, 52, 53, 56, 60, 61

grafo, 10,12

grafo acíclico dirigido, $3,10,34,56,57$

KEGG, 9, 26, 27, 34, 35, 41, 44-46, 48

levedura, 9

maldição da dimensionalidade, 3, 18, 23, 26

Markov, cadeia, 16

matriz de adjacências, 5, 12, 25

microarray, 8

motif de rede, 11

mRNA, 1

network motif, 11

padrão, veja reconhecimento de padrões, 18

Pearson, correlação, 20

penalização, função critério, 23

PGN, 6, 16, 17, 20, 36

Plasmodium falciparum, 5, 33, 34, 40, 41, 53

PPI, 4, 8-10, 25, 30-33, 42-46, 55, 56, 59, 60

processamento de sinais genômicos, GSP, 1

processo celular, 10

proteína, 1, 3-5, 7, 8, 10, 11, 16, 27, 28, 33, 34, 43,55

reconhecimento de padrões, 18

redes booleanas, 12 
redes complexas, 4,10

redução de dimensionalidade, 18

representação de redes, 10

REVEAL, 23

RNA-Seq, 8

Rosetta Stone Fusion Proteins, 5, 10, 27, 29, 33, $35,44-46$

Saccharomyces cerevisiae, 9, 28

SAGE, 8

SBS, 19

scale-free, 26, 33

seleção de características, 7, 17, 18, 30, 31, 38

Serial Analysis of Gene Expression, 8

SFFS, 19

SFFS-BS, 30, 31, 42, 55

SFFS-SW, 36, 38, 39, 48-52, 57, 58

SFS, 19

Shannon, 21

small-world, 5, 25, 36, 57, 62

Spearman, veja correlação, 20

topologia, 24, 25

trajetória, 25, 39, 50-52 